BARBARA CRISTINA GAGLIANO REZENDE

Estudo da Resistência a Múltiplas Drogas no Linfoma Canino 


\section{Estudo da Resistência a Múltiplas Drogas no Linfoma Canino}

Dissertação apresentada ao Programa de Pósgraduação em Clínica Veterinária da Faculdade de Medicina Veterinária e Zootecnia da Universidade de São Paulo para obtenção do título de Mestre em Medicina Veterinária

\section{Departamento:}

Clínica Médica

Área de concentração:

Clínica Veterinária

\section{Orientador:}

Profa. Dra. Sílvia Regina Ricci Lucas 
Autorizo a reprodução parcial ou total desta obra, para fins acadêmicos, desde que citada a fonte.

DADOS INTERNACIONAIS DE CATALOGAÇÃO-NA-PUBLICAÇÃO

(Biblioteca da Faculdade de Medicina Veterinária e Zootecnia da Universidade de São Paulo)

T. 1459 Rezende, Barbara Cristina Gagliano

FMVZ Estudo da resistência a múltiplas drogas no linfoma canino / Barbara Cristina Gagliano Rezende - São Paulo : B. C. G. Rezende, 2005.

$121 \mathrm{f}$ : : il.

Dissertação (mestrado) - Universidade de São Paulo. Faculdade de Medicina Veterinária e Zootecnia. Departamento de Clínica Médica, 2005.

Programa de Pós-graduação: Clínica Veterinária.

Área de concentração: Clínica Veterinária.

Orientador: Profa. Dra. Sílvia Regina Ricci Lucas.

1. Cães. 2. Linfoma. 3. Quimioterapia. 4. Resistência a múltiplas drogas. I. Título. 


\section{UNIVERSIDADE DE SÃO PAULO \\ Faculdade de Medicina Veterinária e Zootecnia \\ Cidade Universitária "Armando de Salles Oliveira" \\ Comissão Bioética \\ CERTIFICADO}

Certificamos que o Projeto intitulado "Avaliação da resistência terapêutica à múltiplas drogas em casos de linfoma na espécie canina", Protocolo $n^{0} 363 / 2003$, utilizando 15 cães, sob a responsabilidade da Prof ${ }^{a}$ Dra $^{a}$ Silvia Regina Ricci Lucas, está de acordo com os princípios éticos de experimentação animal da Comissão de Bioética da Faculdade de Medicina Veterinária e Zootecnia da Universidade de São Paulo e foi aprovado pela referida Comissão, em sessão do dia 10 de março de 2004.

(We certify that the Research "Evaluation of multiple drug resistance in canine lymphoma" protocol number 363/2003, utilizing 15 dogs, under the responsibility of Prof. Dr. Silvia Regina Ricci Lucas, agree with Ethical Principles in Animal Research adopted by Bioethic Commission of the Faculty of Veterinary Medicine and Zootechny of University of São Paulo and was approved in 03/10/2004 meeting.

São Paulo, 10 de março de 2004

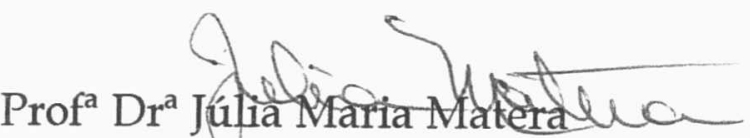

Presidente da Comissão de Bioética

FMVZ/USP 


\section{FOLHA DE AVALIAÇÃO}

Nome do autor: REZENDE, Barbara Cristina Gagliano

Título: Estudo da Resistência a Múltiplas Drogas no Linfoma Canino

Dissertação apresentada ao Programa de Pósgraduação em Clínica Veterinária da Faculdade de Medicina Veterinária e Zootecnia da Universidade de São Paulo para obtenção do título de Mestre em Medicina Veterinária

Data:

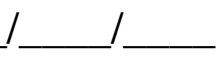

Banca Examinadora

Prof. Dr.

Instituição:

Assinatura:

Julgamento:

Prof. Dr.

Instituição:

Assinatura: Julgamento:

Prof. Dr. Instituição:

Assinatura: Julgamento: 
Aos meus pais Myriam e Ronaldo pelo infinito amor, educação e confiança

Ao meu noivo Paulo pelo constante companheirismo, entusiasmo e amor

A minha eterna Barbie (in memorian) pelos inesquecíveis momentos de felicidade e sinceridade

A todos os cães do estudo por colaborarem com a evolução da Ciência tanto na Medicina Veterinária quanto na Medicina Humana 
A Deus por me sustentar em todas as situações.

A minha orientadora Profa. Dra. Sílvia Regina Ricci Lucas por toda confiança, a qual, permitiu com muita liberalidade e originalidade a condução deste trabalho. Nossos vínculos foram além de uma desejável relação orientador-orientado.

Ao Prof. Dr. Sérgio Paulo Bydlowski pela consistente co-orientação, solicitude, amabilidade e por ter disponibilizado o laboratório de Hematologia Molecular LIM-31, FMUSP, imprescindível para a realização deste estudo.

À grande amiga Débora Levy, por suas infinitas e essenciais contribuições que permitiram o desenvolvimento e execução deste trabalho. Diante de tantas adversidades, Débora Levy nunca hesitou em superá-las. Agradeço a Deus por me presentear com esta pessoa única e tão virtuosa.

Aos queridos professores do Depto. de Patologia, Dra. Maria Lúcia Zaidan Dagli e Dr. José Luís Guerra por me ensinarem com muito entusiasmo as primícias da Oncologia Veterinária, pela constante confiança e por todo carinho.

À Adriana de Aguiar Debes por todo auxílio prestado e pelos preciosos ensinamentos.

À Luciana Morganti Ferreira Maselli pelo companheirismo, carinho e pela notável boa vontade.

À Regina Maria Feitosa Gil por sua incansável gentileza e pelas boas conversas.

Aos colegas de laboratório Andréia, Fernando e Paulo pelos bons e divertidos momentos.

Ao meu grande amigo e colega Francisco Manuel Moreno Carmona, pelo constante incentivo para a minha constituição como pesquisadora, principalmente nos momentos mais árduos. Agradeço ainda sua infinita sinceridade, companheirismo e amor. 
Ao colega de pós-graduação Alexandre Merlo pelos grandes conselhos na área de Clínica e pelas palavras amigas nas horas difíceis.

Aos médicos veterinários contratados e residentes do Serviço de Clínica Médica do HOVET-FMVZ/USP, pelo auxílio no atendimento dos casos clínicos e pela boa vontade.

Aos enfermeiros do Serviço de Clínica Médica do HOVET-FMVZ/USP, em especial ao Gilberto ou melhor Giba, pelas exaustivas, porém agradáveis horas de trabalho conjunto.

À M.V. Maria Luiza Fhanchini e aos demais funcionários do laboratório de Hematologia Clínica do HOVET-FMVZ/USP, pela eficácia na execução dos exames.

À funcionária Creide Donizete Soares pela agilidade na liberação dos resultados dos exames e pela constante boa vontade.

À FAPESP pelo apoio financeiro, sem o qual, este trabalho não poderia ser realizado.

À CAPES pela concessão da bolsa de mestrado, pelo processo 0224/2003.

Ao Serviço de Transplante de Medula Óssea do Hospital Dia da Fundação PróSangue-Hemocentro, FMUSP, em especial ao funcionário Landri, por ter disponibilizado negatoscópios para reprodução fotográfica dos géis de poliacrilamida.

Enfim, a todas as pessoas que de forma direta ou indireta, contribuíram com o desenvolvimento deste trabalho, a minha formação como pesquisadora e ser humano, meus sinceros agradecimentos. 


\section{RESUMO}

REZENDE, B. C. G. Estudo da Resistência a Múltiplas Drogas no Linfoma Canino. [Study of multiple drug resistance in canine lymphoma]. 2005. 121f. Dissertação (Mestrado em Medicina Veterinária) - Faculdade de Medicina Veterinária e Zootecnia, Universidade de São Paulo, São Paulo, 2005.

Uma das causas mais freqüentes de insucesso terapêutico do câncer, está associada à Resistência a Múltiplas Drogas (MDR). A resistência a múltiplas drogas refere-se ao desenvolvimento de resistência simultânea a uma variedade de agentes citotóxicos que apresentam diferentes sítios de ação e estruturas químicas diversas. Os mecanismos MDR são representados por genes cujos produtos funcionam como bombas, reduzindo o acúmulo intracelular de drogas e a resposta ao tratamento. $\mathrm{O}$ linfoma é uma neoplasia comum na espécie, sendo muito responsiva à quimioterapia, embora a recidiva seja esperada e possa estar relacionada ao MDR. O presente estudo teve como objetivo avaliar a expressão dos genes MDR-1, MRP e LRP e de seus produtos, em cães com linfoma. Foram colhidas amostras de linfonodos periféricos de 15 cães com linfoma multicêntrico ao diagnóstico e na recidiva (durante a quimioterapia). A expressão dos genes e proteínas MDR foram determinados por RT-PCR e "Dot Blotting", respectivamente. As freqüências de expressão ao diagnóstico dos genes MDR, MRP e LRP foram 93,3\% igualmente e as freqüências de seus produtos foram $85,8 \% ; 71,5 \%$ e $85,8 \%$ respectivamente. $\mathrm{Na}$ recidiva, as freqüências de expressão dos genes MDR, MRP e LRP elevaram-se para 100\% igualmente e as freqüências de suas proteínas foram 92,9\% para P-gp e MRP e de $100 \%$ para LRP. Portanto, obteve-se uma alta freqüência na expressão do MDR-1/P-gp, MRP e LRP, em quase todos os cães, não só na recidiva, como também ao diagnóstico. É necessário verificar se estes mecanismos podem induzir o 
fenótipo MDR no linfoma canino multicêntrico. O estudo dos mecanismos MDR trará novas perspectivas para o tratamento de tumores como o linfoma canino. A modulação desses mecanismos por meio de drogas específicas ou por terapia gênica, pode contribuir para o sucesso do tratamento de neoplasias caninas ou humanas.

Palavras-chave: Cães. Linfoma. Quimioterapia. Resistência a Múltiplas Drogas. 


\begin{abstract}
REZENDE, B .C. G. Study of Multiple Drug Resistance in Canine Lymphoma. [Estudo da resistência a múltiplas drogas no linfoma canino].121 f. 2005. Dissertação (Mestrado em Medicina Veterinária) - Faculdade de Medicina Veterinária e Zootecnia, Universidade de São Paulo, São Paulo, 2005.
\end{abstract}

One of the most frequent causes of treatment failure in cancer is associated to Multiple Drug Resistance (MDR). MDR refers to simultaneous resistance to a variety of cytotoxic agents that have different targets and diversal chemical structures. MDR mechanisms are represented by genes wich encodes proteins that work like pumps, reducing intracellular drug acumulation and the response to treatment. Lymphoma is a common neoplasia in dogs wich is very responsive to chemotherapy, although relapses are expected, including those related to MDR. The aim of this study was to evaluate the possible expression of MDR-1, MRP and LRP genes and their proteins, in dogs with lymphoma. Lymph node samples at diagnosis and at relapse (during chemotherapy) from 15 dogs with multicentric lymphoma were obtained. The expression of MDR genes and proteins were determined by RT-PCR and Dot Blotting. Expression of MDR, MRP and LRP gene were 93,3\% at diagnosis and their products were $85,8 \% ; 71,5 \%$ and $85,8 \%$ respectively. Expression of MDR, MRP and LRP gene increased to $100 \%$ at relapse and their proteins were $92,9 \%$ to P-gp and MRP and 100\% to LRP. High frequency of MDR-1/P-gp, MRP and LRP expressions were found in almost all dogs, not only at relapse but also at diagnosis. It's necessary to analyse if these mechanisms can induce the MDR fenotype in canine multicentric lymphoma. The study of MDR mechanisms will conduct the treatment of tumors like canine lymphoma to new perspectives. The modulation of these mechanisms by 
certain drugs or gene therapy, may contribute to the success in treatment of canine or human neoplasias.

Key-words: Dogs. Lymphoma. Chemotherapy. Multiple Drug Resistance. 


\section{LISTA DE FIGURAS}

Figura 2.1 - Estrutura da Glicoproteína - P.... .30

Figura 2.2 - $\quad$ Estrutura da Proteína MRP 39

Figura $2.3-$ Complexo "Vault" em microscopia eletrônica (A); em desenho (B) 44

Figura 4.1 Eletroforese em gel de agarose 1\% corado com brometo de etídio dos RNAs totais de cães com linfoma multicêntrico ao diagnóstico $(A)$ e na recidiva $(P)$. 72

Figura 4.2 Curva padrão típica de dosagem de proteína pelo método Lowry 74

Figura 4.3 - $\quad$ Curva de temperaturas de anelamento para reação de RT-PCR de MDR$1 \mathrm{em}$ gel de agarose $2 \%$ corado com brometo de etídio (PM: padrão de peso molecular; 1: $50^{\circ} \mathrm{C}$; $2: 50,4^{\circ} \mathrm{C} ; 3: 51,2^{\circ} \mathrm{C} ; 4: 52,5^{\circ} \mathrm{C} ; \mathbf{5}: 53,2^{\circ} \mathrm{C} ; 6$ : $\left.54,6^{\circ} \mathrm{C} ; 7: 55^{\circ} \mathrm{C} ; 8: 55,8^{\circ} \mathrm{C} ; 9: 56,4^{\circ} \mathrm{C} ; 10: 57,8^{\circ} \mathrm{C} ; 11: 58,9^{\circ} \mathrm{C} ; 12: 60^{\circ} \mathrm{C}\right)$ de cão com linfoma multicêntrico 76

Figura 4.4 -

Eletroforese em gel de poliacrilamida a $6 \%$ corado com prata da reação de RT-PCR para detecção do gene MDR-1em cães com linfoma multicêntrico. PM: padrão de peso molecular de 100bp; A: previamente a quimioterapia; P: recidiva do linfoma.

Figura 4.5 - Titulação do anticorpo primário anti-Pgp 78

Figura 4.6 -

"Slot Dot" anti-Pgp em membrana de PVDF em cães com linfoma multicêntrico. A: previamente a quimioterapia; P: recidiva do linfoma; SC: sarcoma uterino resistente à doxorrubicina.

Figura 4.7 - $\quad$ Eletroforese em gel de poliacrilamida a 6\% corado com prata da reação de RT-PCR para detecção do gene MRP em cães com linfoma multicêntrico. PM: padrão de peso molecular de 100bp; A: previamente a quimioterapia; P: recidiva do linfoma. 80

Figura 4.8 Titulação do anticorpo primário anti-MRP. .81

Figura 4.9 -

"Slot Dot"anti-MRP em membrana de PVDF de cães com linfoma multicêntrico. A: previamente a quimioterapia; P: recidiva do linfoma; SC: sarcoma uterino resistente à doxorrubicina. 
Figura 4.10 -

Curva de temperaturas de anelamento para reação de RT-PCR para detecção do gene LRP em cão com linfoma multicêntrico, em gel de poliacrilamida $6 \%$ corado com prata. PM: padrão de peso molecular de 100bp; 1: $51,2^{\circ} \mathrm{C} ; 2: 51,4^{\circ} \mathrm{C} ; 3: 51,6^{\circ} \mathrm{C} ; 4: 51,8^{\circ} \mathrm{C} ; \mathbf{5}: 52^{\circ} \mathrm{C} ; 6: 52,2^{\circ} \mathrm{C} ; 7:$ $52,4^{\circ} \mathrm{C} ; 8: 52,6^{\circ} \mathrm{C} ; 9: 52,8^{\circ} \mathrm{C}$ e $10: 53^{\circ} \mathrm{C}$

Figura 4.11 - Eletroforese em gel de poliacrilamida a 6\% corado com prata da reação de RT-PCR para detecção do gene LRP em cães com linfoma multicêntrico. PM: padrão de peso molecular de 100bp; A: previamente a quimioterapia; P: recidiva do linfoma. 83

Figura 4.12 - Titulação do anticorpo primário anti-LRP 84

Figura 4.13 - "Slot Dot" anti-LRP em membrana de PVDF de cães com linfoma multicêntrico. A: previamente a quimioterapia; P: recidiva do linfoma; SC: sarcoma uterino resistente à doxorrubicina.

Figura 4.14 - Curva de temperaturas de anelamento para reação de RT-PCR de DOG $\beta_{2}$-microglobulina em gel de agarose $2 \%$ corado com brometo de etídio(PM: padrão de peso molecular; 1: $50^{\circ} \mathrm{C} ; 2$ : $50,4^{\circ} \mathrm{C} ; 3$ : $51,2^{\circ} \mathrm{C}$; 4: 52,5 $5^{\circ} \mathrm{C}$; 5: $54,2^{\circ} \mathrm{C} ; 6: 56,4^{\circ} \mathrm{C} ; 7: 58,9^{\circ} \mathrm{C} ; 8: 51^{\circ} \mathrm{C} ; 9: 62,7^{\circ} \mathrm{C} ; 10: 63,9^{\circ} \mathrm{C}$; 11: $64,7^{\circ} \mathrm{C} ; 12: 65^{\circ} \mathrm{C}$ ) em cão com linfoma multicêntrico 86

Figura 4.15 - $\quad$ Eletroforese em gel de poliacrilamida a 6\% corado com prata da reação de RT-PCR para detecção do gene $D O G \beta_{2}$-microglobulina em cães com linfoma multicêntrico. PM: padrão de peso molecular de 100bp; A: previamente a quimioterapia; $\mathbf{P}$ : recidiva do linfoma 


\section{LISTA DE QUADROS}

Quadro 3.1 - Esquema do protocolo quimioterápico COP, utilizado em 9 cães do estudo, no Serviço de Clínica Médica - HOVET da FMVZ-USP, São Paulo - março/03 a setembro/04. .59

Quadro 3.2 - Esquema do protocolo quimioterápico VCM, utilizado em 6 cães do estudo, no Serviço de Clínica Médica - HOVET da FMVZ-USP, São Paulo-março/03 a setembro/04. 60

Quadro 4.1 - Caracterização dos cães com linfoma multicêntrico segundo identificação (ID), definição racial, idade, sexo, classificação citológica segundo "Working Formulation" (1982), estadio, protocolo quimioterápico (PROT), início da quimioterapia (QT), tipo de remissão (Remissão 1), duração da remissão (Remissão 2), recidiva e sobrevida, atendidos no HOVETFMVZ/USP, São Paulo - no período de março/03 setembro/04. 71

Quadro 4.2 - Distribuição do RNAs amostrais de 15 cães com linfoma multicêntrico, segundo concentração ([ ]) em $\mu \mathrm{g} / \mathrm{ml}$, absorbância (ABS), pureza (\%) e razão (R). Laboratório de Hematologia Molecular, LIM-31, FMUSP, São Paulo - março/03 a setembro/04...................................................73

Quadro 4.3 - Distribuição das amostras de 15 cães com linfoma multicêntrico, segundo as concentrações proteicas mensuradas em duplicata ([x1] e [x2]) e o valor médio ([xM]) por espectrofotômetro, pelo método de Lowry. Laboratório de Hematologia Molecular, LIM-31, FMUSP, São Paulo março/03 a setembro/04

Quadro 4.4 - $\quad$ Distribuição das amostras de 15 cães com linfoma multicêntrico, segundo positividade ou negatividade para o gene MDR-1, P-gp, gene MRP (MRPG), proteína MRP (MRP-P), gene LRP (LRP-G) e proteína LRP (LRPP).Laboratório de Hematologia Molecular, LIM-31, FMUSP, São Paulo março/03 a setembro/04.

Quadro A.1 - $\quad$ Caracterização dos cães com linfoma multicêntrico segundo identificação (ID), $\mathrm{N}^{\circ}$ de Hemáceas $(\mathrm{He})$, Hematócrito $(\mathrm{Ht})$, Hemoglobulina $(\mathrm{Hb}), \mathrm{VCM}$, HCM, CHCM, No de plaquetas (Plaq), No de Leucócitos (Le), Neutrófilos $(N)$, Eosinófilos $(E)$, Basófilos (B), Linfócitos Típicos (LT), Linfócitos Atípicos (LA), Monócitos (M)ao diagnóstico, atendidos no HOVETFMVZ/USP, São Paulo - no período de março/03-setembro/04 ............115 
Quadro A.2 - Caracterização dos cães com linfoma multicêntrico segundo identificação (ID), Uréia (U), Creatinina (C), Proteínas Totais (Pt), Albumina (ALB), Alanina Aminotransferase (ALT), Fosfatase Alcalina (FA), Cálcio ( $\mathrm{Ca})$ e Fósforo (P), ao diagnóstico, atendidos no HOVETFMVZ/USP, São Paulo - no período de março/03-setembro/04

Quadro A.3 - Cães com linfoma multicêntrico segundo identificação (ID), Odor, Aspecto, Cor, pH, Densidade e Observações encontradas na urina, ao diagnóstico, atendidos no HOVET-FMVZ/USP, São Paulo - no período de março/03-setembro/04. 118

Quadro A.4 - Caracterização dos cães com linfoma multicêntrico segundo identificação (ID), radiografia torácica (RX) e ultra-sonografia abdominal (US), atendidos no HOVET-FMVZ/USP, ao diagnóstico, São Paulo - no período de março/03-setembro/04 


\section{LISTA DE TABELA}

Tabela 4.1 - Distribuição da freqüências de expressão para o gene MDR-1, P-gp, gene MRP, proteína MRP, gene LRP e proteína LRP, ao diagnóstico, na recidiva e adquirida, em 15 cães com linfoma multicêntrico. Laboratório de Hematologia Molecular, LIM-31, FMUSP , São Paulo - março/03 a

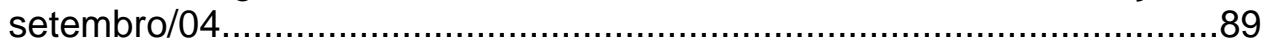




\section{LISTA DE ABREVIATURAS E SIGLAS}

A base nucleotídica adenina

ABC família das proteínas transportadoras $A B C$

ADP difosfato de adenosina

AIDS síndrome da imunodeficiência adquirida

ALT alanina aminotransferase

AST aspartato aminotrasferase

ATP trifosfato de adenosina

AZTMP azidotimidina monofosfato

BCL-2 gene supressor de apoptose

BCRP-1 proteína de resistência de câncer de mama

BSA soro albumina bovina

C base nucleotídica citosina

cDNA DNA complementar

cm centímetro

DEPC dietil pirocarbonato

DNA ácido dessóxirribonucleico

DTT ditiotreitol

EDTA ácido dietilenodiaminotetracético

EGTA ácido etileno glicol-bis ( $\beta$ - aminoetil-eter)- $\mathrm{N}$ - N- N- N-tetracético

FA fosfatase alcalina

$\mathrm{fL} \quad$ fentolitro

G base nucleotídica guanina

g grama

g/dL grama por decilitro

GSH glutationa

GST glutationa-S-transferase 


\begin{tabular}{|c|c|}
\hline im & intramuscular \\
\hline kB & fator nuclear envolvido na transcrição do gene MDR-1 \\
\hline Kda & quilodálton \\
\hline LRP & gene ou proteína relacionada à resistência de pulmão \\
\hline$M^{2}$ & metro quadrado \\
\hline Mda & megadálton \\
\hline MDR & resistência a múltiplas drogas \\
\hline MDR-1 & principal gene de resistência a múltiplas drogas \\
\hline $\mathrm{mg}$ & miligrama \\
\hline $\mathrm{mg} / \mathrm{dL}$ & miligrama por decilitro \\
\hline MGMT & $\mathrm{O}^{6}$ - metilguanina- DNA- metiltransferase \\
\hline $\mathrm{MH}_{\mathrm{z}}$ & megahertz \\
\hline $\mathrm{mL}$ & mililitro \\
\hline$\mu \mathrm{L}$ & microlitro \\
\hline $\mathrm{mm}$ & milímetro \\
\hline $\mathrm{mm}^{3}$ & milímetro cúbico \\
\hline $\mathrm{mM}$ & milimol \\
\hline MRP & gene ou proteína associada a múltiplas drogas \\
\hline MRP-1 & principal proteína associada a múltiplas drogas \\
\hline MVP & principal proteína do complexo "vault" \\
\hline NAD & nicotinamida adenina dinucleotídeo \\
\hline NF-IL 6 & fator de transcrição do gene MDR-1 \\
\hline $\mathrm{nm}$ & nanômetro \\
\hline $\mathrm{N}$ - terminal & extremidade amino $\left(\mathrm{NH}_{2}\right)$ de uma cadeia peptídica \\
\hline $\mathrm{O}^{6}-\mathrm{AT}$ & $\mathrm{O}^{6}-$ aquilguanina- DNA- transferase \\
\hline OMS & Organização Mundial da Saúde \\
\hline P193 & proteína de 193 Kda do complexo "vault" \\
\hline P240 & proteína de 240 Kda do complexo "vault" \\
\hline
\end{tabular}




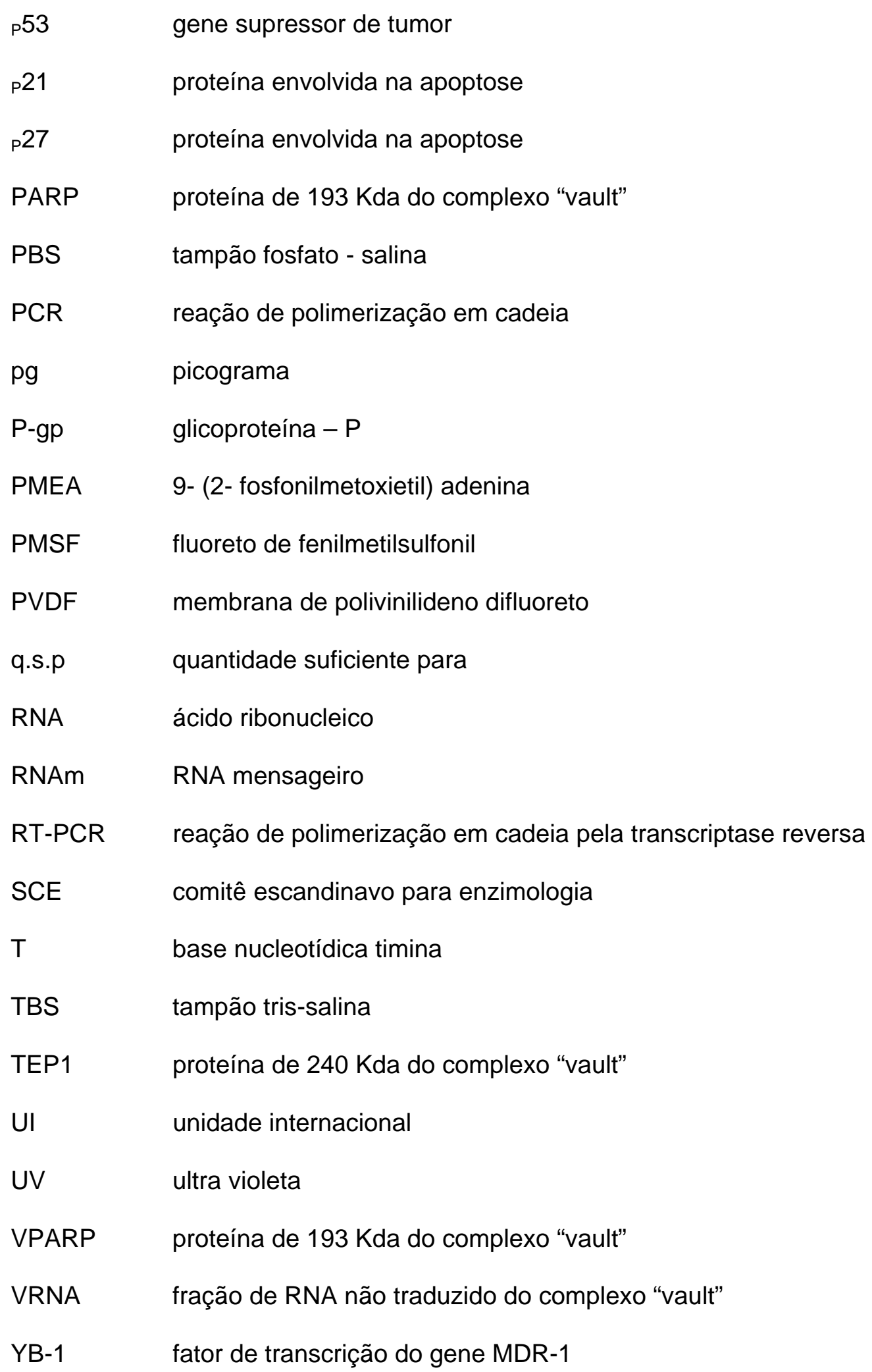




\section{LISTA DE SÍMBOLOS}

$\begin{array}{ll}\alpha & \text { alfa } \\ \% & \text { porcentagem } \\ { }^{\circ} \mathrm{C} & \text { graus Celsius } \\ \beta & \text { beta } \\ \mathrm{DOG}_{2} & \beta_{2} \text {-microglobulina canina } \\ + & \text { positivo } \\ - & \text { negativo }\end{array}$




\section{SUMÁRIO}

1 INTRODUÇÃO 23

2 REVISÃO DE LITERATURA. .25

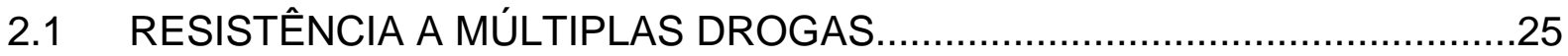

2.2 GENE DE RESISTÊNCIA A MÚLTIPLAS DROGAS (MDR-1) e GLICOPROTEÍNA - P (P-gp)

2.3 PROTEÍNA ASSOCIADA À RESISTÊNCIA A MÚLTIPLAS DROGAS (MRP). .38

2.4 PROTEÍNA RELACIONADA À RESISTÊNCIA DE PULMÃO (LRP). 43

2.5 RESISTÊNCIA A MÚLTIPLAS DROGAS E LINFOMA CANINO MULTICÊNTRICO.

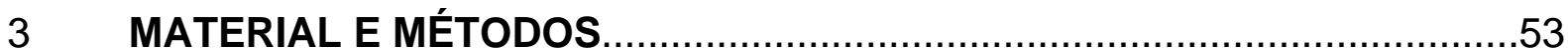

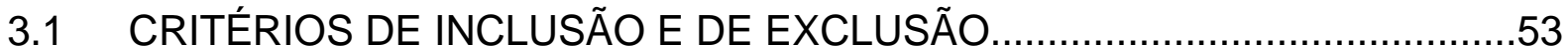

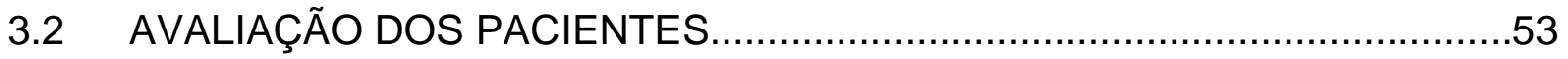

3.3 EXAMES COMPLEMENTARES..................................................................................

3.3.1 Hemograma

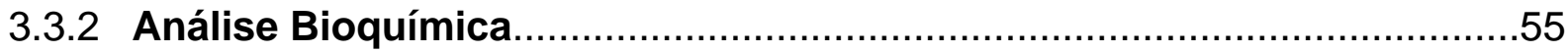

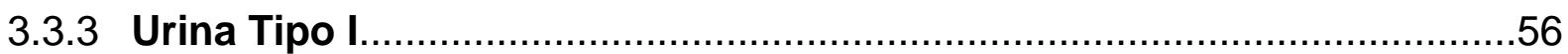

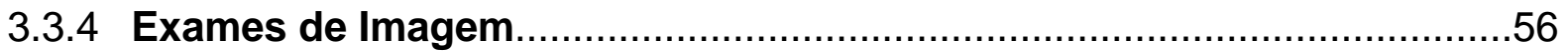

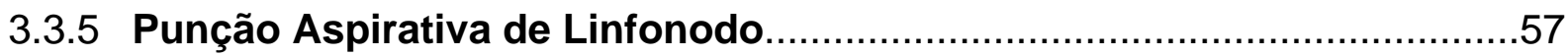

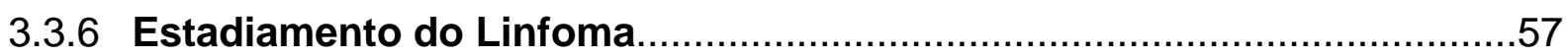

3.4 TRATAMENTO

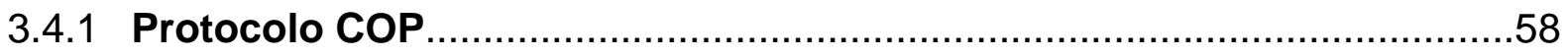

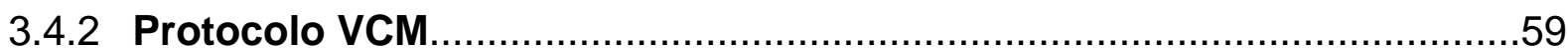

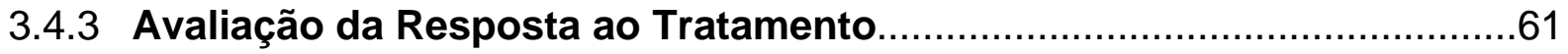

3.5 ANÁLISE DA RESISTÊNCIA A MÚLTIPLAS DROGAS POR BIOLOGIA

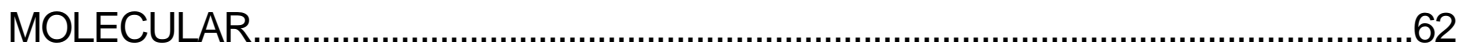

3.5.1 Conservação e Preparo do Material Analisado....................................................62

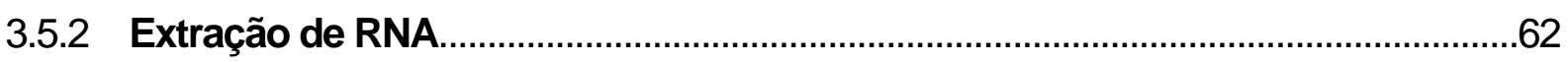

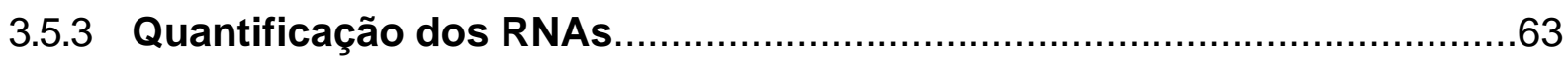

3.5.4 Estudo da Expressão do Gene MDR-1 por RT-PCR ……......................63 
3.5.5 Estudo da Expressão do Gene MRP por RT-PCR. 64

3.5.6 Estudo da Expressão do Gene LRP por RT-PCR. .65

3.5.7 Estudo da Expressão do Gene $\beta_{2}$-microglobulina Canina por RTPCR.

3.5.8 Conservação das Proteínas. 67

3.5.9 Determinação da Concentração das Proteínas. .67

3.5.10 Estudo da Expressão das Proteínas P-GP, MRP-1 E LRP POR "DOT BLOT"

4 RESULTADOS 70

4.1 CASUÍSTICA 70

4.2 ANÁLISE DA RESISTÊNCIA A MÚLTIPLAS DROGAS POR BIOLOGIA MOLECULAR. .72

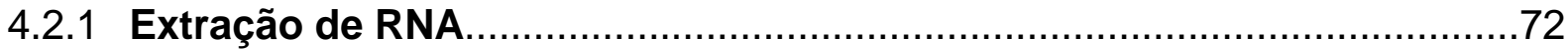

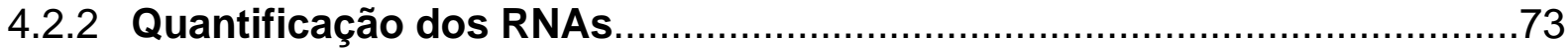

4.2.3 Determinação da Concentração das Proteínas...................................74

4.2.4 Estudo da Expressão do Gene MDR-1 .............................................. 76

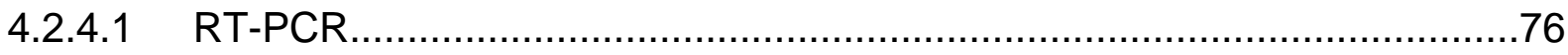

4.2.4.2 Expressão da P-gp por "Dot Blot"..............................................78

4.2.5 Estudo da Expressão do Gene MRP ............................................... 79

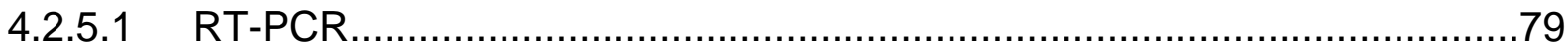

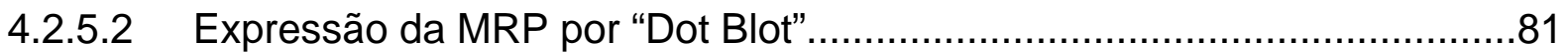

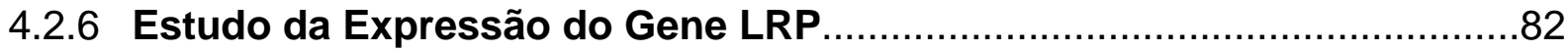

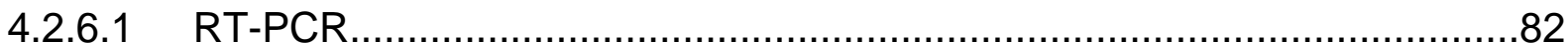

4.2.6.2 Expressão da LRP por "Dot Blot" ............................................... 84

4.2.7 Estudo da Expressão do Gene $\beta_{2}$-microglobulina Canina.......................85

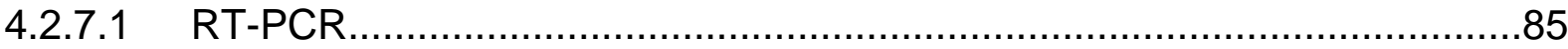

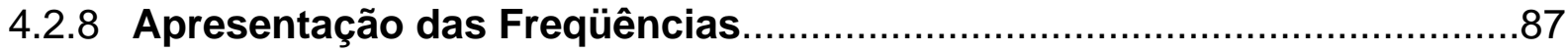

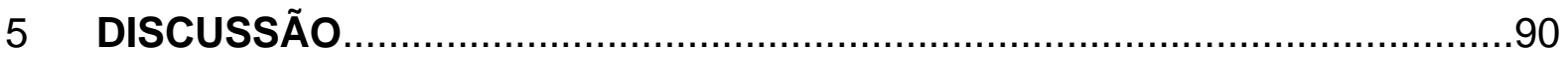

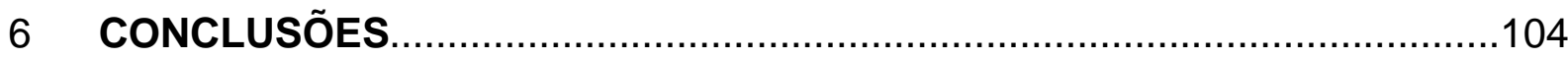

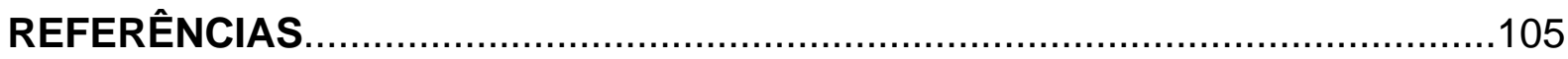

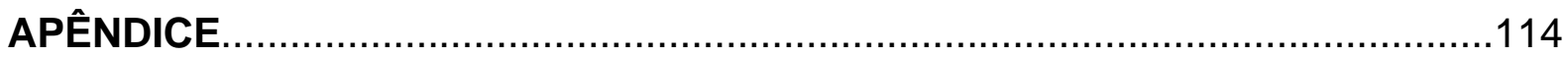




\section{INTRODUÇÃO}

O desenvolvimento da Medicina Veterinária na área de Clínica de Pequenos Animais, nos últimos 20 anos, vem permitindo a melhora significativa da qualidade de vida dos animais de estimação, graças a medidas como nutrição balanceada, vermifugações e imunizações periódicas, tratamento periodontal regular, dentre outros. Em conseqüência dessa melhora na condição de vida, os pequenos animais atingem idades mais avançadas.

Paralelamente ao aumento da longevidade, a prevalência de neoplasias também se eleva nesses animais, de maneira a constituir a primeira causa de morte na espécie canina atualmente, segundo a literatura internacional.

Dentre todas as neoplasias caninas, os tumores de pele são os mais freqüentes, seguido pelos neoplasmas de mama e pelo linfoma multicêntrico respectivamente. A alta freqüência do linfoma canino multicêntrico levou a realização de diversos estudos, principalmente no que se refere à conduta terapêutica.

O tratamento eletivo para o linfoma multicêntrico canino baseia-se na quimioterapia multimodal. A maioria dos cães responde bem à terapia de indução, entretanto, as recidivas são freqüentes durante o período de manutenção da remissão. Neste momento, a quimioterapia com fármacos até mesmo diferentes daqueles utilizados inicialmente não produzem mais resposta. Cogita-se que este fato possa estar relacionado ao fenômeno denominado Resistência a Múltiplas Drogas (MDR), a exemplo do que ocorre em seres humanos.

A resistência a múltiplas drogas pode ser definida como resistência simultânea a uma variedade de agentes citotóxicos que apresentam diferentes sítios de ação e estruturas químicas diversas. 
Existem vários mecanismos que induzem à resistência a múltiplas drogas dentre os quais, pode-se citar os que ocasionam o efluxo de drogas para o meio extracelular. Assim, os agentes citotóxicos não vão atuar, uma vez que seus sítios de ação encontram-se no meio intracelular, como citoplasma e núcleo.

Os mecanismos que atuam nesse sentido são representados pelos genes MDR-1, MRP, LRP e pelas proteínas P-gp, MRP e LRP respectivamente. O estudo desses mecanismos pode contribuir sobremaneira na conduta terapêutica do linfoma multicêntrico em cães, trazendo novas perspectivas. Assim como observado na Medicina Humana, drogas ou até mesmo terapias gênicas que revertam esses mecanismos, se comprovadamente presentes e ativos no linfoma canino, poderão ser cogitadas.

Portanto, o presente estudo teve como objetivo verificar a possível presença e envolvimento desses genes e de seus produtos no momento do diagnóstico e na recidiva do linfoma canino. 


\section{REVISÃO DE LITERATURA}

\subsection{RESISTÊNCIA A MÚLTIPLAS DROGAS}

O uso de agentes quimioterápicos constitui um dos tratamentos eletivos para diversos tumores. Contudo, muitas neoplasias não respondem à quimioterapia e outras, inicialmente responsivas, tornam-se resistentes posteriormente. O desenvolvimento de resistência frente a diferentes agentes antineoplásicos é um obstáculo fundamental para o êxito terapêutico desde o início do uso da quimioterapia no tratamento de tumores. A utilização de múltiplas drogas combinadas determinou um importante avanço para a diminuição no desenvolvimento de resistência, porém, diversos tumores persistem resistentes aos mais diferentes tipos de tratamento farmacológico.

O modelo genético de resistência aos agentes antineoplásicos foi estabelecido por Goldie e Coldman (1979). Esses autores apresentaram um modelo matemático baseado no desenvolvimento de resistência bacteriana, assumindo como causa principal de fracasso terapêutico em Oncologia, a seleção de células resistentes com alterações genéticas, sendo esta resistência proporcional ao número de células tumorais e à freqüência de mutações espontâneas. Esta hipótese levou a duas conclusões importantes: a primeira, com relação ao uso combinado de agentes, já que a seleção de células resistentes a mais de um fármaco seria menos provável; e a segunda, justificando um tratamento mais precoce dos tumores, uma vez que a seleção de células resistentes seria tanto menor quanto menor a massa tumoral.

O fator de maior relevância envolvido no insucesso do tratamento do câncer, portanto, é representado pelo desenvolvimento de resistência a drogas pelas células tumorais (GINN, 1996; KANZAKI et al., 2001; LIU; OHSHIMA; KIKUCHI, 2001). A 
resistência a drogas pode ser definida como a habilidade das células neoplásicas de sobreviverem à exposição a agentes tóxicos em doses máximas toleradas por tecidos normais. A resistência a múltiplas drogas refere-se à resistência simultânea a uma variedade de agentes citotóxicos que apresentam diferentes sítios de ação e estruturas químicas diversas (GINN,1996; RAAIJMAKERS et al., 1998).

A resistência a múltiplas drogas pode constituir-se numa propriedade intrínseca das células tumorais, ou pode ser adquirida por populações destas células que inicialmente são sensíveis à quimioterapia e posteriormente, tornam-se resistentes, com a exposição aos agentes citotóxicos (GINN, 1996; LIU; OHSHIMA; KIKUCHI, 2001).

A inabilidade de tratar pacientes de forma efetiva após a recidiva do tumor deve-se a múltiplos fatores de resistência, estudados há aproximadamente três décadas. Os mecanismos de resistência representam diversas formas de proteção da célula e do organismo e estão presentes na maioria das células normais. Infelizmente, muitos tumores utilizam esses mecanismos para sua própria proteção (BERGMAN, 2003).

Dentre os diversos mecanismos de resistência adquirida, pode-se citar os que ocasionam a redução no acúmulo de drogas como o da glicoproteína-P (P-gp), da proteína associada à resistência a múltiplas drogas (MRP) e aquele da proteína relacionada à resistência resistência de pulmão (LRP). Existem mecanismos que levam a alterações no local de ação das drogas, como as topoisomerases I e II. Essas enzimas catalisam fisiologicamente diversas mudanças conformacionais no DNA. Agentes citotóxicos como as epipodofilotoxinas e antraciclinas inibem a ação da topoisomerase II, levando à morte celular. Se a célula tumoral apresentar 
alterações nas topoisomerases, pode se tornar resistente aos agentes quimioterápicos e não ocorrer morte celular (BERGMAN, 2003).

Ainda em relação aos mecanismos de resistência, existem aqueles que promovem a detoxificação de drogas, inclusive as quimioterápicas, como o sistema glutationa representado pela glutationa-S-transferase (GST) e glutationa (GSH). Observa-se que células tumorais têm sua produção aumentada de GST e GSH quando expostas a drogas como doxorrubicina, clorambucil, ciclofosfamida, nitrosuréias e cisplatina. As enzimas diidrofolato redutase e timidilato sintetase também agem na detoxificação de fármacos (BERGMAN, 2003). Outro mecanismo envolvido no processo de resistência, atua no reparo do DNA. O seu maior representante é a enzima $\mathrm{O}^{6}$-AT $\left(\mathrm{O}^{6}\right.$-alquilguanina-DNA transferase), codificada pelo gene MGMT e que repara danos no DNA induzidos por quimioterápicos como dacarbazina e nitrosuréias (BERGMAN, 2003).

Pode-se ainda citar os que interferem na apoptose. A maioria dos quimioterápicos e a radiação matam as células neoplásicas por indução de apoptose. Infelizmente, as células cancerígenas desenvolvem mecanismos de regulação e/ou ativação dos genes supressores de apoptose. A família BCL-2, o $P_{53}$, $\mathrm{P}_{21}, \mathrm{P}_{27}$ e as caspases parecem estar envolvidos. Observou-se que células tumorais resistentes à apoptose são também resistentes às mais altas doses de agentes quimioterápicos e radioativos (BERGMAN, 2003). 


\subsection{GENE DE RESISTÊNCIA A MÚltiPLAS DROGAS (MDR-1) e GLICOPROTEÍNA - P (P-gp)}

Dentre todos os mecanismos de resistência a múltiplas drogas já descritos, o gene de resistência a múltiplas drogas denominado MDR, que codifica uma proteína de alto peso molecular, a glicoproteína - P (P-gp) é o principal responsável pelo fenômeno MDR e o mais estudado até o momento (BATES, 1999; GINN, 1996; LEE et al., 1996; LIU; OHSHIMA; KIKUCHI, 2001; MOORE et al., 1995).

O gene MDR está presente em bactérias, vírus, plantas, insetos, nematóides e em mamíferos. Esta consenvação evolucionária revela a extrema importância deste gene e da sua proteína (BERGMAN, 2003).

Moléculas de P-gp foram identificadas e implicadas na resistência a drogas em organismos como Leishmania, Plasmodium, além de hamster, camundongos e em cultura de células de cães e de seres humanos (GINN, 1996). Sabe-se que microorganismos como bactérias, fungos e protozoários também possuem mecanismos de resistência a drogas, como aquele mediado pela P-gp, resultando na ausência de resposta ao tratamento medicamentoso (LAGE, 2003).

Em humanos e roedores, a P-gp apresenta múltiplas isoformas codificadas por famílias do gene MDR (MDR-1, MDR-2, MDR-3) (GINN, 1996).

As estruturas íntron-éxon dos genes MDR-1 de seres humanos e de ratos são virtualmente idênticas. A isoforma conhecida em seres humanos por conferir resistência a drogas é codificada pelo gene MDR-1. Este gene, que codifica a P-gp, foi clonado e provouse que confere resistência a células tumorais por meio de estudos nos quais este gene foi detectado num clone de células resistentes a drogas (GINN, 1996). 
Em relação ao se conhece sobre o MDR-1 e a P-gp, o mecanismo mais estudado de resistência a drogas, sabe-se pouco a respeito da regulação deste gene. Diferentes agentes, hormônios, oncogenes e fatores de transcrição podem ser relacionados à modulação da expressão do MDR-1 em seres humanos. Substâncias ou fatores como o butirato de sódio, ácido retinóico, vincristina, gene P53, fator nuclear kB, NF-IL 6 e YB-1 são alguns exemplos (BATES, 1999).

Sabe-se que, em animais expostos experimentalmente a carcinógenos e submetidos a hepatectomia parcial, há indução do MDR-1 no fígado. Hormônios esteroidais induzem a expressão MDR-1 no epitélio secretor do útero. Níveis nucleares de YB-1, um fator de transcrição associado à proliferação celular, podem estar relacionados à expressão do MDR-1 em câncer de mama e osteossarcoma em seres humanos. Portanto, a ativação do MDR-1 pode ser desencadeada por diversos fatores (BATES, 1999).

Dano em 1973, foi o primeiro pesquisador a demonstrar a existência do fenótipo MDR em células de tumor de Erlich. Este autor observou que estas foram capazes de reduzir sua concentração intracelular de daunorrubicina, porém por mecanismo desconhecido.

Juliano e Ling identificaram pela primeira vez, em 1976, uma proteína de transporte que parecia funcionar como uma bomba de efluxo para alguns compostos citotóxicos, em células tumorais que expressavam MDR.

A P-gp funciona como uma bomba de efluxo dependente de energia, que resulta em uma diminuição no acúmulo intracelular de agentes citotóxicos em células tumorais. Estudos envolvendo a estrutura e função desta proteína em vertebrados e eucariotos reforçam este conceito (GINN, 1996; LEE et al., 1996; LIU; OHSHIMA; KIKUCHI, 2001; LOGGINI et al., 2001; MOORE et al., 1995). A P-gp é uma glicoproteína de 170-Kda, transmembrânica, com 
dois domínios ATPase, sendo que o domínio interno transporta compostos hidrofílicos, incluindo muitos agentes quimioterápicos, para o exterior da célula, de forma dependente de energia (LIU; OHSHIMA; KIKUCHI, 2001; NIEHANS et al., 1992), conforme figura 2.1.

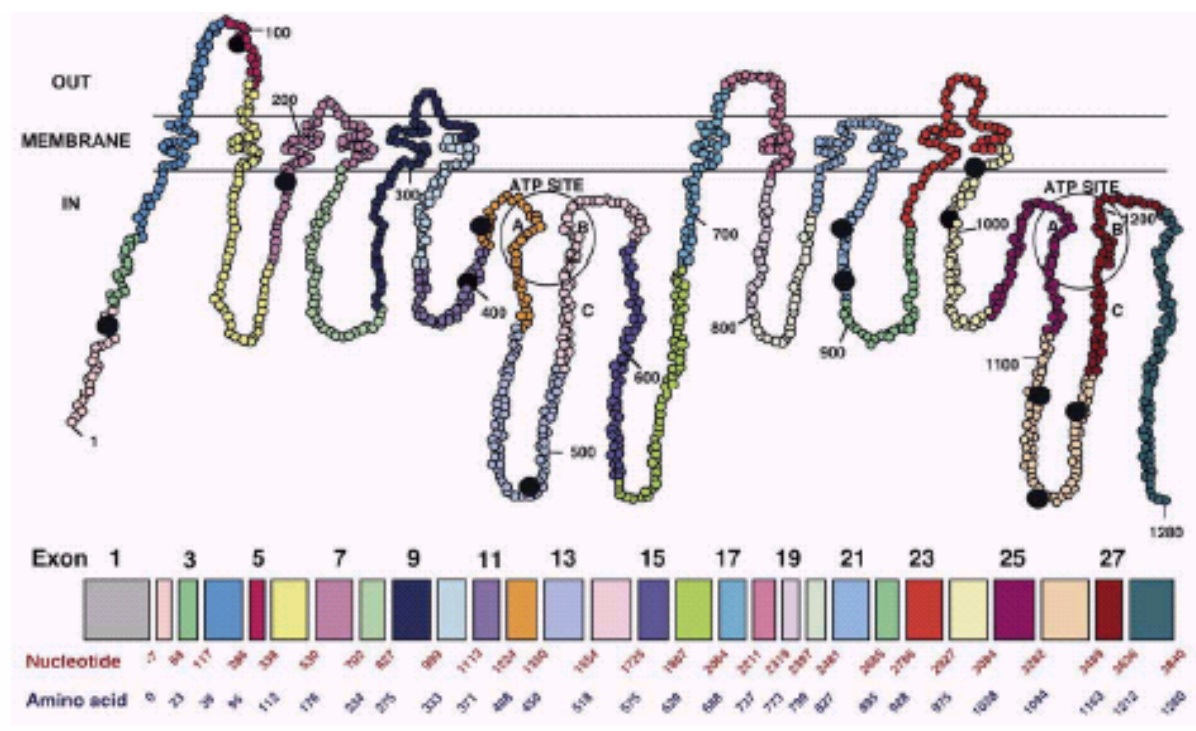

Figura 2.1 - Estrutura da Glicoproteína - P

A maioria dos agentes quimioterápicos é degradada na bicamada fosfolipídica da membrana citoplasmática, difundindo-se em um gradiente de concentração. A P-gp atua contrariamente, expulsando esses agentes para o meio extracelular (AMBUDKAR et al., 2003).

Existem basicamente dois mecanismos de captação de drogas pela membrana citoplasmática. No caso de drogas hidrofílicas como a cisplatina, análogos de nucleosídeos e antifolatos, estas não conseguem cruzar a membrana citoplasmática isoladamente. Há necessidade de transportadores ou a presença de canais hidrofílicos na membrana, para que estes agentes alcancem o meio intracelular (AMBUDKAR et al., 2003). Nestes casos, o fenômeno de resistência, pode ser originado a partir de mutações geradas nestes 
transportadores, resultando no impedimento da entrada destes compostos na célula (AMBUDKAR et al., 2003).

Em relação aos agentes hidrofóbicos, como os alcalóides da vinca, antraciclinas, actinomycina $\mathrm{D}$, etoposídeo e paclitaxel, estes atravessam a membrana citoplasmática por difusão, sem a necessidade de transportadores específicos. Assim, a única forma de manter estas drogas fora da célula é pela ativação dos sistemas de transporte dependentes de energia, como a família da proteínas transportadoras ABC. Seu principal representante, a Pgp, leva à extrusão dessas drogas, resultando no fenótipo MDR (AMBUDKAR et al., 2003).

A P-gp pertence à família de proteínas denominada " ATP- binding cassete $A B C$ " ou simplesmente, família das proteínas transportadoras ABC (AMBUDKAR et al., 2003 ; LAGE, 2003). A P-gp foi a primeira proteína descrita como uma transportadora ABC (AMBUDKAR et al., 2003).

As proteínas transportadoras $\mathrm{ABC}$ são caracterizadas pela presença de uma seqüência de aproximadamente 215 aminoácidos, altamente conservada durante a evolução, designada domínio ABC - ATPase. Este domínio contém 2 peptídios curtos, "walker A ", rico em glicina e " walker B " hidrofóbico, ambos envolvidos na ligação ao ATP. A terceira seqüência é denominada $A B C$, exclusivamente presente nos domínios $A B C$ (LAGE, 2003).

As proteínas $A B C$ estão associadas a pelo menos seis domínios transmembrânicos, $\alpha$ - hélices, hidrofóbicos. Acredita-se que esses domínios determinem a especificidade em relação aos substratos transportados pelas proteínas ABC (LAGE, 2003). Essas proteínas obtêm energia a partir da hidrólise de ATP, necessária para diversos processos celulares como transporte (LAGE, 2003).

Identificaram-se 48 transportadores ABC no genoma humano, divididos em 7 classes diferentes $(A-G)$, de acordo com algumas particularidades. Integrantes de quatro dessas 
classes (A, B, C e G) conferem resistência a drogas "in vitro". Apesar de todos apresentarem uma estrutura $A B C$ semelhante, diferem quanto ao número e localização dos domínios transmembrânicos (AMBUDKAR et al., 2003).

A P-gp em tecidos normais de seres humanos, é expressa em células do córtex da adrenal, na superfície canalicular de hepatócitos, superfície apical das células dos túbulos contornados proximais dos rins, superfície mucosa do intestino delgado e grosso, glândulas sebáceas da pele, endométrio do útero gravídico, trofoblastos da placenta, dutos pancreáticos e células epiteliais de capilares de tecidos como testículos e cérebro (GINN, 1996; LOGGINI et al., 2001).

Nestes locais, a P-gp atua na retirada de compostos xenobióticos tóxicos e no transporte de hormônios esteroidais (NIEHANS et al., 1992). Esta expressão em órgãos secretolíticos revela sua participação fisiológica na eliminação de produtos tóxicos intrínsecos e extrínsecos. Tumores originados dos tecidos citados acima, geralmente expressam a P-gp intrinsecamente, indicando que sua expressão pode ser mantida posteriormente, em uma transformação neoplásica (LOGGINI et al., 2001).

A importância clínica da resistência a múltiplas drogas mediada pelo gene MDR-1 no câncer humano, foi bem investigada nas últimas décadas. Muitos trabalhos científicos recentes relatam métodos de detecção do MDR-1 e da P-gp, o valor prognóstico da expressão da P-gp e as estratégias para se estudar este mecanismo de resistência (LEE et al., 1996).

A P-gp pode ser detectada em tecidos humanos através de técnicas de hibridização, "Imunoblotting", imuno-histoquímica e "Western Blotting" (GINN, 1996; LEE et al., 1996; LIU; OHSHIMA; KIKUCHI, 2001; LOGGINI et al., 2001; MOORE et al., 1995; NIEHANS et al., 1992). Em relação ao gene MDR-1, a reação em cadeia pela polimerase (PCR) constituí o método mais sensível para a detecção de sua expressão (STEINGOLD et al., 1998). 
Os padrões de expressão da P-gp em tumores humanos distribuem-se em quatro categorias (GINN, 1996; LIU; OHSHIMA; KIKUCHI, 2001). A primeira é representada por aqueles tumores com uma expressão intrínseca da P-gp, derivados de células que expressam esta proteína em estado não-neoplásico e são também tradicionalmente refratários ao tratamento com drogas afetadas pelo fenômeno MDR. Os tumores que apresentam expressão intrínseca da P-gp originam-se de órgãos onde existe a expressão fisiológica da P-gp, como as glândulas adrenais e os rins (BERGMAN et al., 1996). A segunda categoria envolve tumores que apresentam uma expressão ocasional da P-gp, como os vários tipos de leucemia, linfoma não-Hodgkin e alguns casos de neoplasias mamárias. Estes tumores são considerados inicialmente sensíveis à quimioterapia. A terceira relaciona-se a neoplasias que desenvolvem uma rara expressão da P-gp e apresentam uma sensibilidade variável à quimioterapia. Incluem-se neste grupo a maioria dos neoplasmas mamários, melanomas, tumores da vesícula urinária, tireóide, timo, ovário e próstata. A quarta categoria abriga tumores que expressam a P-gp após o tratamento, sendo eles o linfoma não-Hodgkin de grau intermediário de malignidade, mieloma múltiplo, leucemias mielóides agudas, sarcomas que se desenvolvem na infância, tumores ovarianos e neuroblastomas. A expressão da Pgp em certos cânceres deste grupo é associada a um mau prognóstico, progressão da doença e previsível resistência a múltiplas drogas (GINN, 1996; LIU; OHSHIMA; KIKUCHI, 2001). Muitos estudos clínicos demonstraram a expressão da P-gp em pacientes portadores de mieloma e seus níveis aumentam quando estes tornam-se resistentes à vincristina e à doxorrubicina (DALTON et al., 1995).

A expressão do MDR-1/P-gp em linfomas não tratados é geralmente baixa e uma alta expressividade desse mecanismo pode ser induzida após o início da 
quimioterapia. Esta expressão foi observada em amostras teciduais de pacientes não submetidos ao tratamento para linfoma e também em pacientes tratados. No entanto, poucos pesquisadores testaram de forma consecutiva amostras teciduais do mesmo paciente, antes e após a quimioterapia (LIU; OHSHIMA; KIKUCHI, 2001).

Os agentes citotóxicos que podem levar à expressão adquirida da P-gp são os alcalóides da vinca (vincristina e vimblastina), antraciclinas (doxorrubicina, daunorrubicina e mitoxantrone), epipodofilotoxinas (etoposídeo), antibióticos (actinomicina D), taxanos (paclitaxel) e corticosteróides, dentre outros (AMBUDKAR et al., 2003; LAGE, 2003), agentes estes, com diferentes estruturas e funções não relacionadas.

Além dos diversos quimioterápicos, existem outras drogas, consideradas substratos da P-gp. São elas a ivermectina, ondasentrona, loperamida, itraconazol, cetoconazol, ciclosporina, rifampicina, fenobarbital, digoxina, doxiciclina, omeprazole e anti-histamínicos (BERGMAN, 2003). Esta informação é importante, uma vez que a utilização concomitante destas drogas com quimioterápicos pode alterar a farmacocinética e toxicidade dos agentes empregados no protocolo quimioterápico, além da possibilidade de indução da resistência a múltiplas drogas (BERGMAN, 2003). Além disso, observou-se que por meio da P-gp, as células cancerígenas tornam-se simultaneamente resistentes a diferentes drogas.

Um estudo realizado em osteossarcoma canino verificou que a expressão da P-gp induzida pela doxorrubicina, foi capaz de conferir resistência cruzada à vincristina, utilizada posteriormente, reduzindo sua citotoxicidade. Sabe-se que vincristina e doxorrubicina pertencem a grupos farmacológicos diferentes, são estruturalmente diversas, porém ambas são substratos para a P-gp (MEALEY et al., 1998). 
Estudos clínicos abrangendo vários tumores malignos constataram o desenvolvimento progressivo da expressão P-gp, durante o tratamento quimioterápico. Nestas condições, a exposição a agentes citotóxicos leva à seleção de clones resistentes. A recidiva da doença maligna condiz com o pico, ou seja, estágio máximo de multiplicação, desses clones malignos (MEALEY et al., 1998).

A investigação dos produtos do gene MDR-1 em tecido normal ou neoplásico de cães é limitada. Células caninas resistentes a drogas são desenvolvidas e estudadas, utilizando-se sondas de produtos de MDR-1 humano. Esses estudos sugerem que produtos do gene MDR sejam semelhantes entre seres humanos e cães (LEE et al.,1996).

A existência de homologia entre o MDR-1 humano e o canino foi relatada pela primeira vez por Steingold et al. (1998). Este estudo revelou 93\% e $74 \%$ de homologia em relação ao MDR-1 e MDR-2 caninos e humanos respectivamente. Detectou-se também, o MDR-1 em linhagens celulares de tecido renal canino e em linfonodos de cães com linfoma multicêntrico (STEINGOLD et al., 1998).

Quantificou-se a presença da P-gp em amostras de linfonodos de cães com linfoma, utilizando a técnica "Western Immunoblotting", confirmando assim, uma expressão similar da P-gp entre cães e seres humanos (LEE et al., 1996; MOORE et al., 1995).

A distribuição tecidual e a localização celular da P-gp em tecidos normais de cães são muito similares a seres humanos, como por exemplo, no fígado, cérebro, córtex da adrenal, rins e cólon (GINN, 1996), porém a expressão no fígado e cérebro é mais elevada do que a observada em seres humanos (CONRAD et al., 2001). Demonstrou-se ainda, que a expressão desta glicoproteína em neoplasmas caninos pode ser comparada a sua expressão em tumores de adrenal, fígado e cólon, no 
homem e que também pode ocorrer em linfomas, carcinomas de glândula mamária e tireóide e melanomas a exemplo do que ocorre em seres humanos (GINN, 1996).

No Brasil, Lucas (2000) (tese de doutorado), investigou a possível presença do gene MDR-1 e da P-gp em um cão com linfoma multicêntrico, por meio da técnica do RT-PCR. As reações RT-PCR e“ Western Blotting” foram realizadas na recidiva do processo neoplásico e houve a expressão do gene MDR-1 e da P-gp.

O linfoma canino é normalmente tratado com alcalóides da vinca e antraciclinas, sendo freqüente o sucesso inicial, seguido por um quadro de resistência a estes agentes (GINN, 1996; MOORE et al., 1995). Especula-se que um dos mecanismos de resistência envolvido no linfoma canino seja mediado pela expressão da P-gp (GINN, 1996; LEE et al., 1996; MOORE et al., 1995).

O uso de corticosteróides previamente à quimioterapia em casos de linfoma canino multicêntrico, constitui um fator prognóstico negativo. Cogita-se que isto possa estar relacionado à indução da expressão da P-gp pela prednisona. influenciando na quimioterapia instituída posteriormente (BERGMAN et al., 1996).

Uma observação interessante sobre o mecanismo MDR/P-gp é que uma das principais funções da P-gp é conferir proteção aos neurônios nos mamíferos, ao se localizar na barreira hematoencefélica, permitindo que drogas, como por exemplo, a ivermectina sejam utilizada com certa segurança. Infelizmente, isto parece não ocorrer em determinadas raças de cães. É notável que cães da raça Collie apresentam uma sensibilidade aumentada aos efeitos da ivermectina e uma possível explicação para este fato seria uma alteração na função da P-gp nesta raça (NEFF et al., 2004; ROULET et al., 2003).

Recentemente, um estudo relatou que um cão da raça Collie, sensível à ivermectina, apresentou uma mutação por deleção no gene MDR-1. Notou-se que o 
RNA mensageiro do MDR-1 embora transcrito, não levava à tradução da proteína funcionante, ou seja, não se detectava a P-gp. Isto explicaria a maior sensibilidade à ivermectina apresentada por cães da raça Collie, uma vez que a P-gp produzida é funcionalmente deficiente, devido à deleção no gene MDR-1 (ROULET et al., 2003).

De forma similar, outro estudo demonstrou que outro cão da raça Collie, com diagnóstico de linfoma multicêntrico, também apresentou uma mutação em um alelo do gene MDR-1. O tratamento quimioterápico foi instituído e observou-se que após a aplicação da vincristina, vimblastina ou doxorrubicina em doses convencionais, o anima apresentava sinais de toxicidade gastrointestinal e mielossupressão bem mais acentuados do que o esperado em cães de outras raças (MEALEY et al., 2003).

As drogas utilizadas no tratamento constituem substratos da P-gp e como cães desta raça apresentam deleção no gene MDR-1, pode-se esperar que haja maior susceptibilidade aos efeitos tóxicos provocados pelas mesmas e neste caso, em cães com deleção no MDR-1, faz-se necessário um acompanhamento rigoroso da quimioterapia e talvez, a redução das doses de fármacos que são substratos da P-gp. É interessante observar que em cães com disfunção na P-gp, pode haver uma taxa de remissão maior do que a esperada, pois a P-gp medeia o fênomeno da resistência a múltiplas drogas, que pode estar diminuído em cães com MDR-1 mutado (heterozigotos) ou até ausente se o animal for homozigoto (MEALEY et al., 2003; NEFF et al., 2004). 


\subsection{PROTEÍNA ASSOCIADA À RESISTÊNCIA A MÚLTIPLAS DROGAS (MRP)}

Em 1992, Cole et al. relataram a existência de um segundo tipo de proteína que também funcionaria como uma bomba de efluxo de drogas, presente em células cancerígenas pulmonares resistentes à doxorrubicina.

Esta nova proteína, designada proteína associada à resistência a múltiplas drogas (MRP), pode explicar parcialmente o fênomeno da resistência a múltiplas drogas em tumores cujo mecanismo envolvido não seja mediado pela P-gp (ZHAN et al., 1997). Numerosas células resistentes a múltiplas drogas, que não expressaram a P-gp, apresentaram uma superexpressão de MRP e um padrão de resistência cruzada similar ao mediado pela P-gp (BERGER et al., 1997).

Muitas células tumorais co-expressam P-gp e MRP (BERGMAN, 2003). A MRP constitui o segundo mecanismo mais freqüente de resistência a múltiplas drogas (BERGMAN, 2003).

A MRP é uma glicoproteína de $190 \mathrm{Kda}$, pertencente à superfamília de proteínas transportadoras ABC (BERGER et al., 1997), conforme figura 2.2, codificada por um gene RNA mensageiro (MRP RNAm), que apresenta homologia com o gene MDR-1 e encontra-se no cromossomo 16 (ZHAN et al., 1997). Em seres humanos, o gene MRP expressa-se em diferentes tecidos como o hematopoiético, músculo esquelético, coração, rins, pulmões, cérebro, fígado e intestinos (LOE; DEELEY; COLE, 1996). 


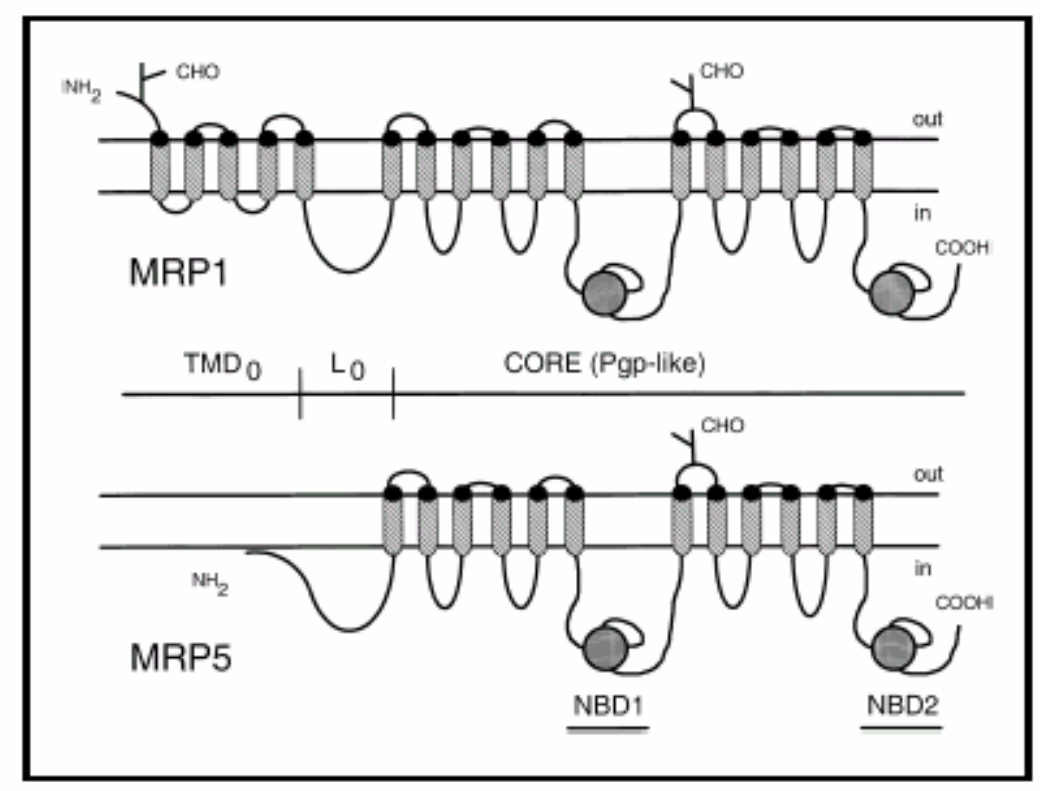

Figura 2.2 - Estrutura da Proteína MRP

Pesquisadores divergem quanto à distribuição intracelular da MRP. Estudos da década passada sugerem uma localização predominante no Retículo Endoplasmático Liso, enquanto outros, uma distribuição na membrana plasmática ou nas vesículas do Complexo de Golgi (LOE; DEELEY; COLE, 1996).

Bergman (2003) afirma que a MRP localiza-se fisiologicamente no citoplasma de células normais, enquanto que nas células neoplásicas, é encontrada na membrana citoplasmática, indicando sua possível função excretora nas mesmas.

Embora o mecanismo de ação da MRP não seja completamente conhecido, esta proteína também atua no aumento do efluxo de drogas, de forma dependente de energia, resultando na redução do acúmulo intracelular de drogas (LOE; DEELEY; COLE, 1996). Participa no transporte de conjugados de glutationa (GSH) e glucuronidios de bilirrubina, drogas neutras conjugadas a sulfato e drogas aniônicas como a metotrexato, no interior da célula e na excreção dos mesmos para o meio extracelular (BORST et al., 2000). Desta forma, a MRP tem importante papel na 
detoxificação e esta também ocorre para os agentes quimioterápicos, facilitando o mecanismo de resistência (BERGMAN, 2003).

Existem várias proteínas homólogas à MRP, sendo a MRP-1 a principal (LAGE, 2003). A MRP-1 foi a segunda proteína descrita como uma transportadora ABC (ABC $C 1)$, isolada a partir de células de câncer de pulmão que não expressavam o gene MDR-1 (LAGE, 2003). Comparada à P-gp, a MRP-1 possuí um domínio transmembrânico adicional (LAGE, 2003) e é ubíqua à maioria dos tecidos, enquanto que a P-gp é expressa principalmente em tecidos que funcionam como barreiras (AMBUDKAR et al., 2003).

Apesar de sua descoberta em 1992, pouco se conhece a respeito de sua importância clínica, ainda não se verificou uma forte associação entre MRP-1 e resistência clínica, mas como a MRP-1 está presente em praticamente todos os tecidos humanos, também é encontrada na maioria dos tumores e devido a sua função, pode estar envolvida na resistência à quimioterapia destes tumores (BORST et al., 2000).

Estudos constataram que a MRP-1 pode conferir resistência a diversos quimioterápicos, incluindo as antraciclinas, alcalóides da vinca, epipodofilotoxinas e metotrexato (LAGE, 2003; ZHAN et al., 1997). O metotrexato, por ser um ânion orgânico, pode formar um complexo com moléculas de glutationa e ser lançado para fora da célula por meio da MRP-1 (BORST et al., 2000).

A MRP-2 parece ser um transportador do glucuronídeo de bilirrubina até a membrana canalicular do hepatócito. A MRP-2 foi encontrada em células neoplásicas resistentes à cisplatina, diferentemente das outras proteínas MRP que não medeiam o transporte desta droga assim como a MRP-1. Além disso, pode conferir resistência às antraciclinas, alcalóides da vinca, epipodofilotoxinas e 
metotrexato (BORST et al., 2000; LAGE, 2003). A MRP-2 pode ser encontrada em 95\% dos carcinomas renais e também nos carcinomas de pulmão, gástrico, colorretal e hepatocelular (BORST et al., 2000).

A MRP-3 tem como substratos os alcalóides da vinca, epipodofilotoxinas e metotrexato, porém contrariamente às MRPs 1 e 2, tem preferência por conjugados de glucuronato como substratos, do que os de glutationa (BORST et al., 2000). Está associada à resistência à doxorrubicina em células de câncer de pulmão (BORST et al., 2000).

A MRP-4 está envolvida na resistência aos antivirais utilizados no tratamento da imunodeficiência humana como o 9-(2-fosfonilmetoxietil)adenina (PMEA) ou azidotimidina monofosfato (AZTMP) e antineoplásicos como o metotrexato. Não se sabe ao certo se a MRP-4 está realmente envolvida no fenótipo MDR (BORST, et al., 2000).

A MRP-5 parece conferir resistência a drogas antivirais como a PMEA e antineoplásicos como as tiopurinas (BORST et al., 2000; LAGE, 2003). A MRP-6 parece não estar associada ao fenótipo MDR (BORST et al., 2000; LAGE, 2003).

A MRP parece estar envolvida na resistência a drogas em casos de neoplasias como leucemias, linfomas, fibrossarcomas, tumores de pulmão, mama, útero, próstata e em carcinoma de bexiga, na espécie humana (BERGER et al., 1997; LAGE, 2003; LOE; DEELEY; COLE, 1996).

Em Medicina Veterinária, pouco se conhece a respeito da MRP. A MRP-1 e MRP-2 foram detectadas em tecidos caninos e alguns pesquisadores já realizaram seu seqüenciamento (CONRAD et al., 2001). A MRP-2 canina possui $83,4 \%$ de homologia em relação à humana (CONRAD et al., 2001). 
Em relação à distribuição tecidual em cães, a MRP-1 foi encontrada principalmente no cérebro, rins, fígado e testículos e com menor expressividade nos pulmões e intestino (CONRAD et al., 2001).

A MRP-2 apresenta expressão elevada nos rins, seguida pelo fígado, duodeno, jejuno. Esta proteína não foi detectada no cólon, pulmões, cérebro e testículos (CONRAD et al., 2001).

Recentemente, detectou-se a MRP, P-gp ou a coexpressão de ambas, em células de mastocitoma canino por meio de imuno-histoquímica (MIYOSHI et al., 2002).

Conforme descrito, as proteínas P-gp e MRP são proteínas transportadoras ABC e desempenham um importante papel fisiológico no transporte de diferentes moléculas por meio das membranas biológicas. Desde células bacterianas, fúngicas, protozoárias até células neoplásicas humanas, esta superfamília de proteínas transportadoras é de fundamental importância para a resistência a drogas (LAGE, 2003).

$A$ atividade dos transportadores $A B C$ representam uma estratégia básica de defesa das células contra o efeito citotóxico de agentes xenobióticos. A caracterização detalhada dos mecanismos causadores de MDR, tanto em células procariotas quanto em eucariotas de microorganismos ou de células neoplásicas humanas é de extrema importância para o desenvolvimento de estratégias terapêuticas para prevenir ou transpor a resistência ao tratamento (LAGE, 2003). 


\subsection{PROTEÍNA RELACIONADA À RESISTÊNCIA DE PULMÃO (LRP)}

A crescente evidência de que outros mecanismos estejam envolvidos no fenômeno de resistência fez com que outras proteínas fossem pesquisadas (KANZAKI et al., 2001). Em 1986, foi identificada uma proteína denominada proteína relacionada à resistência de pulmão ("Lung Resistance Related Protein" - LRP), detectada primeiramente em células tumorais de câncer de pulmão resistentes a múltiplas drogas, por mecanismo não mediado pela P-gp (RAAIJMAKERS et al., 1998) e notaram ser idêntica à maior proteína do grupo "vault" (OHNO et al., 2001).

A proteína descoberta em 1986, foi então denominada "vault" devido a semelhança de sua morfologia aos arcos abobadados de igrejas, conforme observado pela figura 2.3 (VAN ZON et al., 2003).

"Vaults" são organelas citoplasmáticas localizadas na membrana nuclear e no poro nuclear (OHNO et al., 2001; RAAIJMAKERS et al., 1998). Acredita-se que as "vaults" estejam envolvidas nos transportes vesicular e nucleocitoplasmático de drogas (KANZAKI et al., 2001; OHNO et al., 2001).

As "vaults" formam complexos de ribonucleoproteínas de 13 Mda, cujas dimensões atingem 35X65 nm. Desta forma, as "vaults" são as maiores ribonucleoproteínas descritas até o momento. Estruturas com morfologia e dimensões semelhantes foram notadas em células de mamíferos, aves, anfíbios, peixes, moluscos e protozoários. Sabe-se que as "vaults" são altamente conservadas entre os eucariotos, sugerindo assim, uma atividade celular fundamental (CHENG et al., 2000). 

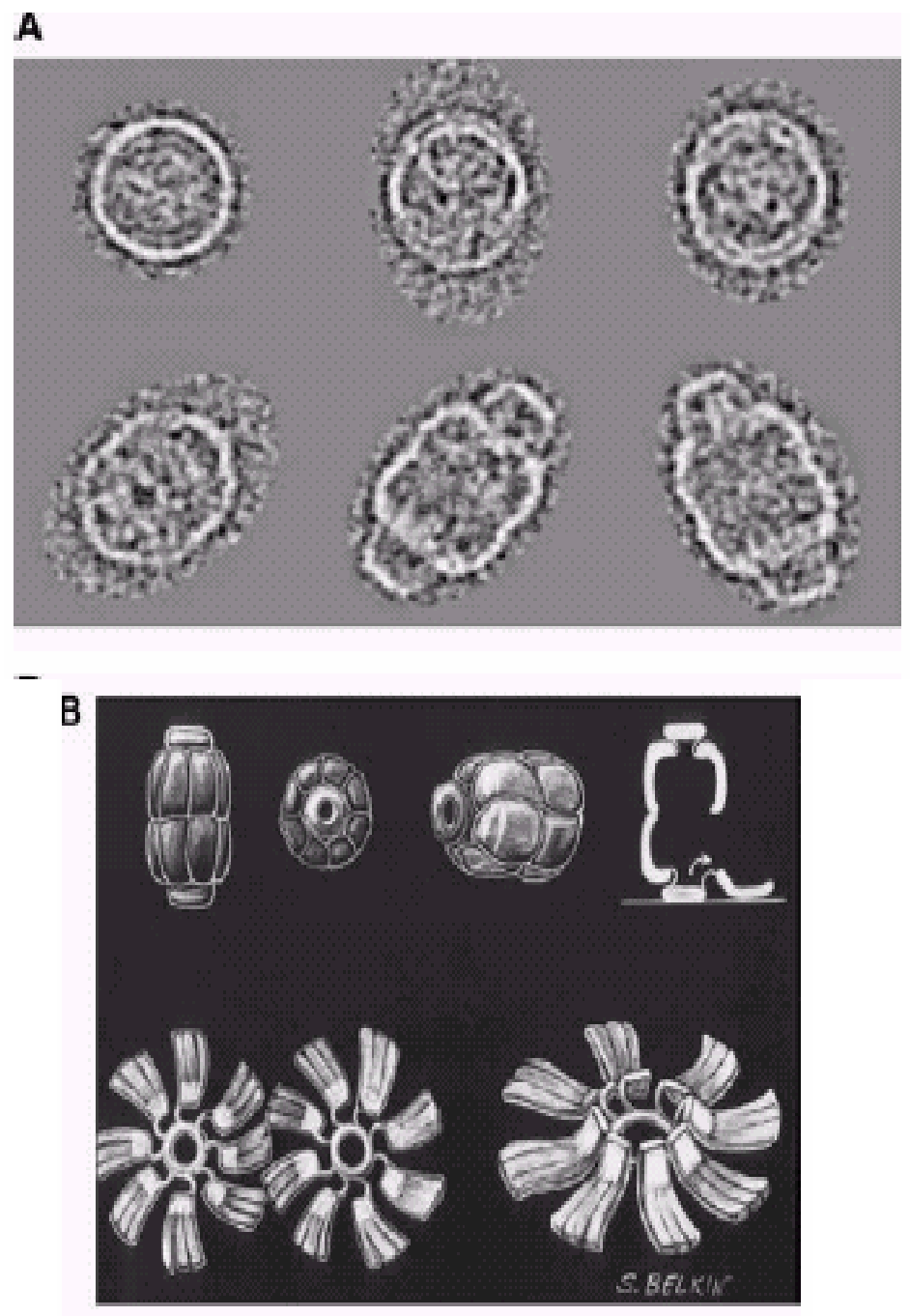

Figura 2.3 - Complexo "vault" em microscopia eletrônica

(A); em desenho esquemático (B)

O complexo "vault" é constituído por 4 componentes distintos, sendo 3 proteínas de alto peso molecular e pequenas moléculas de RNA não traduzidos (OHNO et al., 2001; VAN ZON et al., 2003).

Dentre as 3 proteínas de alto peso molecular, a proteína de $100 \mathrm{Kda}$, denominada "Major Vault Protein" (MVP) constituí mais de 70\% da massa molecular do complexo "vault". A MVP possuí regiões distintas como o domínio $\alpha$-hélice envolvido na interação entre as moléculas MVP e essencial para a formação do complexo "vault" e a região $\mathrm{N}$-terminal, que contém aminoácidos repetidos que 
parece estar envolvida na ligação ao cálcio, necessário para a reunião das MVPs no complexo (VAN ZON et al., 2003).

As outras proteínas do complexo possuem 193 Kda e 240 Kda e são designadas de "Minor Vault Proteins". A subunidade 193 Kda é denominada PARP ou VPARP ou 193. A PARP I ao ser ativada, transfere grupos ADP-ribose de NAD ${ }^{+}$ para si própria e para proteínas de manutenção da cromatina e do metabolismo do DNA. A PARP II também está envolvida no reparo do DNA (VAN ZON et al., 2003).

A proteína $240 \mathrm{Kda}$ parece ser idêntica à telomerase associada à proteína I (TEP I ou p240), mas as "vaults" não têm atividade de telomerase. Não se sabe ao certo qual a função desta subunidade (VAN ZON et al., 2003).

A fração de RNA não traduzido (VRNA) representa $5 \%$ da massa do complexo e sua função dentro deste é incerta. Acredita-se que o VRNA desempenhe um papel mais funcional do que estrutural. O VRNA é espécie-específico, variando de 86 a 141 bases (VAN ZON et al., 2003).

Cogita-se que as proteínas "vault" medeiem o transporte bidirecional de uma variedade de substratos entre o núcleo e o citoplasma celular (RAAIJMAKERS et al., 1998; VAN ZON et al., 2003). Relatou-se a presença de drogas em vesículas de exocitose, no interior de células resistentes a múltiplas drogas, que apresentaram uma alta expressividade da LRP (RAAIJMAKERS et al., 1998).

Um estudo realizado em células de carcinoma de faringe, que apresentaram uma alta expressão de LRP, demonstrou o possível envolvimento desta proteína no transporte nucleocitoplasmático de drogas, resultando no fenótipo MDR. As células de carcinoma de faringe sensíveis e resistentes foram submetidas a determinadas concentrações de benzopireno ou de doxorrubicina e verificou-se a distribuição intracelular destas drogas por microscopia de fluorescência. Notou-se que as células 
sensíveis ao receberem o tratamento com o benzopireno ou doxorrubicina, apresentaram maior acúmulo no núcleo da célula, local de ação destas drogas, do que no citoplasma, conferindo-se assim sensibilidade a estes agentes. Por outro lado, as células resistentes, apresentaram maior acúmulo de drogas no citoplasma do que no núcleo, distanciando-as do seu sítio de ação. Este experimento assim como outros, apontam para a importância desta proteína como mecanismo MDR (CHENG et al., 2000).

A proteína LRP pode ser encontrada fisiologicamente no cólon, pulmões, túbulos contornados proximais renais, córtex da adrenal (FILIPITS et al., 2000).

A LRP apresenta uma alta expressividade em tecidos expostos a longo prazo a agentes xenobióticos como epitélio brônquico, córtex da adrenal e macrófagos (VAN ZON et al., 2003).

A LRP, encontrada em tecidos normais e neoplásicos de seres humanos, pode levar a maior ou menor sensibilidade à quimioterapia por diferentes tipos de tumores (RAAIJMAKERS et al., 1998), principalmente no câncer de pulmão (origem de sua denominação), e também nas leucemias, linfomas e tumores sólidos (MOSSINK et al., 2003; SCHNEIDER et al., 2001).

Embora este mecanismo de resistência ainda não tenha sido extensivamente estudado, foi demonstrado que a LRP está envolvida na resistência à adriamicina e cogita-se que possa estar associada à resistência em casos de neoplasia mamária (SCHNEIDER et al., 2001).

Siva et al. (2001), relataram que linhagens celulares resistentes a múltiplas drogas como carcinoma de pulmão, mieloma e carcinoma de mama, apresentam níveis elevados de MVP (LRP). No entanto, já se demonstrou previamente que a MVP não é suficiente para levar ao fenótipo MDR isoladamente. "Vaults" são 
complexos de múltiplas subunidades e precisam interagir para ocasionar o fenótipo MDR.

Observou-se neste estudo, que a elevada expressão celular da MVP induz à ativação dos respectivos promotores das subunidades VPARP e TEPI. Assim, em conjunto, podem levar ao fenótipo MDR (SIVA et al., 2001).

Estudos recentes em mielomas e em outras neoplasias humanas, relacionaram a expressão da LRP à resistência a agentes alquilantes como o melfalano no caso de mieloma múltiplo (MOSSINK et al., 2003; RAAIJMAKERS et al., 1998). Além disso, a expressão da LRP em células tumorais está associada a resistência à doxorrubicina, vincristina, carboplatina, cisplatina, etoposídeo, paclitaxel e gramicidin D (FILIPITS et al., 2000).

A expressão da LRP também foi associada a uma resposta insatisfatória à quimioterapia e a uma sobrevida curta, em casos de linfoma de células $B$, sugerindo que esta proteína seja um fator de resistência clinicamente relevante em casos de linfoma (FILIPITS et al., 2000).

Um aumento na expressão da proteína LRP pôde ser observado em pacientes com leucemia linfoblástica aguda durante a recidiva, e demonstrou-se uma correlação inversa entre a expressão da LRP e a concentração intracelular de daunorrubicina (SAUERBREY et al., 2002).

No caso de leucemia mielóide aguda em seres humanos, pode-se observar a co-expressão da P-gp, MRPI e LRP simultaneamente. Geralmente, as piores respostas ao tratamento e taxa de sobrevida são observadas em pacientes que coexpressam estas proteínas e o melhor prognóstico em pacientes negativos para as mesmas (MOSSINK et al., 2003). A existência de co-expressão destas proteínas já 
foi relatada previamente por Moran et al. (1997), em células de carcinoma de ovário humano.

Em relação aos tumores sólidos em seres humanos, a expressão da LRP foi notada em câncer de ovário, mama e em neoplasias de epitélio brônquico, ceco, colon, reto, melanoma, osteossarcoma e neuroblastoma (MOSSINK et al., 2003).

Baseando-se no envolvimeto das "vaults" no MDR, a MVP pode constituir um fator prognóstico para resposta à quimioterapia em neoplasias como mieloma múltiplo, leucemia mielóide aguda, carcinoma ovariano e osteossarcoma (SIVA et al., 2001).

Até o momento, poucos estudos contribuíram para a elucidação da paticipação da "vaults" no desenvolvimento de resistência a múltiplas drogas (MOSSINK et al., 2003).

\subsection{RESISTÊNCIA A MÚLTIPLAS DROGAS E LINFOMA CANINO MULTICÊNTRICO}

O Linfoma canino é naturalmente um modelo experimental para o estudo do linfoma não-Hodgkin humano em sua forma mais agressiva, e pode ser útil para o estudo dos mecanismos que levam à resistência a múltiplas drogas (MOORE et al., 1995; STEINGOLD, 1998). Dentre as neoplasias hematopoiéticas na espécie canina, os linfomas são as mais freqüentes, representando 7 a 10\% de todas as neoplasias malignas nessa espécie (DOBSON; GORMAN, 1993; ETTINGER, 2003; FAN, 2003). São processos neoplásicos de elevada complexidade biológica caracterizados pela transformação maligna de células linfóides (DOBSON; GORMAN, 1993; ETTINGER, 2003; MORRINSON, VONDERHAAR, 2002; WITRHOW, MACEWEN, 1996). Afeta 
predominantemente cães de meia idade, embora cães jovens e idosos também possam ser acometidos ( ETTINGER, 2003; MOORE et al., 1995).

Em relação à predisposição sexual, as informações da literatura são divergentes. Jain (1986) e Ettinger (2003), sugerem a não existência de predisposição sexual, enquanto Rallis et al. (1992) e Dobson e Gorman (1993), relatam marcante predisposição com a incidência de machos superando a de fêmeas em uma relação 2:1. Quanto as raças, parece existir certa predisposição genética já que alguns estudos denotam a ocorrência familiar da doença (ETTINGER, 2003; ONIONS, 1984; WITHROW, MACEWEN, 2001).

A etiologia do linfoma canino ainda não é completamente conhecida (FAN, 2003). Owen et al. (1975) relacionaram o desenvolvimento do linfoma a um desequilíbrio na imunorregulação. Estudos genéticos descrevem aberrações cromossômicas em casos de linfoma canino, entretanto, anormalidades bem definidas ainda não foram encontradas (HAHN et al., 1994). Sugere-se ainda, o envolvimento de fatores genéticos, ambientais ou infecciosos neste processo (FAN, 2003; TESKE, 1994; WITHROW, MACEWEN, 2001). O papel das viroses na etiologia do linfoma canino também é controverso, embora até hoje nada tenha sido comprovado (FAN, 2003; TESKE, 1994; WITHROW, MACEWEN, 2001).

A Organização Mundial de Saúde classifica o linfoma canino com base nos aspectos considerados na afecção humana: localização anatômica, estágio clínico e critérios histológicos. Quanto à localização anatômica, os linfomas podem ser classificados em multicêntrico, forma mais comum em cães (ETTINGER, 2003; MADWELL; THEILEN, 1987) caracterizado por linfoadenomegalia periférica e por vezes acometimento de outros órgãos; forma alimentar, na qual os linfonodos mesentéricos e tecido linfático intestinal estão envolvidos; forma mediastinal, cuja 
característica é o envolvimento de linfonodos mediastínicos e/ou timo; forma cutânea, caracterizada pelo comprometimento da pele no decorrer da doença e a leucemia verdadeira, na qual apenas a medula está comprometida (ETTINGER, 2003; MADWELL; THEILEIN, 1987). Os linfomas são também classificados com base no envolvimento dos linfonodos (estágios I a III), fígado e baço (estágio IV) e medula óssea e outros órgãos (V) e subclassificados na dependência da ausência (a) ou presença (b) de sinais sistêmicos (ETTINGER, 2003; ROSENTHAL, 1990; WITHROW; MACEWEN, 2001).

Quanto aos critérios histológicos, atualmente, a classificação mais utilizada é a "Working Formulation", na qual os linfomas são agrupados em relação ao prognóstico e aos tipos celulares e classificados em baixo, intermediário e alto grau de malignidade (NATIONAL CANCER INSTITUTE, 1982). A maioria dos linfomas caninos apresenta arquitetura difusa, elevada taxa mitótica, intermediário a alto grau de malignidade (ETTINGER, 2003; MACEWEN; YOUNG, 1996).

Os achados clínicos associados ao linfoma são variáveis e dependem da extensão e localização do tumor. Sendo a forma multicêntrica a mais comum, o achado mais freqüente é a linfoadenomegalia periférica. Uma ampla gama de sintomas inespecíficos como anorexia, perda de peso, êmese, diarréia, emanciação, anemia, ascite, dispnéia, polidipsia, poliúria e hipertermia podem estar presentes, relacionados à neoplasia em si ou a síndromes paraneoplásicas (ETTINGER, 2003; MACEWEN; YOUNG, 1996; MORRINSON; VADERHAAR, 2002; WITHROW; MACEWEN, 2001).

No caso dos cães sabe-se que, embora os linfomas multicêntricos sejam fatais quando não tratados, com o óbito ocorrendo entre 30 a 60 dias após o diagnóstico (ETTINGER, 2003; MACEWEN; YOUNG, 1996; MORRINSON; 
VADERHAAR, 2002; ROSENTHAL, 1990; WITHROW; MACEWEN, 2001), os animais em geral, respondem bem à quimioterapia, sendo o tratamento baseado em drogas alquilantes (ciclofosfamida), alcalóides da vinca (vincristina) e glicocorticóides (prednisona), com algumas variações que incluem a utilização da doxorrubicina, metotrexato e L-asparaginase (ETTINGER, 2003; MACEWEN; YOUNG, 1996; MORRINSON, VADERHAAR, 2002; ROSENTHAL, 1990; WITHROW; MACEWEN, 2001).

A maioria dos pacientes apresenta remissão completa (diminuição de $80 \%$ do volume dos linfonodos) após a fase inicial da quimioterapia, entretanto, mesmo com uma boa resposta ao tratamento, as recidivas são freqüentes durante o período de manutenção da remissão (ETTINGER, 2003; MACEWEN; YOUNG, 1996; ROSENTHAL, 1990; WITHROW; MACEWEN, 2001). Neste momento, a quimioterapia com drogas diferentes daquelas utilizadas inicialmente não produz mais resposta e este fato pode estar relacionado ao fênomeno MDR, a exemplo do que ocorre em seres humanos com linfoma não-Hodgkin (MOORE et al., 1995).

A resistência a drogas é bastante comum em cães com linfoma multicêntrico submetidos à quimioterapia. A maioria dos protocolos terapêuticos induzem a uma rápida remissão do tumor em $80 \%$ casos, entretanto, a recidiva é esperada. Neste momento, poucos agentes são capazes de levar a uma segunda remissão e as chances de uma resposta satisfatória caem para aproximadamente $40 \%$ e muitas vezes, não há resposta (MACEWEN; YOUNG, 1996). Esta inabilidade em tratar pacientes após a recidiva do linfoma está provavelmente, relacionada aos diversos mecanismos de resistência a múltiplas drogas, como o MDR-1, MRP e LRP e seus produtos (BERGMAN; OGILVIE; POWERS, 1996 ). 
Como nos casos de neoplasias humanas, o insucesso do tratamento do linfoma canino é atribuído, além de fatores como idade, doenças concomitantes e estágio do tumor, ao desenvolvimento de resistência a múltiplas drogas, o que torna esse último fator fundamental, já que o diagnóstico dos mecanismos que causam a resistência permite que o tratamento seja estrategicamente repensado de modo que alguns desses mecanismos possam ser transpostos por outros meios, como a mudança das drogas quimioterápicas afetadas pelos mecanismos de MDR descritos. 


\section{MATERIAL E MÉTODOS}

\subsection{CRITÉRIOS DE INCLUSÃO E DE EXCLUSÃO}

Foram atendidos inicialmente, no Hospital Veterinário da Faculdade de Medicina Veterinária e Zootecnia da Universidade de São Paulo (FMVZ-USP), 33 animais da espécie canina, de raças e idades variadas e com diagnóstico de linfoma multicêntrico. Dentre esses cães, 15 foram incluídos no presente estudo, após consentimento dado pelo proprietário.

Foram excluídos aqueles animais que haviam recebido quaisquer tratamentos prévios, a exemplo da corticoideterapia, e com a presença de outras neoplasias.

Os proprietários foram orientados sobre todos os procedimentos adotados previamente à quimioterapia e no decurso da mesma; assinaram o termo de consentimento e tiveram a opção de aceitar participar do estudo ou serem atendidos normalmente na rotina do Serviço de Clínica Médica do Hospital Veterinário da FMVZ-USP.

\subsection{AVALIAÇÃO DOS PACIENTES}

Foram realizados anamnese, exame físico e exames complementares de acordo com o protocolo do Departamento de Clínica Médica da FMVZ-USP. Durante o exame físico foram mensurados os diâmetros dos linfonodos e realizada a punção aspirativa para exame citológico. Após o exame físico, os 
animais foram submetidos a exames radiográfico do tórax e ultrassonográfico do abdomen.

Foram colhidos 6,0 mL de sangue por punção venosa jugular ou cefálica, sendo 2,0 $\mathrm{mL}$ de sangue acondicionados em frasco contendo EDTA a $10 \%$ para realização do hemograma e contagem de plaquetas. Os esfregaços sangüíneos para análise da morfologia celular e contagem diferencial de leucócitos foram confeccionados com sangue in natura no momento da colheita. O restante do sangue $(4,0 \mathrm{~mL})$, mantido em frasco siliconizado sem anticoagulante, foi centrifugado para a obtenção de soro sangüíneo e aliquotado para a realização das demais provas laboratoriais. Foram colhidos ainda $10,0 \mathrm{~mL}$ de urina, acondicionada em seringa ou em coletor universal para realização de exame de urina tipo I.

\subsection{EXAMES COMPLEMENTARES}

\subsubsection{Hemograma}

A contagem das células sangüíneas e plaquetas foi determinada em contador automático Serono Baker 9020, de uso veterinário. A contagem diferencial dos leucócitos e a avaliação morfológica de hemácias e leucócitos foi realizada em esfregaço sangüíneo corado pelo corante de Rosenfeld (BIRGEL, 1982). Os hemogramas foram realizados como parte da avaliação inicial dos animais, antes da instituição do tratamento e durante o mesmo, antecedendo a aplicação dos quimioterápicos. 


\subsubsection{Análise Bioquímica}

As análises bioquímicas foram feitas em analisador automático (Liasys Roche) utilizando-se, quando necessário, kits comerciais.

Essas análises envolveram a avaliação das funções renal (uréia e creatinina) e hepática (proteínas totais, albumina, alanina-aminotransferase, aspartato-aminotransferase, gamaglutamiltransferase e fosfatase alcalina) e eletrólitos (cálcio e fósforo) por meio dos seguintes métodos:

Alanina aminotransferase (ALT): Biosystems - método cinético ultra-violeta, segundo Bergmeyer, 1974.

Albumina: método colorimétrico do Verde de Bromocresol, conforme DoumasBiggs (DOUMAS et al, 1971).

Aspartato aminotransferase (AST): Biosystems - método cinético ultra-violeta, segundo Bergmeyer, 1974.

> Cálcio: método colorimétrico arsenazo Biosystems, conforme Michaylova e LLLkova, 1971.

$>$ Creatinina: método colorimétrico de picrato alcalino, conforme Lustgarten e Wenk, 1972.

$>$ Fosfatase Alcalina (FA): método cinético colorimétrico SCE, segundo Pentilla et al., 1975.

Fósforo inorgânico: método enzimático colorimétrico Biosystems, conforme Gamst e Try, 1980.

Proteínas séricas totais: método colorimétrico do Biureto, segundo Gornall, 1949. 
Uréia: método enzimático da urease, em ultra violeta, segundo Tiffany et al., 1972.

\subsubsection{Urina Tipo I}

O exame químico foi realizado com tiras reagentes (Combur UX). A densidade urinária foi determinada por refratometria. O sedimento urinário foi obtido pela centrifugação de $10 \mathrm{~mL}$ de urina por 5 minutos a $200 \mathrm{~g}$ obtendo-se o volume de sedimento de $1,0 \mathrm{~mL}$. O exame de urina foi realizado antes do início do tratamento e a cada 30 dias durante o tratamento ou em período menor quando manifestações clínicas como hematúria, polaquiúria ou disúria indicaram a necessidade.

\subsubsection{Exames de Imagem}

Realizaram-se radiografias torácicas nas posições latero-lateral e ventrodorsal, de acordo com os métodos utilizados na rotina do Serviço de Diagnóstico por Imagem do Hospital Veterinário da FMVZ-USP; ultra-sonografia abdominal, utilizando-se transdutores de 5,0 e 7,5 $\mathrm{MHz}$, de acordo com o porte e peso dos animais e ecocardiograma previamente a cada aplicação de doxorrubicina, na recidiva, com intuito de monitorar a possível cardiomiotoxicidade, promovida pela mesma. 


\subsubsection{Punção Aspirativa de Linfonodo}

Foi realizada com agulha $25 \times 0,7 \mathrm{~mm}$, em linfonodos preferencialmente em linfonodos poplíteos, com a finalidade diagnóstica e com agulha $40 \times 16 \mathrm{~mm}$ antes do início do tratamento quimioterápico e na recidiva do processo tumoral, para detecção da possível expressão dos genes MDR-1, MRP e LRP e das proteínas P-gp, MRP e LRP.

\subsubsection{Estadiamento do Linfoma}

Foi realizado com base no sistema de estadiamento clínico para linfomas em animais domésticos da Organização Mundial de Saúde (OMS):

I- Envolvimento limitado a um único linfonodo ou tecido linfóide, em um único órgão, excluindo a medula óssea.

II- Envolvimento de vários linfonodos em uma determinada região.

III- Envolvimento generalizado dos linfonodos.

IV- Envolvimento do fígado e/ou baço, com ou sem aumento generalizado dos linfonodos.

V- Envolvimento da medula óssea e/ou outros órgãos.

Cada estágio é subclassificado em:
a) sem sinais sistêmicos.
b) Com sinais sistêmicos. 


\subsection{TRATAMENTO}

Os animais foram submetidos a um dos dois protocolos quimioterápicos utilizados rotineiramente no Serviço de Clínica Médica do HOVET-FMVZ-USP, de forma aleatória.

\subsubsection{Protocolo COP}

Os cães com linfoma incluídos neste protocolo de tratamento, receberam quimioterapia combinada com ciclofosfamida $\left(250 \mathrm{mg} / \mathrm{m}^{2}\right)$, vincristina $\left(0,75 \mathrm{mg} / \mathrm{m}^{2}\right)$ e prednisona $\left(40 \mathrm{mg} / \mathrm{m}^{2}\right.$ ) por 52 semanas, seguindo o esquema de aplicações exposto no quadro 3.1 .

No esquema de tratamento proposto, realizou-se a terapia de indução, com uma administração de ciclofosfamida, associada a uma aplicação de vincristina, a cada 7 dias, se a contagem de leucócitos permitisse, e prednisona diariamente durante 14 dias iniciais e após isso, em dias alternados, durante 4 semanas consecutivas. Caso o animal apresentasse alguma reação, a ciclofosfamida seria substituída por clorambucil.

$\mathrm{Na}$ fase de manutenção do tratamento, os animais receberam vincristina e ciclofosfamida a cada 3 semanas, e prednisona em dias alternados até 52 semanas. 


\begin{tabular}{|c|c|c|c|c|c|c|c|c|c|c|c|}
\hline \multicolumn{12}{|c|}{ Esquema do protocolo COP } \\
\hline Sem & \multicolumn{3}{|c|}{ DROGAS } & Sem & \multicolumn{3}{|c|}{ DROGAS } & Sem & \multicolumn{3}{|c|}{ DROGAS } \\
\hline & V & $\mathrm{P}$ & C & & V & $\mathrm{P}$ & C & & V & $\mathrm{P}$ & C \\
\hline 1 & * & ** & * & 19 & * & $\star \star *$ & * & 37 & * & $\star \star *$ & * \\
\hline 2 & * & ** & & 20 & & $\star \star *$ & & 38 & & $\star \star$ & \\
\hline 3 & * & ** & & 21 & & ** & & 39 & & ** & \\
\hline 4 & * & $\star *$ & * & 22 & * & $\star \star *$ & * & 40 & * & $\star \star *$ & * \\
\hline 5 & & ** & & 23 & & ** & & 41 & & $\star \star$ & \\
\hline 6 & & $\star \star$ & & 24 & & ** & & 42 & & $\star \star$ & \\
\hline 7 & * & ** & * & 25 & * & $\star \star$ & * & 43 & * & $\star \star *$ & * \\
\hline 8 & & ** & & 26 & & 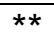 & & 44 & & $\star \star$ & \\
\hline 9 & & ** & & 27 & & 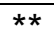 & & 45 & & $\star \star$ & \\
\hline 10 & * & ** & * & 28 & * & ** & * & 46 & * & $\star \star$ & * \\
\hline 11 & & ** & & 29 & & ** & & 47 & & $\star \star$ & \\
\hline 12 & & $\star \star *$ & & 30 & & $\star \star$ & & 48 & & $\star \star$ & \\
\hline 13 & * & $\star *$ & * & 31 & * & $\star \star *$ & * & 49 & * & $\star \star *$ & * \\
\hline 14 & & $\star \star *$ & & 32 & & $\star \star *$ & & 50 & & $\star *$ & \\
\hline 15 & & $\star \star *$ & & 33 & & ** & & 51 & & $\star \star *$ & \\
\hline 16 & * & ** & * & 34 & * & $\star \star$ & * & 52 & * & ** & * \\
\hline 17 & & $\star \star *$ & & 35 & & $\star \star *$ & & & & & \\
\hline 18 & & ** & & 36 & & $\star \star$ & & & & & \\
\hline
\end{tabular}

Legenda: V- vincristina, P- prednisona, C- Ciclofosfamida, Sem- semana, *uma aplicação, ** diariamente durante os 14 dias iniciais e depois em dias alternados até o final do tratamento

Quadro 3.1 - Esquema do protocolo quimioterápico COP, utilizado em 9 cães do estudo, no Serviço de Clínica Médica - HOVET da FMVZ-USP, São Paulo março/03 a setembro/04

\subsubsection{Protocolo VCM}

Os cães com linfoma, incluídos neste protocolo de tratamento, receberam uma aplicação de L-asparaginase por via intramuscular $\left(10.000 \mathrm{UI} / \mathrm{m}^{2}\right)$ em dose única, vincristina $\left(0,75 \mathrm{mg} / \mathrm{m}^{2}\right)$, ciclofosfamida $\left(250 \mathrm{mg} / \mathrm{m}^{2}\right)$ e metotrexato $(0,8$ $\mathrm{mg} / \mathrm{Kg}$ ) segundo o esquema descrito a seguir: 


\begin{tabular}{|c|c|c|c|c|c|c|c|c|c|c|c|}
\hline \multicolumn{12}{|c|}{ Esquema do protocolo VCM } \\
\hline Sem & \multicolumn{3}{|c|}{ DROGAS } & Sem & \multicolumn{3}{|c|}{ DROGAS } & Sem & \multicolumn{3}{|c|}{ DROGAS } \\
\hline & V & C & $M$ & & V & $\mathrm{C}$ & $\mathrm{M}$ & & V & C & $\mathrm{M}$ \\
\hline 1 & * & & & 19 & * & & & 37 & & & \\
\hline 2 & & * & & 20 & & & * & 38 & & & * \\
\hline 3 & * & & & 21 & * & & & 39 & & & \\
\hline 4 & & & * & 22 & & * & & 40 & * & & \\
\hline 5 & * & & & 23 & * & & & 41 & & & \\
\hline 6 & & * & & 24 & & & * & 42 & & * & \\
\hline 7 & * & & & 25 & * & & & 43 & & & \\
\hline 8 & & & * & 26 & & * & & 44 & * & & \\
\hline 9 & * & & & 27 & * & & & 45 & & & \\
\hline 10 & & * & & 28 & & & & 46 & & & * \\
\hline 11 & * & & & 29 & & & * & 47 & & & \\
\hline 12 & & & * & 30 & & & & 48 & * & & \\
\hline 13 & * & & & 31 & * & & & 49 & & & \\
\hline 14 & & * & & 32 & & & & 50 & & & * \\
\hline 15 & * & & & 33 & & * & & 51 & & & \\
\hline 16 & & & * & 34 & & & & 52 & * & & \\
\hline 17 & * & & & 35 & * & & & & & & \\
\hline 18 & & * & & 36 & & & & & & & \\
\hline
\end{tabular}

Legenda: V- vincristina, C- ciclofosfamida, M- metotrexato, Sem- semana, \# 1 aplicação de L-asparaginase no início da indução da remissão, no mesmo dia da primeira dose de vincristina.

Quadro 3.2 - Esquema do protocolo quimioterápico VCM, utilizado em 6 cães do estudo, no Serviço de Clínica Médica, HOVET da FMVZ-USP, São Paulo - março/03 a setembro/04

Nesse tratamento quimioterápico combinado, o animal recebeu uma dose de vincristina e uma aplicação intramuscular de L-asparaginase no mesmo dia. Na semana seguinte recebeu uma dose ciclofosfamida, seguida por outra aplicação de vincristina na terceira semana, e na quarta semana uma aplicação de metotrexato. A partir da semana 27, os ciclos quimioterápicos ocorreram a cada 2 semanas. Caso o animal apresentasse alguma reação, a ciclofosfamida seria substituída por clorambucil.

Essa seqüência de aplicações repetiu-se, à exceção da L-asparaginase que é administrada em dose única, até 2 anos de tratamento ou até a recidiva do tumor. 
Em casos de recidiva, os animais incluídos em qualquer um dos dois protocolos de tratamento passaram a receber doxorrubicina $\left(30 \mathrm{mg} / \mathrm{m}^{2}\right)$ a cada 21 dias ou lomustina $\left(90 \mathrm{mg} / \mathrm{m}^{2}\right)$ a cada 3 ou 4 semanas como protocolos de resgate.

\subsubsection{Avaliação da Resposta ao Tratamento}

A resposta ao tratamento foi avaliada semanalmente pela mensuração dos linfonodos e a resposta foi determinada no dia 22 (final do período de indução) como remissão completa $(\mathrm{RC})$ quando não haviam tumores detectáveis; remissão parcial (RP) se os linfonodos diminuissem $>50 \%$ de seu volume ou ausência de resposta nos casos em que ocorresse $<50 \%$ de redução dos linfonodos. A duração da remissão foi calculada a partir do primeiro dia em que a remissão foi identificada, até a recidiva dos sintomas. O tempo de sobrevida foi calculado do primeiro dia do tratamento até a morte ou eutanásia do animal. 


\subsection{ANÁLISE DA RESISTÊNCIA A MÚLTIPLAS DROGAS POR BIOLOGIA MOLECULAR}

\subsubsection{Conservação e Preparo do Material Analisado}

Colheu-se material de um dos linfonodos periféricos, após tricotomia e assepsia local. O material foi depositado em tubo de colheita à vácuo, estéril, contendo EDTA líquido, refrigerado e imediatamente encaminhado para o Laboratório de Hematologia Molecular, LIM-31, FM-USP.

\subsubsection{Extração de RNA}

Foi adicionado $1 \mathrm{~mL}$ de TRIzol para cada $1 \mathrm{~g}$ de aspirado de linfonodo $\mathrm{e}$ homogeneizou-se bem com uma pipeta. Incubou-se por 5 minutos à temperatura ambiente. Adicionou-se $200 \mu \mathrm{L}$ de clorofórmio e agitou-se vigorosamente por 15 segundos, seguido de repouso por 3 minutos à temperatura ambiente. Centrifugouse a $12.000 \times \mathrm{g}$ por 15 minutos a $4^{\circ} \mathrm{C}$. A fase aquosa foi transferida para um novo tubo previamente esterilizado. Adicionou-se $500 \mu \mathrm{L}$ de isopropanol e incubou-se por 10 minutos à temperatura ambiente. Centrifugou-se a $12.000 \times \mathrm{g}$ por 10 minutos a $4^{\circ} \mathrm{C}$ e o sobrenadante foi descartado. $\mathrm{O}$ precipitado foi lavado com $1 \mathrm{~mL}$ de etanol 75\% em água tratada com dietilpirocarbonato (DEPC) e homogeneizou-se em vortex, suavemente, por 15 segundos. Centrifugou-se a $7.500 \times$ g por 5 minutos a $4^{\circ} \mathrm{C}$, descartando-se o sobrenadante. O precipitado foi colocado para secar ao ar por 15 minutos à temperatura ambiente e dissolvido em $50 \mu \mathrm{L}$ de água tratada com 
DEPC, conforme Chomczynski e Sacchin (1987). A integridade do RNA foi analisada por eletroforese em gel de agarose de alta resolução a 1\% corado com brometo de etídio e visualizado em transiluminador UV.

\subsubsection{Quantificação dos RNAs}

As amostras de RNA total foram determinadas em "GeneQuant ${ }^{\circledR}$ " por espectrofotometria em luz ultravioleta nos comprimentos de onda 260 e $280 \mathrm{~nm}$, obtendo-se concentração em $\mu \mathrm{g} / \mathrm{mL}$, absorbância em $\mathrm{nm}$, pureza em \% e razão de RNA. A razão representa a relação entre a absorbância obtida a 260 nm e 280nm.

\subsubsection{Estudo da Expressão do Gene MDR-1 por RT-PCR}

Os primers utilizados na reação de RT-PCR foram:

MDR1-S 5'- CCC ATC ATT GCA ATA GCA GG- 3'

MDR1-AS 5'-GTT CAA ACT TCT GCT CCT GA- 3'

As misturas de reação de RT-PCR foram montadas utilizando-se kit comercial Ready-to-go RT-PCR Beads (Amersham Pharmacia Biotech), de acordo com as instruções do fabricante. Para a síntese de cDNA (foram utilizados os mesmos primers ou iniciadores descritos para a reação de amplificação), incubou-se a mistura de reação por 30 minutos a $50^{\circ} \mathrm{C}$, seguida por um ciclo de desnaturação a $94^{\circ} \mathrm{C}$, durante 2 minutos. $\mathrm{A}$ amplificação foi realizada nas seguintes condições: desnaturação por 30 segundos a 
$94^{\circ} \mathrm{C}$; anelamento por 30 segundos a $55^{\circ} \mathrm{C}$ e extensão por 1 minuto a $72^{\circ} \mathrm{C}$, totalizando 40 ciclos. Para a extensão final, as amostras foram incubadas a $72^{\circ} \mathrm{C}$ por 8 minutos. Os produtos de amplificação foram analisados por eletroforese em gel de poliacrilamida a $6 \%$ corado com nitrato de prata ou por gel de agarose $2 \%$ corado por brometo de etídio. $\mathrm{O}$ produto de amplificação desta reação é de 147 pares de bases. A temperatura ótima de anelamento para esta reação foi obtida a partir de um gradiente de temperaturas.

\subsubsection{Estudo da Expressão do Gene MRP por RT-PCR}

Os primers utilizados foram:

MRP-S: $\quad$ 5'- CTG AAA CCA TCC ATG ACC TCA ATC C- 3'

MRP-AS: $\quad$ 5'- GCC TCC TCG TTC ACG TCC ACC TGG G - 3'

As misturas de reação de RT-PCR foram montadas utilizando-se kit comercial Ready-to-go RT-PCR Beads (Amersham Pharmacia Biotech), de acordo com as instruções do fabricante. Para a síntese de cDNA (foram utilizados os mesmos primers ou iniciadores descritos para a reação de amplificação), incubou-se a mistura de reação por 30 minutos a $50^{\circ} \mathrm{C}$, seguida por um ciclo de desnaturação a $94^{\circ} \mathrm{C}$, durante 2 minutos. A amplificação foi realizada nas seguintes condições, segundo Zhan et al. (1997): desnaturação por 1 minuto e 15 segundos a $94^{\circ} \mathrm{C}$; anelamento por 1 minuto e 15 segundos a $55^{\circ} \mathrm{C}$ e extensão por 1 minuto e 30 segundos a $72^{\circ} \mathrm{C}$, totalizando 20 ciclos, e desnaturação por 1 minuto e 15 segundos a $94^{\circ} \mathrm{C}$; anelamento por 1 minuto e 15 segundos a $55^{\circ} \mathrm{C}$ e extensão por 2 minutos a $72^{\circ} \mathrm{C}$, totalizando mais 10 ciclos. Para a extensão final, 
as amostras foram incubadas a $72^{\circ} \mathrm{C}$ por 8 minutos. Os produtos de amplificação foram analisados por eletroforese em gel de poliacrilamida a $6 \%$ corado com nitrato de prata. O tamanho do produto desta reação é de 295 pares de bases.

\subsubsection{Estudo da Expressão do Gene LRP por RT-PCR}

Os primers utilizados foram os seguintes:

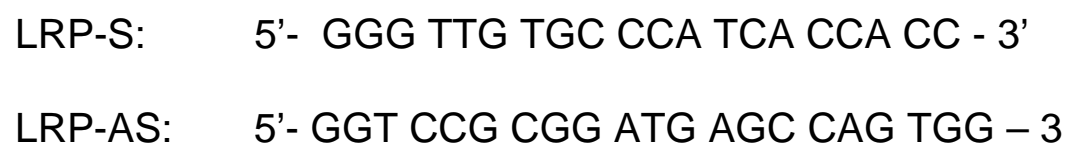

Pela técnica do RT-PCR, para a síntese de cDNA (foram utilizados os mesmos primers ou iniciadores descritos para a reação de amplificação), incubandose a mistura de reação por 30 minutos a $50^{\circ} \mathrm{C}$, seguida por um ciclo de desnaturação a $94^{\circ} \mathrm{C}$, durante 2 minutos. A amplificação foi feita com 38 ciclos de: desnaturação por 40 segundos a $94^{\circ} \mathrm{C}$; anelamento por 40 segundos a $52.2^{\circ} \mathrm{C}$ e extensão por 60 segundos a $72^{\circ} \mathrm{C}$. A extensão final foi realizada durante 8 minutos a $72^{\circ} \mathrm{C}$. Estas condições foram descritas por Sauerbrey et al. (2002) para estudo do gene LRP em seres humanos, exceto a temperatura ideal de anelamento adequada para a espécie canina, obtida a partir de uma reação de RT-PCR com gradiente de temperaturas de anelamento.

Os produtos do RT-PCR foram analisados em gel de poliacrilamida a $6 \%$ corados com nitrato de prata, ou em gel de agarose a $2 \%$, corado com brometo de etídio. O produto de amplificação desta reação é de 280 pares de bases. 


\subsubsection{Estudo da Expressão do Gene $\beta_{2}$-microglobulina Canina por RT-PCR}

A $\beta-2$ microglobulina canina foi utilizada como controle interno de amplificação das reações de RT-PCR. Os primers utilizados nesta reação foram:

DOG $\beta_{2}-\mathrm{S}: \quad$ 5'- TTC AGC AAG GAC TGG TCT TT - 3'

DOG $\beta_{2}$-AS: 5'- CTG CTT ACA TGT CTC GAT CT - 3'

As misturas de reação de RT-PCR foram montadas utilizando-se kit comercial Ready-to-go RT-PCR Beads (Amersham Pharmacia Biotech), de acordo com as instruções do fabricante. Para a síntese de cDNA (foram utilizados os mesmos primers ou iniciadores descritos para a reação de amplificação), incubou-se a mistura de reação por 30 minutos a $50^{\circ} \mathrm{C}$, seguida por um ciclo de desnaturação a $94^{\circ} \mathrm{C}$, durante 2 minutos. A amplificação foi realizada nas seguintes condições: desnaturação por 30 segundos a $94^{\circ} \mathrm{C}$; anelamento por 30 segundos a $62.7^{\circ} \mathrm{C}$ e extensão por 1 minuto a $72^{\circ} \mathrm{C}$, totalizando 40 ciclos. Para a extensão final, as amostras foram incubadas a $72^{\circ} \mathrm{C}$ por 8 minutos. Realizou-se, previamente, uma reação de RT-PCR com gradiente de temperaturas de anelamento para se obter a temperatura ideal. Os produtos de amplificação foram analisados por eletroforese em gel de poliacrilamida a 6\% corado com nitrato de prata, ou em gel de agarose a $2 \%$, corado com brometo de etídio. O tamanho do produto desta reação é de 130 pares de bases. 


\subsubsection{Conservação das Proteínas}

O material colhido foi transferido para tubo tipo eppendorf ao qual se adicionou 1 $\mathrm{mL}$ de tris-EDTA $(10 \mathrm{mM}-1 \mathrm{mM}), \mathrm{pH} 8,0$ para cada amostra e centrifugado a $2000 \times \mathrm{g}$, durante 15 minutos a $4^{\circ} \mathrm{C}$. A amostra foi lavada nestas condições três vezes consecutivas. Descartou-se o sobrenadante e foi adicionado $1 \mathrm{~mL}$ do tampão de lise de proteínas para cada $1 \mathrm{~g}$ de amostra e homogeneizou-se bem com a pipeta. O tampão de lise de proteínas é constituído por $200 \mu \mathrm{L}$ de $1 \mathrm{M}$ de Tris pH 7,5 (hidroximetilaminoetano);

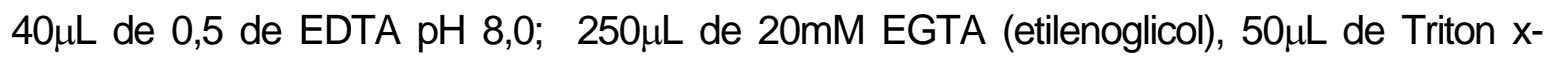
100, $9320 \mu$ l de $\mathrm{H} 2 \mathrm{O}$ q.s.p, $100 \mu \mathrm{L}$ de 200 PMSF (fluoreto de fenilmetilsulfonil), $20 \mu \mathrm{L}$ de $1 \mathrm{M}$ DTT (ditiotreitol), $10 \mu \mathrm{L}$ de $10 \mathrm{mg} / \mathrm{mL}$ aprotinina e $10 \mu \mathrm{l}$ de leupeptina $\mu \mathrm{g} / \mathrm{ml}$. Os últimos 4 reagentes só foram adicionados à solução de lise de proteínas no momento de transferência para a amostra. Incubou-se em gelo, durante pelo menos 30 minutos e congelou-se.

\subsubsection{Determinação da Concentração das Proteínas}

A concentração de proteínas totais foi determinada através da técnica descrita por Lowry (1951). Foram preparadas as seguintes soluções: solução $1(0,5 g$ de tartarato alcalino de sódio/potássio; $20 \mathrm{~g}$ de $\mathrm{Na}_{2} \mathrm{CO}_{3} ; 4,0 \mathrm{~g}$ de $\mathrm{NaOH} ;$ q.s.p. 1L); solução 2 (sulfato de cobre $0,1 \%$ ). O reativo Cupro-Alcalino foi preparado através da proporção 9:1(v/v) da solução 1 e solução 2 respectivamente. O reativo de FolinCiocalteau foi diluído 1:2 (v/v) em água deionizada. 
Para a elaboração de uma curva-padrão, albumina de soro bovino (BSA) foi preparada nas concentrações de 0, 1,5, 3 e $5 \mathrm{mg} / \mathrm{mL}$ em tampão de PBS (1,105 g de $\mathrm{Na}_{2} \mathrm{HPO}_{4} ; 0,302 \mathrm{~g}$ de $\mathrm{KH}_{2} \mathrm{PO}_{4} ; 8,1 \mathrm{~g}$ de $\mathrm{NaCl}$ e 0,2025 $\mathrm{g}$ de $\mathrm{KCl}$, q.s.p. $1000 \mathrm{~mL}$ ). Um $\mathrm{mL}$ do reativo cupro-alcalino foi adicionado a $20 \mu \mathrm{L}$ de padrão. Após 15 minutos, adicionou-se $200 \mu \mathrm{L}$ do reativo de Folin-Ciocalteau e incubou-se por 30 minutos no escuro à temperatura ambiente. As absorbâncias foram então determinadas em comprimento de onda de 750nm, utilizando-se um espectrofotômetro Beckman DU-70.

\subsubsection{Estudo da Expressão das Proteínas P-GP, MRP-1 E LRP POR “DOT BLOT”}

As amostras foram descongeladas à temperatura ambiente e centrifugadas à $12.000 \times \mathrm{g}$, durante 10 minutos a $4^{\circ} \mathrm{C}$. A concentração da proteína foi determinada de acordo com o método de Lowry.

Quantidades iguais de proteínas $(20 \mu \mathrm{g})$ foram transferidas para membrana de PVDF através do sistema "Slot Blot" (Pharmacia, Hoefer). A membrana foi pré-tratada com metanol durante 5 segundos, água por 5 minutos e PBS por 15 minutos. Em seguida a membrana foi bloqueada com solução contendo soroalbumina bovina 3\% (BSA 3\%) e leite em pó desnatado 2\% em TBS, durante 1 hora. Lavou-se com TBS contendo Tween 20 0,1\% 2 vezes rapidamente, 1 vez durante 15 minutos e 2 lavagens de 5 minutos cada. Retirou-se a solução de lavagem e adicionou-se o anticorpo primário $(2 \mu \mathrm{g} / \mathrm{mL})$ em soluçãoTBS/Tween 20 por 1 hora, em temperatura ambiente em agitador. Lavou-se com TBS contendo 0,1\% Tween 20, 2 vezes rapidamente, 1 vez durante 15 minutos e 2 
lavagens de 5 minutos cada. Incubou-se a membrana com anticorpo secundário (1:600) marcado com fluoresceína, diluído em solução TBS/Tween 20 0,1\% por uma hora à temperatura ambiente, em agitador. Repetiu-se o esquema das lavagens anteriores como descrito. A membrana foi incubada com o conjugado de fosfatase alcalina antifluoresceína (1:2500) diluída em TBS/Tween 20 0,1\%, durante 1 hora à temperatura ambiente, em câmara escura, em agitador. Lavou-se com TBS contendo 0,1\% Tween 20, 2 vezes rapidamente, 1 vez durante 15 minutos e 2 lavagens de 5 minutos cada. Incubouse a membrana com a solução de substrato ECF (Amersham Biosciences), à tempreratura ambiente, em câmara escura durante 20 minutos e por fim, deixou-se a membrana secar em papel filtro Whatman 3MM, à temperatura ambiente, em câmara escura por 20 minutos. As proteínas que reagiram com anticorpo foram visualizadas em sistema de análise de STORM 840.

Foram utilizados anticorpos monoclonais JSB-1 e anti-MRP1, ambos produzidos pela Zymed Laboratories Inc., para a detecção da P-gp e MRP1 respectivamente. Em relação à detecção da LRP, utilizou-se o anticorpo monoclonal LRP-56 (Signet). 


\section{$4 \quad$ RESULTADOS}

\subsection{CASUÍSTICA}

A média de idade dos animais com linfoma multicêntrico incluídos nesse estudo foi de 7 anos. Foram avaliados sete machos e oito fêmeas, sendo dois animais da raça cocker spaniel, dois da raça boxer, dois da raça rottweiler, dois da raça dobermann, um poodle, um bassethound, um pastor alemão, um whippet, um bulldog, um pit bull e um cão sem raça definida (Quadro 4.1).

Em relação à avaliação citológica, a maioria foi classificada como Linfoma Linfoblástico, representando 60\% (9/15), seguida pelo Linfoma Linfocítico de Pequenas Células 26,6\% (4/15), Difuso Misto de Grandes e Pequenas Células 6,7\% (1/15) e pelo Difuso de Grandes Células 6,7\% (1/15), conforme quadro 4.1.

Todo os cães apresentaram ao exame físico linfoadenomegalia periférica, e a maioria foi classificada nos estadios IV ou V, subestadio (b), representando $80 \%$ (12/15) do total, seguidos por $13,3 \%(2 / 15)$ com estadio III (a) e um caso $(6,7 \%)$ com classificação III ou IV (b) (Quadro 4.1).

Dentre os 15 animais, nove foram submetidos ao protocolo COP e seis ao VCM (Quadro 4.1). A freqüência de remissão completa foi de 66.7\% (10/15) e a de remissão parcial 33.3\% (5/10), de forma igual com o uso de ambos os protocolos (Quadro 4.1).

No geral, a média de duração da remissão foi de 108 dias e a média da sobrevida de 240 dias (Quadro 4.1), 76 e 155 dias e 183 e 328 dias para os protocolos COP e VCM respectivamente (Quadro 4.1). As características gerais dos quinze cães estudados estão dispostas no quadro 4.1. 


\begin{tabular}{|c|c|c|c|c|c|c|c|c|c|c|c|}
\hline ID & RAÇA & IDADE & SEXO & CITOLOGIA & ESTADIO & PROT & INÍCIO QT & REMISSÃO 1 & REMISSÃO 2 & RECIDIVA & SOBREVIDA \\
\hline 01 & Cocker Spaniel & $6 \mathrm{~A}$ & $\mathrm{~F}$ & Linfoblástico & III (a) & VCM & $19 / 03 / 03$ & Completa & $270 d$ & $16 / 12 / 03$ & 529d \\
\hline 02 & Dobermann & $5 A$ & $F$ & Dif. Gdes. Céls. & IV ou V (b) & COP & $17 / 04 / 03$ & Completa & 90d & $10 / 07 / 03$ & $365 d$ \\
\hline 03 & Poodle & $14 \mathrm{~A}$ & $\mathrm{M}$ & Linfoblástico & III ou IV (b) & COP & $17 / 04 / 03$ & Completa & $60 d$ & $03 / 06 / 03$ & 90d \\
\hline 04 & Pit Bull & $6 A$ & $\mathrm{M}$ & Linfoblástico & IV ou V (b) & COP & $22 / 05 / 03$ & Parcial & $30 d$ & $25 / 06 / 03$ & 100d \\
\hline 05 & Dobermann & $6 \mathrm{~A}$ & $\mathrm{~F}$ & Linfoblástico & IV ou V (b) & COP & $02 / 06 / 03$ & Completa & $45 d$ & $19 / 08 / 03$ & 180d \\
\hline 06 & Boxer & $7 \mathrm{~A}$ & $\mathrm{M}$ & Linfoc. Peqn. & IV ou V (b) & $\mathrm{COP}$ & $02 / 06 / 03$ & Completa & $80 d$ & $19 / 08 / 03$ & $110 d$ \\
\hline 07 & Cocker Spaniel & $10 \mathrm{~A}$ & $\mathrm{M}$ & Linfoc. Peqn. & IV ou V (b) & VCM & 03/06/03 & Parcial & $40 d$ & $10 / 07 / 03$ & 90d \\
\hline 08 & Bulldog & $7 \mathrm{~A}$ & $\mathrm{M}$ & Linfoblástico & IV ou V (b) & VCM & $09 / 06 / 03$ & Parcial & $50 d$ & $30 / 07 / 03$ & 90d \\
\hline 09 & Boxer & $9 A$ & $\mathrm{~F}$ & Linfoblástico & III (a) & COP & $17 / 06 / 03$ & Parcial & $30 d$ & $20 / 07 / 03$ & $45 d$ \\
\hline 10 & Rottweiler & $5 A$ & $\mathrm{~F}$ & Linfoblástico & IV ou V (b) & VCM & $07 / 07 / 03$ & Completa & $120 d$ & $10 / 11 / 03$ & $402 d$ \\
\hline 11 & Bassethound & $7 \mathrm{~A}$ & $\mathrm{M}$ & Linfoc. Peqn. & IV ou V (b) & VCM & $08 / 07 / 03$ & Completa & $240 d$ & $03 / 03 / 04$ & $450 d$ \\
\hline 12 & Rottweiler & $4 \mathrm{~A}$ & $\mathrm{~F}$ & Linfoblástico & IV ou V (b) & COP & $14 / 08 / 03$ & Completa & 40d & $25 / 09 / 03$ & $270 d$ \\
\hline 13 & Pastor Alemão & $2 \mathrm{~A}$ & $\mathrm{M}$ & Dif. Gdes. Peqn. & IV ou V (b) & COP & 01/09/03 & Parcial & 100d & $15 / 12 / 03$ & 150d \\
\hline 14 & Sem raça & $6 \mathrm{~A}$ & $\mathrm{~F}$ & Linfoc.Peqn. & IV ou V (b) & COP & 10/09/03 & Completa & $210 \mathrm{~d}$ & 29/04/04 & 330d \\
\hline 15 & Whippet & $11 \mathrm{~A}$ & $\mathrm{~F}$ & Linfoblástico & IV ou V (b) & VCM & 03/11/03 & Completa & $210 d$ & $10 / 06 / 04$ & $405 d$ \\
\hline
\end{tabular}

Legenda: Linfoc. Peqn - Linfoma Linfocítico de Pequenas Células, Dif. Gdes. Céls. - Linfoma Difuso de Grandes Células, Dif. Gdes. Peqn. - Linfoma Difuso Misto de Grandes e Pequenas Células.

Quadro 4.1 - Caracterização dos cães com linfoma multicêntrico segundo identificação (ID), definição racial, idade, sexo, classificação citológica segundo "Working Formulation" (1982), estadio, protocolo quimioterápico (PROT), início da quimioterapia (QT), tipo de remissão (Remissão 1), duração da remissão (Remissão 2), recidiva e sobrevida, atendidos no HOVET-FMVZ/USP, São Paulo - no período de março/03 setembro/04 


\subsection{ANÁLISE DA RESISTÊNCIA A MÚLTIPLAS DROGAS POR BIOLOGIA MOLECULAR}

\subsubsection{Extração de RNA}

Foram extraídos RNAs totais das amostras colhidas previamente à quimioterapia $(A)$ e na recidiva do processo tumoral $(P)$. Observou-se que todas as amostras apresentaram RNA, indicado pela presença das bandas $28 \mathrm{~S}$ e $18 \mathrm{~S}$, e foram passíveis portanto, de amplificação por RT-PCR (Figura 4.1).

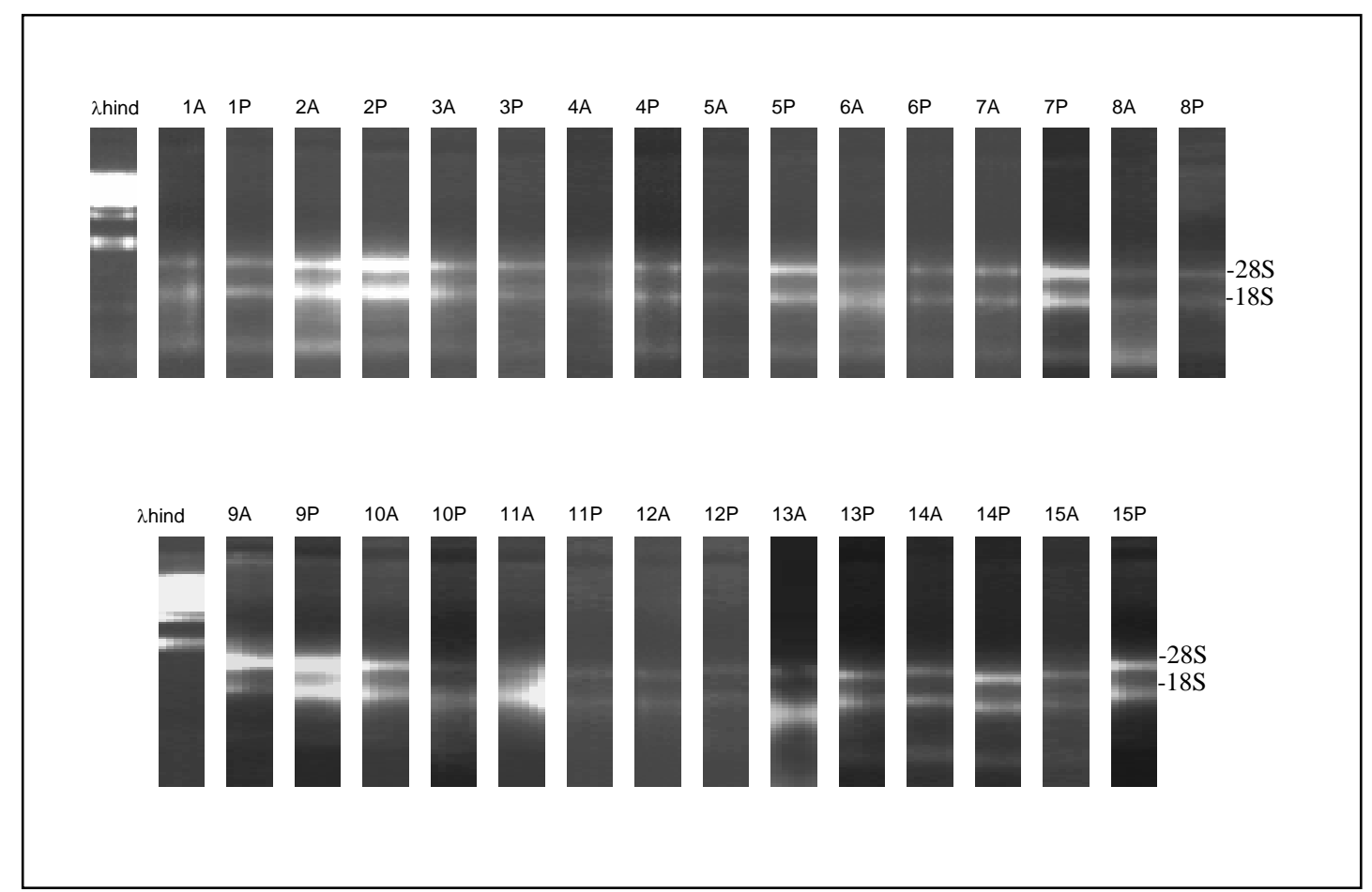

Figura 4.1 - Eletroforese em gel de agarose 1\% corado com brometo de etídio dos RNAs totais de cães com linfoma multicêntrico ao diagnóstico $(A)$ e na recidiva $(P)$ 


\subsubsection{Quantificação dos RNAs}

As amostras de RNA foram determinadas em "GeneQuant ${ }^{\circledR "}$ por espectrofotometria em luz ultra-violeta nos comprimentos de onda 260 e $280 \mathrm{~nm}$, obtendo-se concentração em $\mu \mathrm{g} / \mathrm{mL}$, absorbância em nm, pureza em \% e razão de RNA. A razão representa a relação entre a absorbância obtida a 260 nm e 280nm (Quadro 4.2).

\begin{tabular}{|c|c|c|c|c|}
\hline AMOSTRA & {$[$ ] } & ABS & \% & R \\
\hline $01 \mathrm{~A}$ & 0.5 & 0.013 & 140 & 2.525 \\
\hline $01 \mathrm{P}$ & 0.9 & 0.021 & 77 & 1.391 \\
\hline $02 \mathrm{~A}$ & 1.2 & 0.031 & 113 & 2.049 \\
\hline $02 \mathrm{P}$ & 0.9 & 0.022 & 152 & 2.745 \\
\hline $03 \mathrm{~A}$ & 0.9 & 0.022 & 115 & 2.084 \\
\hline $03 \mathrm{P}$ & 0.4 & 0.009 & 174 & 3.140 \\
\hline $04 \mathrm{~A}$ & 1.2 & 0.030 & 75 & 1.350 \\
\hline $04 \mathrm{P}$ & 0.3 & 0.007 & 360 & 6.486 \\
\hline $05 \mathrm{~A}$ & 1.1 & 0.028 & 94 & 1.693 \\
\hline $05 \mathrm{P}$ & 0.3 & 0.007 & 190 & 1.522 \\
\hline $06 \mathrm{~A}$ & 0.2 & 0.005 & 64 & 1.163 \\
\hline $06 \mathrm{P}$ & 0.3 & 0.008 & 91 & 1.640 \\
\hline $07 \mathrm{~A}$ & 0.5 & 0.012 & 79 & 1.425 \\
\hline $07 \mathrm{P}$ & 0.4 & 0.011 & 99 & 1.793 \\
\hline $08 \mathrm{~A}$ & 0.2 & 0.006 & 130 & 2.350 \\
\hline $08 \mathrm{P}$ & 0.5 & 0.012 & 80 & 1.443 \\
\hline $09 \mathrm{~A}$ & 0.4 & 0.009 & 69 & 1.258 \\
\hline $09 \mathrm{P}$ & 0.6 & 0.015 & 82 & 1.487 \\
\hline $10 \mathrm{~A}$ & 0.9 & 0.022 & 90 & 1.635 \\
\hline $10 \mathrm{P}$ & 0.3 & 0.007 & 128 & 2.310 \\
\hline $11 \mathrm{~A}$ & 0.5 & 0.012 & 93 & 1.690 \\
\hline $11 \mathrm{P}$ & 1.2 & 0.029 & 105 & 1.898 \\
\hline $12 \mathrm{~A}$ & 0.7 & 0.017 & 102 & 1.847 \\
\hline $12 \mathrm{P}$ & 0.2 & 0.005 & 101 & 1.819 \\
\hline $13 \mathrm{~A}$ & 0.9 & 0.022 & 101 & 1.818 \\
\hline $13 \mathrm{P}$ & 3.1 & 0.076 & 90 & 1.636 \\
\hline $14 \mathrm{~A}$ & 1.0 & 0.027 & 120 & 1.557 \\
\hline $14 \mathrm{P}$ & 4.2 & 0.078 & 97 & 1.485 \\
\hline $15 \mathrm{~A}$ & 0.9 & 0.023 & 84 & 1.519 \\
\hline $15 \mathrm{P}$ & 0.3 & 0.008 & 156 & 2.817 \\
\hline
\end{tabular}

Legenda : A - ao diagnóstico, P- na recidiva

Quadro 4.2 - Distribuição do RNAs amostrais de 15 cães com linfoma multicêntrico, segundo concentração ([ ]) em $\mu \mathrm{g} / \mathrm{ml}$, absorbância (ABS), pureza (\%) e razão (R). Laboratório de Hematologia Molecular, LIM-31, FMUSP, São Paulo - março/03 a setembro/04 


\subsubsection{Determinação da Concentração das Proteínas}

A concentração de proteínas totais foi determinada pelo método de Lowry, em todas as amostras. O procedimento utilizado foi aquele descrito em Material e Métodos. As concentrações de proteínas foram calculadas através da utilização da curva-padrão (Figura 4.2).

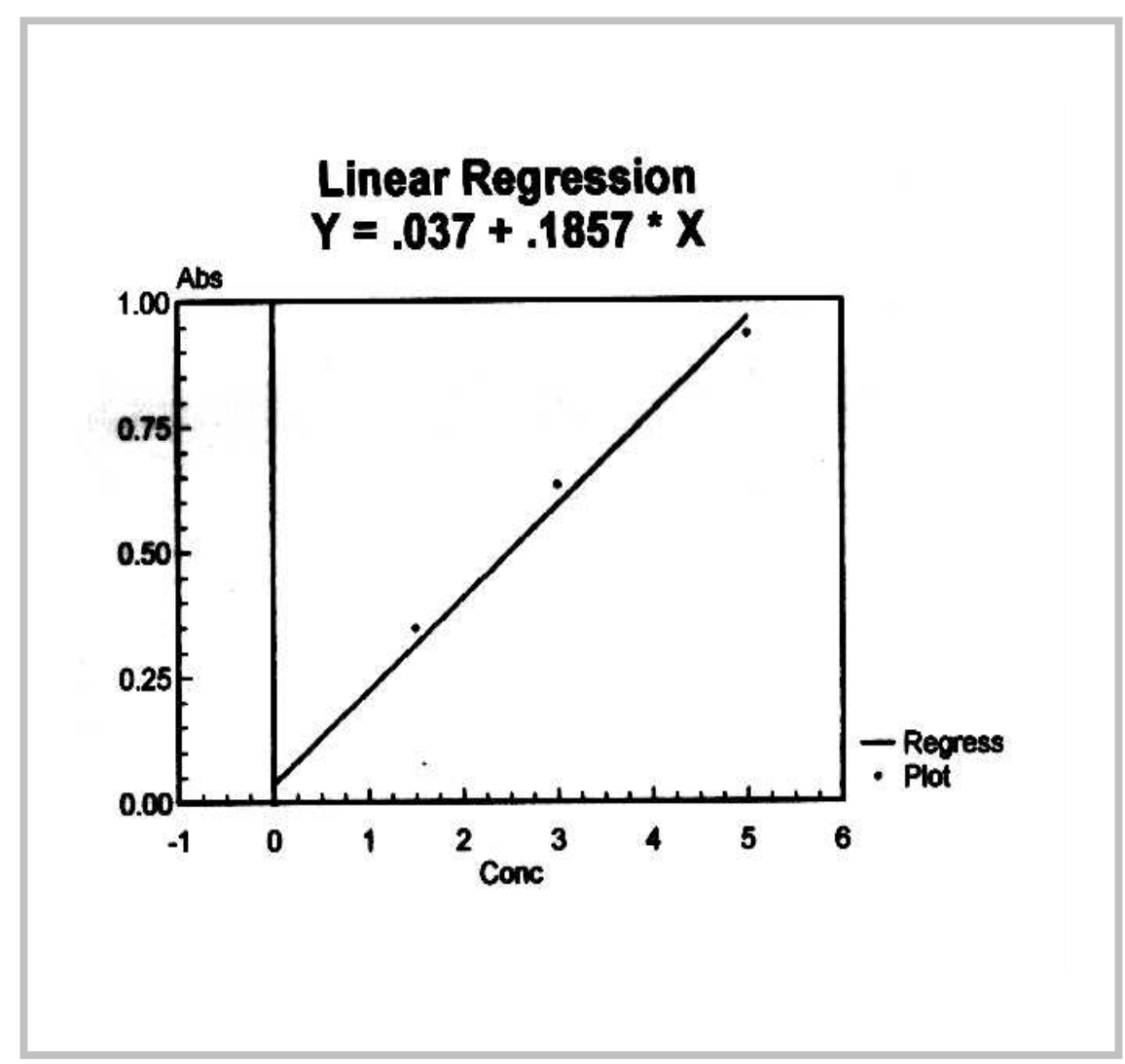

Figura 4.2 - Curva padrão típica de dosagem de proteína pelo método Lowry

O quadro a seguir mostra os resultados obtidos. Desta forma, foi possível realizar a técnica de "Dot Blot" para detecção da Pgp, MRP e LRP, pois todas as amostras apresentaram concentrações desejáveis de proteínas. Não foi colhido 
material para análise protéica da amostra 1 ao diagnóstico, e por isso esta não foi submetida ao "Dot Blot".

\begin{tabular}{|c|c|c|c|c|}
\hline $\mathbf{N}^{\mathbf{O}}$ & AMOSTRA & [X1 ] & [ X2 ] & [ XM ] \\
\hline 1 & 01P & 0.6750 & 0.5219 & 0.59845 \\
\hline 2 & 02A & 0.5681 & 0.5911 & 0.5796 \\
\hline 3 & 02P & 0.4205 & 0.4426 & 0.43155 \\
\hline 4 & 03A & 0.5407 & 0.7051 & 0.6229 \\
\hline 5 & 03P & 0.2711 & 0.4130 & 0.34205 \\
\hline 6 & 04A & 0.5177 & 0.5723 & 0.545 \\
\hline 7 & 04P & 0.5518 & 0.6883 & 0.62005 \\
\hline 8 & $05 A$ & 0.5822 & 0.6096 & 0.5959 \\
\hline 9 & 05P & 0.4879 & 0.3923 & 0.4401 \\
\hline 10 & $06 \mathrm{~A}$ & 0.1244 & 0.2446 & 0.1845 \\
\hline 11 & 06P & 1.315 & 1.315 & 1.315 \\
\hline 12 & 07A & 0.3887 & 0.4400 & 0.41435 \\
\hline 13 & 07P & 0.3666 & 0.4771 & 0.42185 \\
\hline 14 & $08 \mathrm{~A}$ & 0.4956 & 0.5176 & 0.5066 \\
\hline 15 & 08P & 0.2747 & 0.2784 & 0.27655 \\
\hline 16 & 09A & 0.2473 & 0.3454 & 0.29635 \\
\hline 17 & 09P & 0.2559 & 0.3118 & 0.28385 \\
\hline 18 & $10 \mathrm{~A}$ & 0.3971 & 0.3551 & 0.3761 \\
\hline 19 & 10P & 0.2654 & 0.3339 & 0.29965 \\
\hline 20 & $11 \mathrm{~A}$ & 0.5679 & 0.7776 & 0.67275 \\
\hline 21 & $11 \mathrm{P}$ & 0.4187 & 0.3330 & 0.37585 \\
\hline 22 & $12 \mathrm{~A}$ & 1.032 & 1.092 & 1.062 \\
\hline 23 & $12 \mathrm{P}$ & 0.1593 & 0.1987 & 0.175 \\
\hline 24 & $13 \mathrm{~A}$ & 0.7157 & 0.7522 & 0.73395 \\
\hline 25 & $13 \mathrm{P}$ & 0.8403 & 1.012 & 0.92615 \\
\hline 26 & $14 \mathrm{~A}$ & 0.3892 & 0.3816 & 0.3854 \\
\hline 27 & 14P & 3.635 & 3.310 & 3.4725 \\
\hline 28 & $15 \mathrm{~A}$ & 0.5754 & 0.6247 & 0.60005 \\
\hline 29 & $15 \mathrm{P}$ & 0.5584 & 0.6432 & 0.6008 \\
\hline
\end{tabular}

Legenda: $\mathrm{A}$ - ao diagnóstico, $\mathrm{P}$ - na recidiva

Quadro 4.3 - Distribuição das amostras de 15 cães com linfoma multicêntrico, segundo as concentrações proteicas mensuradas em duplicata $([x 1]$ e [x2]) e o valor médio $([\mathrm{xM}])$, em $\mathrm{mg} / \mathrm{ml}$, por espectrofotômetro, pelo método de Lowry. Laboratório de Hematologia Molecular, LIM-31, FMUSP, São Paulo - março/03 a setembro/04 


\subsubsection{Estudo da Expressão do Gene MDR-1}

\subsubsection{RT-PCR}

Foi necessário a adequação das condições de temperatura de anelamento para a reação de RT-PCR, com a finalidade de verificar a expressão do gene MDR1. A figura 4.3 mostra a foto do gel de agarose a $2 \%$, da curva construída para análise da temperatura de anelamento ótima.

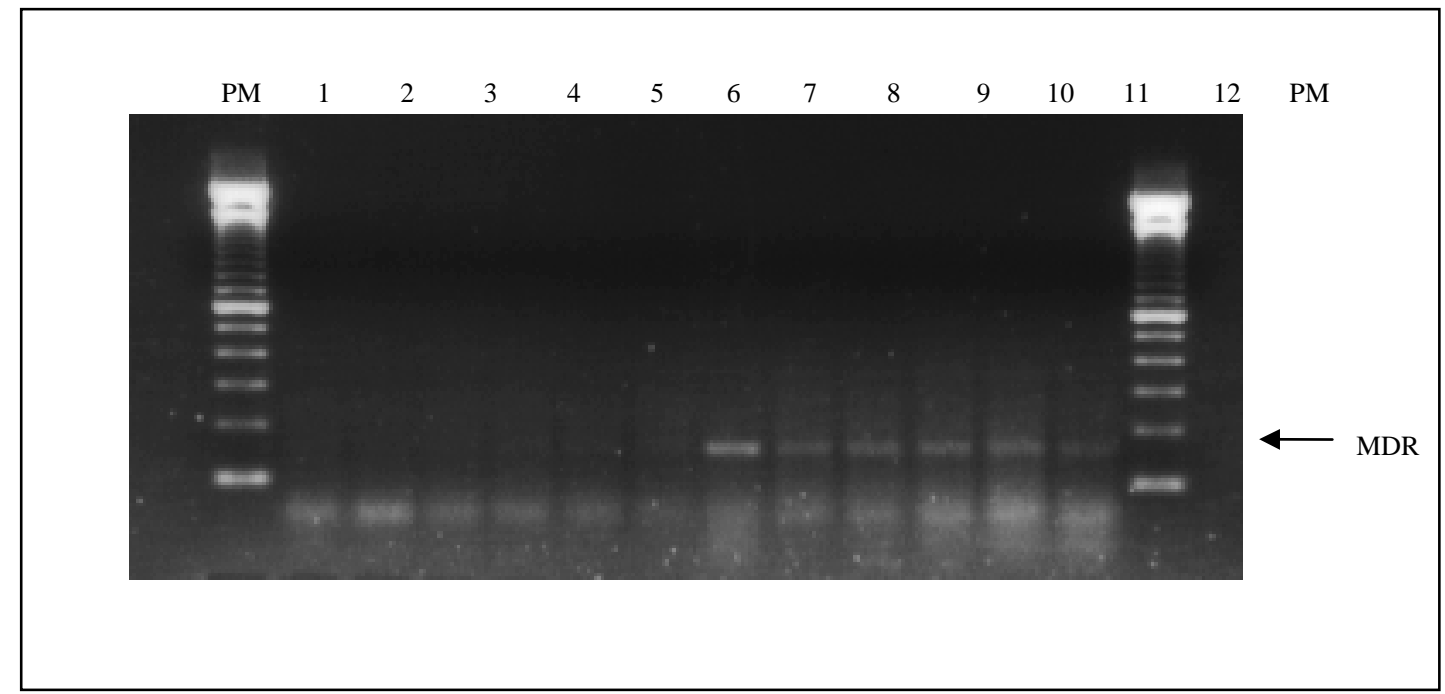

Figura 4.3 - Curva de temperaturas de anelamento para reação de RT-PCR de MDR-1 em gel de agarose $2 \%$ corado com brometo de etídio (PM: padrão de peso molecular; 1: $50^{\circ} \mathrm{C}$; 2: $50,4^{\circ} \mathrm{C} ; 3: 51,2^{\circ} \mathrm{C} ; 4: 52,5^{\circ} \mathrm{C}$; $5: 53,2^{\circ} \mathrm{C} ; 6: 54,6^{\circ} \mathrm{C} ; 7$ : $55^{\circ} \mathrm{C}$; 8: $55,8^{\circ} \mathrm{C}$; 9: $56,4^{\circ} \mathrm{C} ; 10: 57,8^{\circ} \mathrm{C} ; 11: 58,9^{\circ} \mathrm{C} ; 12: 60^{\circ} \mathrm{C}$ ) de cão com linfoma multicêntrico

Conforme observado, a melhor temperatura de anelamento para esta amplificação foi $55^{\circ} \mathrm{C}$. Foi então realizado RT-PCR das amostras de RNA obtidas dos linfonodos caninos (Figura 4.4). Células de sarcoma uterino humano resistentes à doxorrubicina, foram utilizadas como controle positivo para a reação. 


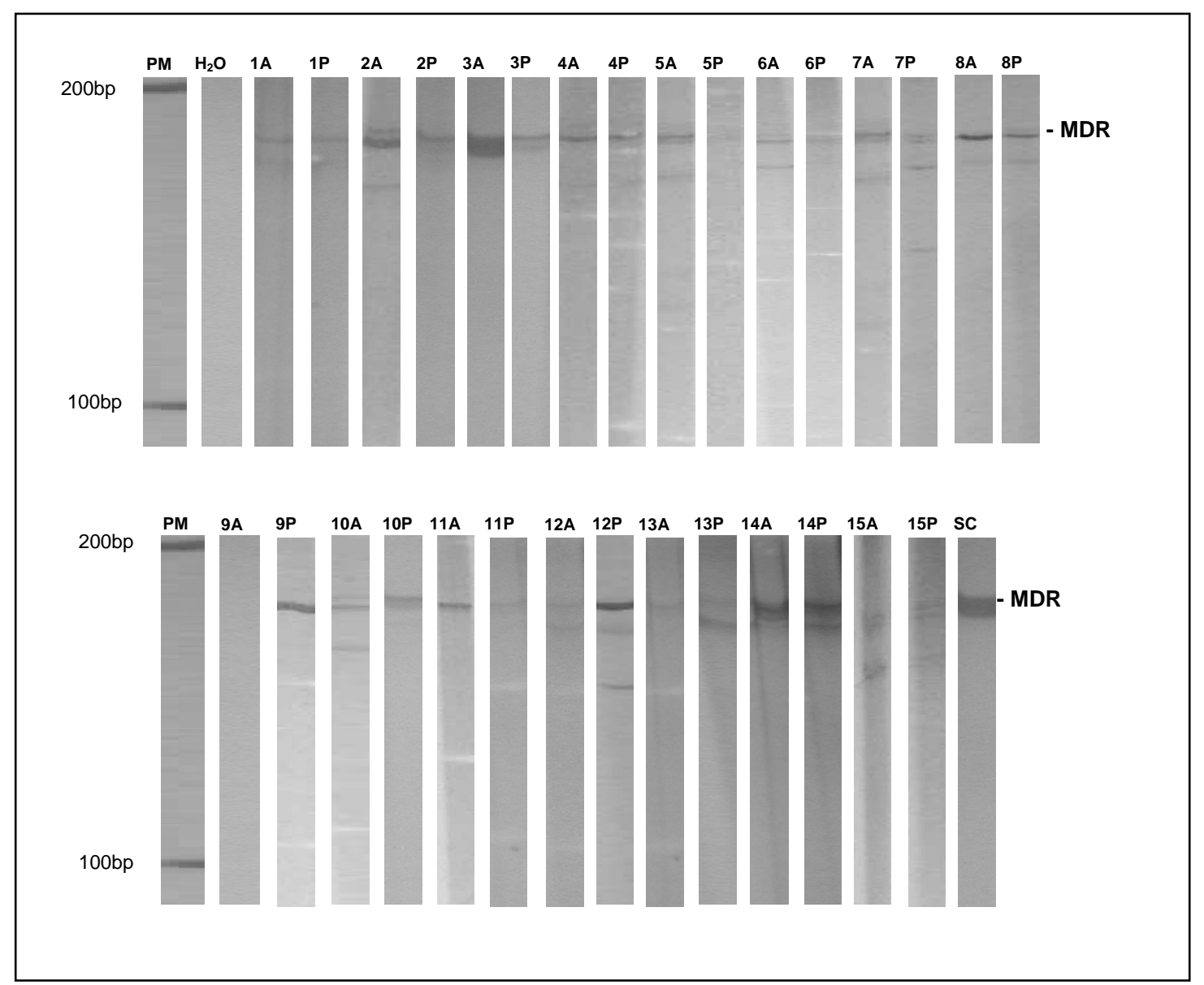

Figura 4.4 - Eletroforese em gel de poliacrilamida a 6\% corado com prata da reação de RTPCR para detecção do gene MDR-1em cães com linfoma multicêntrico. PM: padrão de peso molecular de 100bp; A: previamente a quimioterapia; P: recidiva do linfoma

Os cães $1,2,3,4,5,6,7,8,10,11,12,13,14$ e 15 expressaram o gene MDR-1, previamente à quimioterapia, o que foi verificado pela presença da banda na posição de $147 \mathrm{bp}$, conforme indicado na figura 4.4. Isto representou uma freqüência de 93,3\% (14/15) de casos positivos para o MDR-1 ao diagnóstico (Tabela 4.1)

Durante a recidiva tumoral, esta freqüência aumentou para 100\% (15/15), pois o cão 9 tornou-se positivo para o MDR-1. Assim, a freqüência de expressão intrínseca para o gene MDR-1 nos animais estudados foi 93,3\% (14/15) e a de expressão adquirida $6,7 \%(1 / 15)$, conforme tabela 4.1 . 
Nota-se também, pela figura 4.4 , que os cães identificados como $2 \mathrm{~A}, 5 \mathrm{~A}, 5 \mathrm{P}$ e 13A apresentaram alterações na banda correspondente ao gene MDR-1, indicando a possível presença de polimorfismos de MDR-1.

\subsubsection{Expressão da P-gp por "Dot Blot"}

Foi realizada curva de titulação do anticorpo primário para se atingir uma titulação ideal para cada um, na qual, a menor concentração de anticorpo foi capaz de gerar um sinal. O título ideal para o anticorpo anti-Pgp foi 8000 conforme mostra a figura 4.5. Células de sarcoma uterino humano resistentes à doxorrubicina foram utilizadas como controle positivo da reação.

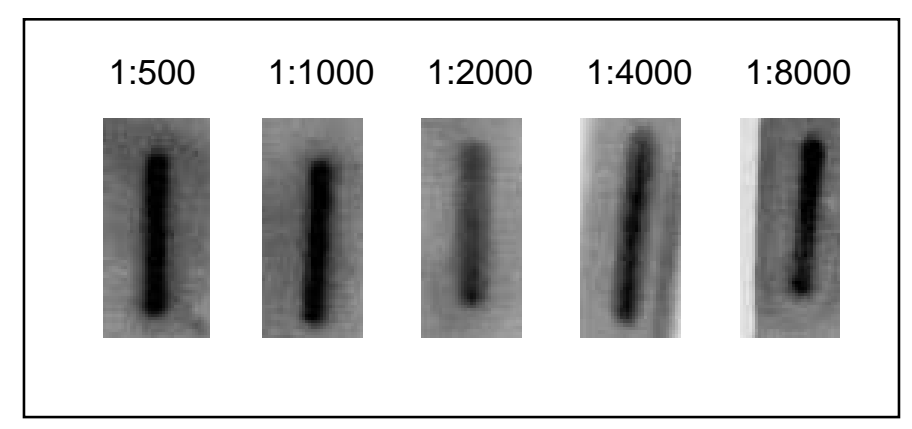

Figura 4.5 - Titulação do anticorpo primário anti-Pgp

Os cães 2, 3, 4, 5, 7, 8, 10,11,12, 13, 14 e 15 expressaram a P-gp previamente à quimioterapia, conforme figura 4.6, indicando uma freqüência (tabela 4.1) de expressão ao diagnóstico 85,8\% (12/14). Durante a recidiva, esta freqüência (Tabela 4.1) elevou-se para 92,9\% (13/14), pois o cão 6 tornou-se positivo, enquanto o cão 9 não expressou a P-gp nestes dois momentos, como demonstrado na figura 4.6. Foi utilizada célula de sarcoma uterino resistente à doxorrubicina como controle positivo. 
Desta forma, a freqüência de expressão intrínseca da P-gp (Tabela 4.1) nos cães estudados foi $85,8 \%$ (12/14) e a de expressão adquirida (Tabela 4.1) foi de 7,1\% (13/14). O cão 9 não expressou a P-gp, representando uma freqüência de $7,1 \%(1 / 14)$.

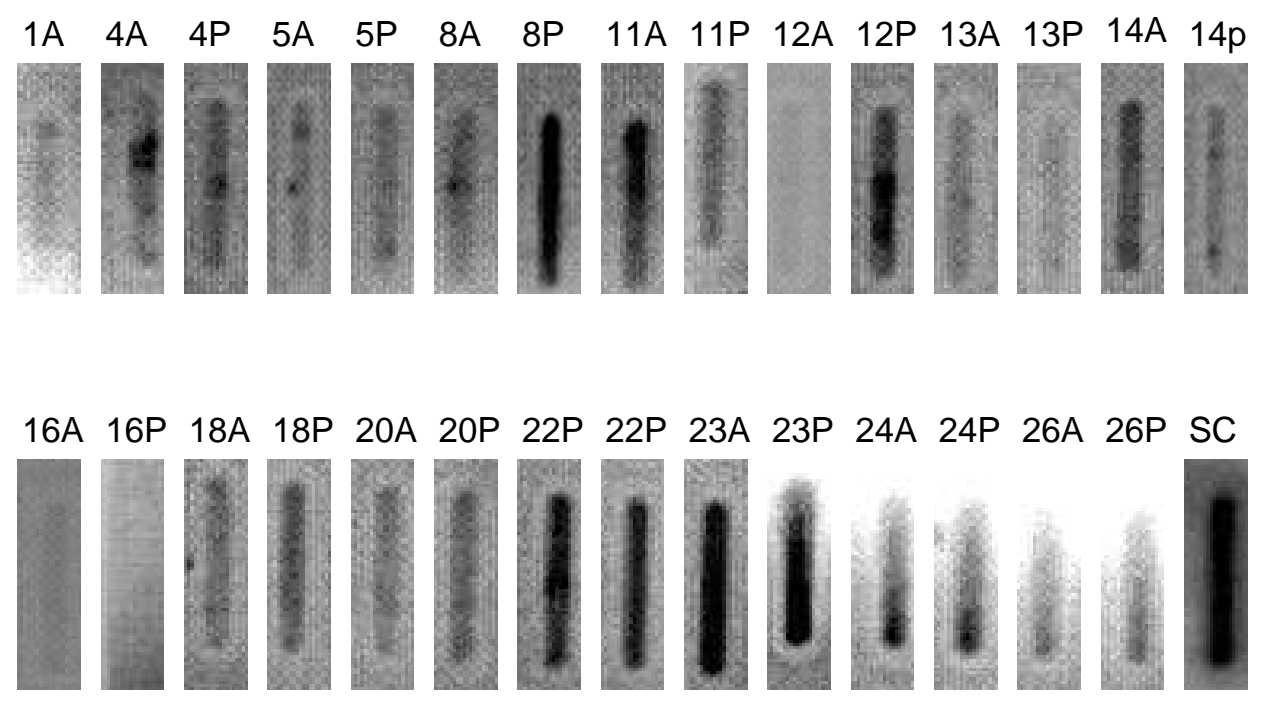

Figura 4.6 - "Slot Dot" anti-Pgp em membrana de PVDF em cães com linfoma multicêntrico. A: previamente a quimioterapia; P: recidiva do linfoma; SC: sarcoma uterino resistente à doxorrubicina

\subsubsection{Estudo da Expressão do Gene MRP}

\subsubsection{RT-PCR}

A temperatura de anelamento utilizada foi descrita por Zhan et al. (1997).

Desta forma, foi realizado o RT-PCR das amostras conforme mostra a figura 4.7. Células de sarcoma uterino humano resistentes à doxorrubicina foram utilizadas como controle positivo para a reação. 


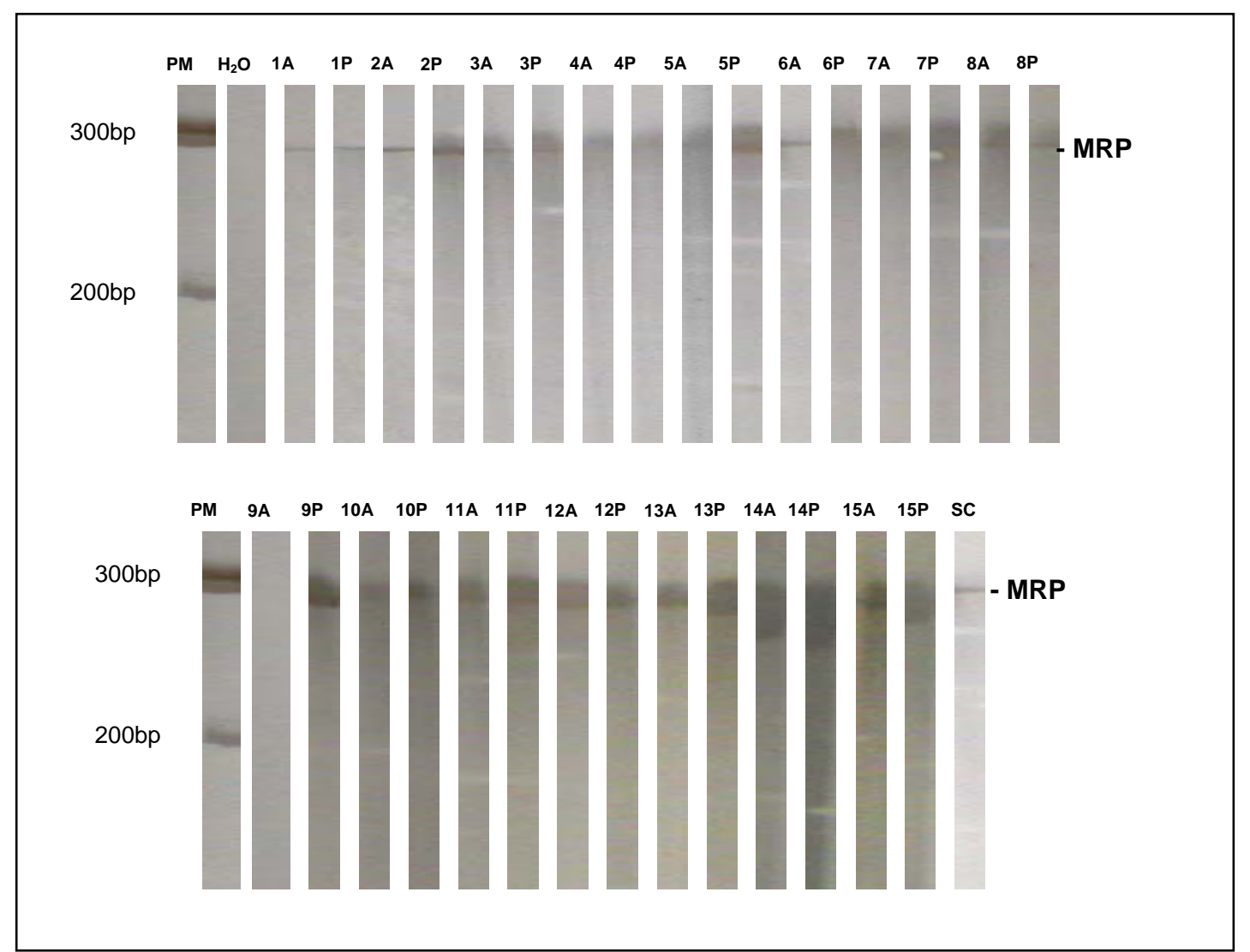

Figura 4.7 - Eletroforese em gel de poliacrilamida a 6\% corado com prata da reação de RTPCR para detecção do gene MRP em cães com linfoma multicêntrico. PM: padrão de peso molecular de 100bp; A: previamente a quimioterapia; $\mathbf{P}$ : recidiva do linfoma

Durante o diagnóstico, os cães 1, 2, 3, 4, 5, 6, 7, 8, 10, 11, 12, 13, 14 e 15 expressaram o gene MRP-1, representado pela presença de banda na posição 295 bp, conforme figura 4.7. A freqüência da expressão do gene MRP-1 nos animais estudados ao diagnóstico (Tabela 4.1), foi 93,3\% (14/15) e subiu para 100\% (15/15) durante a recidiva tumoral (Tabela 4.1), quando o cão 9 tornou-se positivo para este gene (Figura 4.7).

Desta forma, a freqüência de expressão intrínseca para o gene MRP-1 nesta população, foi 93,3\% (14/15) e a de expressão adquirida 6,7\% (1/15), conforme tabela 4.1. 


\subsubsection{Expressão da MRP por "Dot Blot"}

Foi realizada curva de titulação do anticorpo primário para se atingir uma titulação ideal, na qual, a menor concentração de anticorpo foi capaz de gerar um sinal. O título ideal para o anticorpo anti-MRP foi 2000 conforme mostra a figura 4.8. Células de sarcoma uterino humano resistentes à doxorrubicina, foram utilizadas como controle positivo da reação.

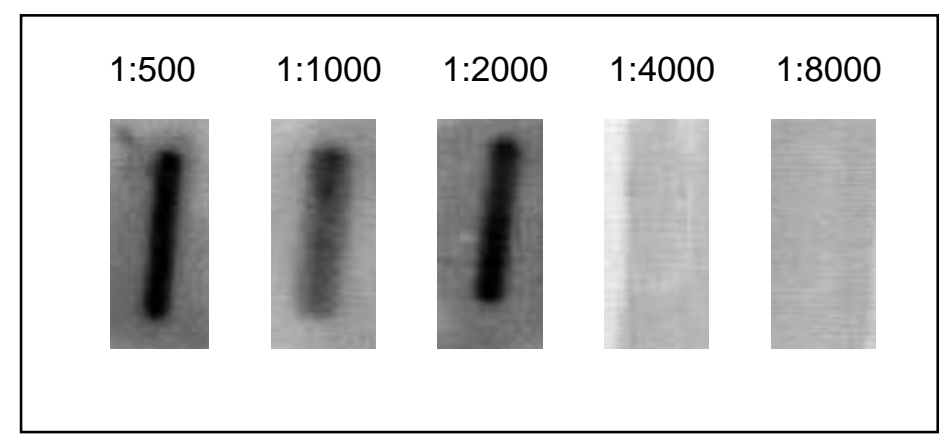

Figura 4.8 -Titulação do anticorpo primário anti-MRP

Durante o diagnóstico, os cães 2, 3, 4, 5, 8, 10, 12, 13, 14 e 15 expressaram a proteína MRP, conforme figura 4.9, indicando uma freqüência ao diagnóstico de 71,5\% (10/14), conforme tabela 4.1. Na recidiva, esta freqüência (Tabela 4.1) atingiu 92,9\% (13/14), pois os cães 6, 9 e 11, inicialmente negativos tornaram-se positivos, enquanto que o cão 7 permaneceu negativo, conforme figura 4.9.

Assim, a freqüência de expressão intrínseca da MRP nos cães estudados foi de $71,5 \%$ (10/14) e a de expressão adquirida de 21,4\% (3/14), conforme tabela 4.1 . 


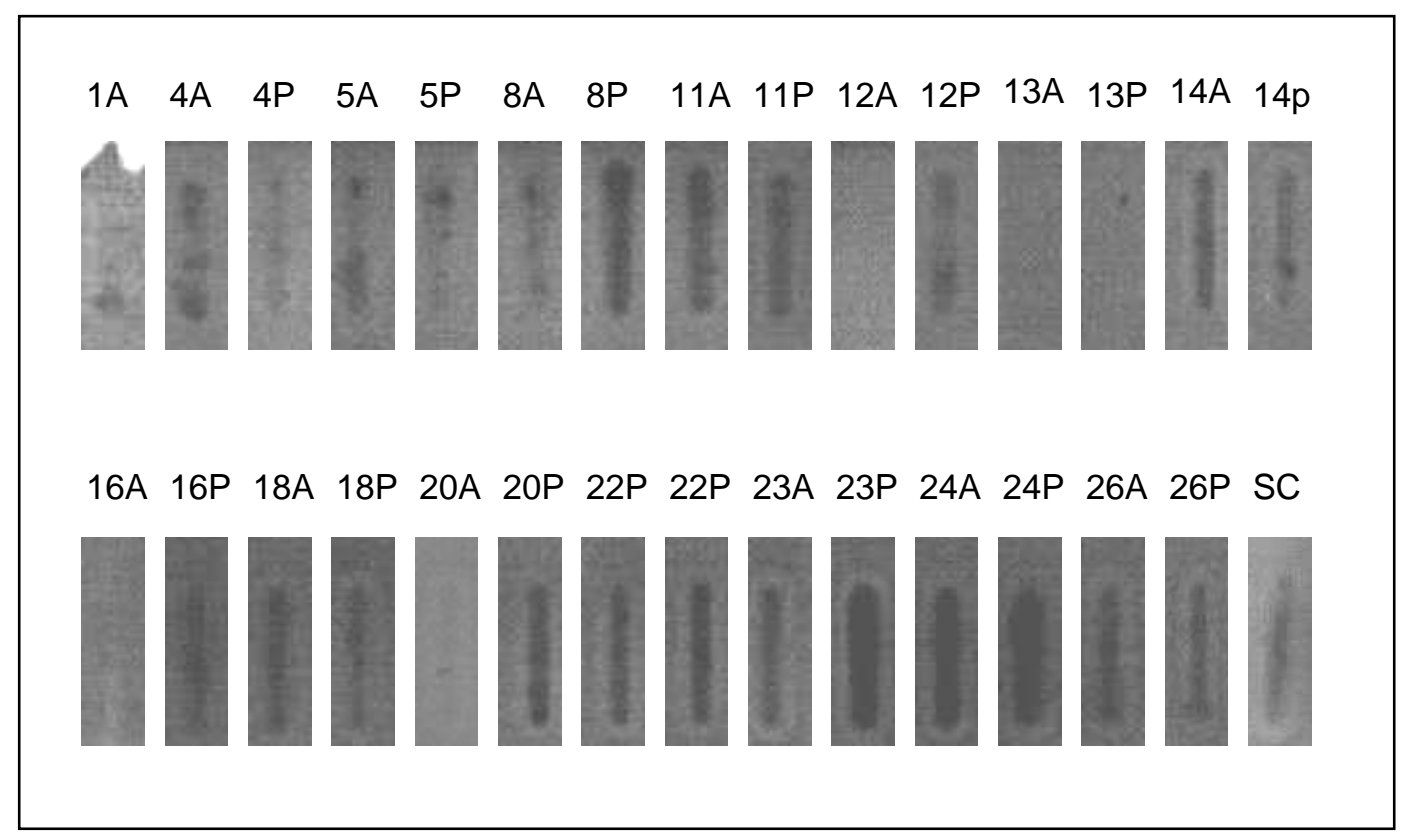

Figura 4.9 -"Slot Dot" anti-MRP em membrana de PVDF de cães com linfoma multicêntrico. A: previamente a quimioterapia; P: recidiva do linfoma; SC: sarcoma uterino resistente à doxorrubicina

\subsubsection{Estudo da Expressão do Gene LRP}

\subsubsection{RT-PCR}

A figura 4.10 indica que a temperatura ótima para o anelamento da reação de RT-PCR de LRP foi $52.2^{\circ} \mathrm{C}$, obtida por uma reação de RT-PCR com gradiente de temperatura. Células de sarcoma uterino humano resistentes à doxorrubicina foram utilizadas como controle positivo da reação.

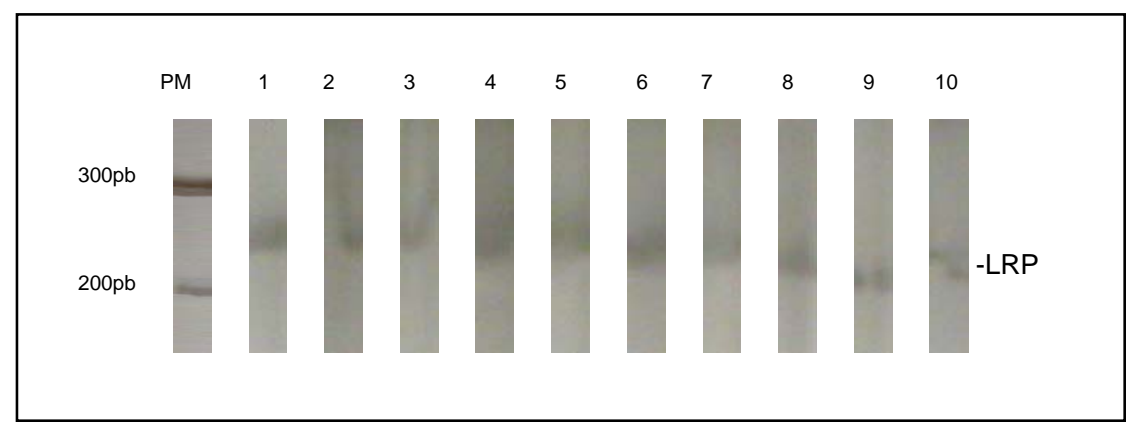

Figura 4.10 - Curva de temperaturas de anelamento para reação de RTPCR para detecção do gene LRP em cão com linfoma multicêntrico, em gel de poliacrilamida $6 \%$ corado com prata. PM: padrão de peso molecular de $100 \mathrm{bp} ; 1: 51,2^{\circ} \mathrm{C}$; 2: $51,4^{\circ} \mathrm{C} ; 3: 51,6^{\circ} \mathrm{C} ; 4: 51,8^{\circ} \mathrm{C} ; 5: 52^{\circ} \mathrm{C} ; 6: 52,2^{\circ} \mathrm{C} ; 7$ : $52,4^{\circ} \mathrm{C} ; 8: 52,6^{\circ} \mathrm{C} ; 9: 52,8^{\circ} \mathrm{C}$ e $10: 53^{\circ} \mathrm{C}$ 
Os cães $2,3,4,5,6,7,8,9,10,11,12,13,14$ e 15 expressaram o gene LRP, previamente à quimioterapia, correspondendo à presença de banda na posição 280 bp (Figura 4.11). A freqüência de expressão para o gene LRP encontrada nesses animais, ao diagnóstico foi 93,3\% (14/15), atingindo 100\% (15/15) durante a recidiva, na qual, o cão 1 tornou-se positivo para o LRP, conforme tabela 4.1.

Portanto, a freqüência de expressão intrínseca foi de 93,3\% (14/15) e a de expressão adquirida de $6,7 \%$ (1/15), como indicado na tabela 4.1 .

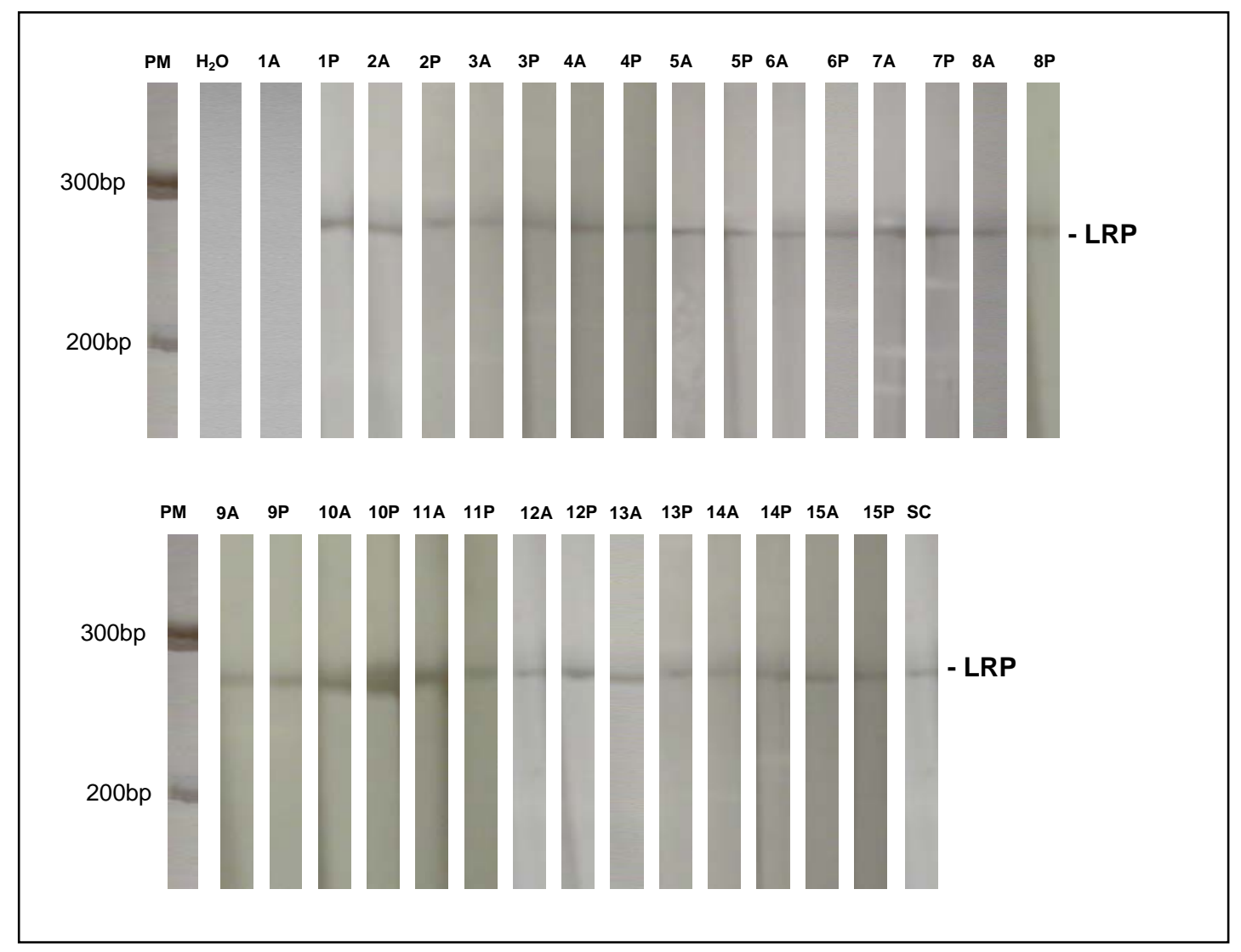

Figura 4.11 - Eletroforese em gel de poliacrilamida a 6\% corado com prata da reação de RT-PCR para detecção do gene LRP em cães com linfoma multicêntrico. PM: padrão de peso molecular de 100bp; A: previamente a quimioterapia; P: recidiva do linfoma 


\subsubsection{Expressão da LRP por "Dot Blot"}

Foi realizada curva de titulação do anticorpo primário para se atingir uma titulação ideal. O título ideal para o anticorpo anti-LRP foi 2000 conforme mostra a figura 4.12. Células de sarcoma uterino humano resistentes à doxorrubicina foram utilizadas como controle positivo da reação.

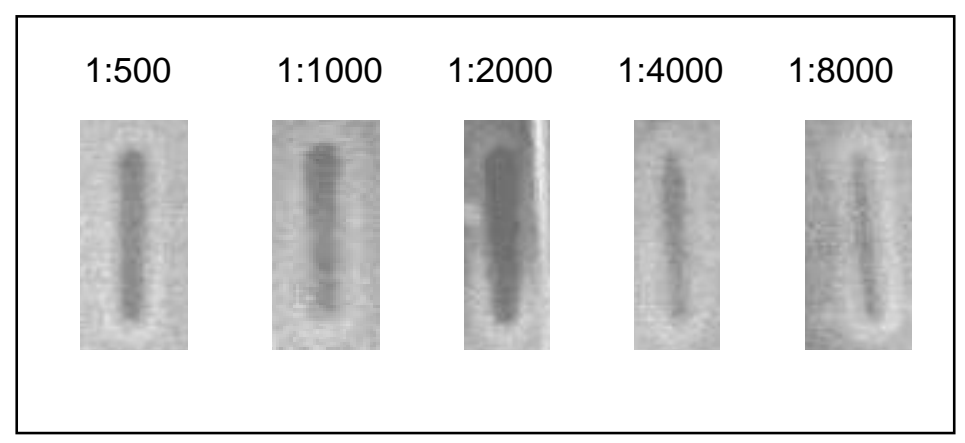

Figura 4.12 - Titulação do anticorpo primário anti-LRP

Os cães 2, 3, 4, 5, 7, 8, 10, 11, 12, 13, 14 e 15 expressaram a proteína LRP ao diagnóstico, representando uma freqüência de 85,8\% (12/14) de positividade para esta proteína (Figura 4.13), conforme tabela 4.1. Os cães 6 e 9, inicialmente negativos para esta proteína, passaram a expressá-la durante a recidiva, elevando a freqüência da LRP para 100\% (14/14).

Portanto, a freqüência de expressão intrínseca foi 85,8\% (12/14) e a de expressão adquirida 14,2\% (2/14), como indicado pela tabela 4.1. 


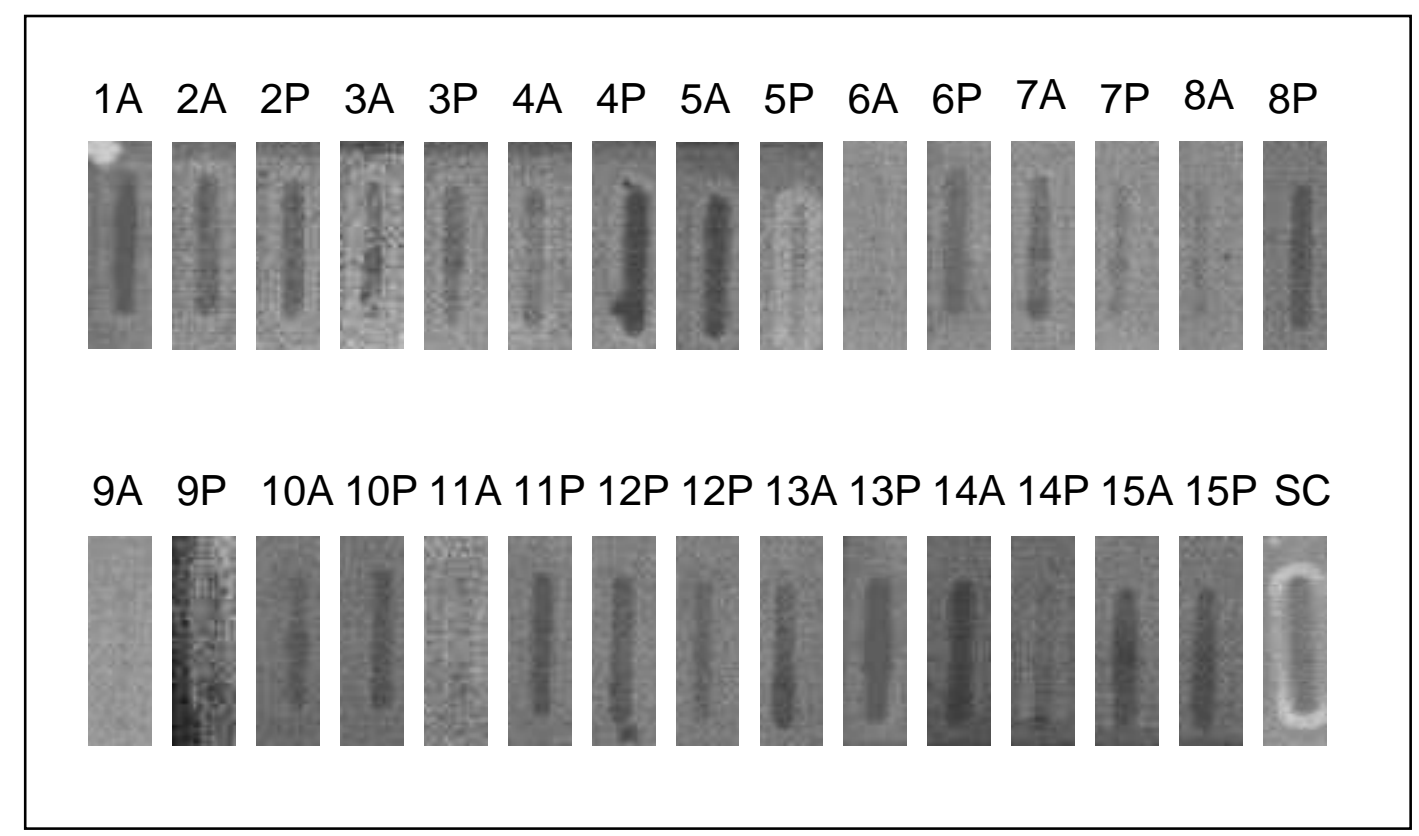

Figura 4.13 - "Slot Dot" anti-LRP em membrana de PVDF de cães com linfoma multicêntrico. A: previamente a quimioterapia; P: recidiva do linfoma; SC: sarcoma uterino resistente à doxorrubicina

\subsubsection{Estudo da Expressão do Gene $\beta_{2}$-microglobulina Canina}

\subsubsection{RT-PCR}

A expressão do gene da $\beta_{2}$-microglobulina canina foi utilizada como controle interno de amplificação. Foi necessário adequar as condições de RT-PCR para verificar a expressão deste gene. A figura 4.14 mostra o gel de agarose a $2 \%$, da curva construída para análise da temperatura de anelamento ótima. A temperatura de anelamento $62,7^{\circ} \mathrm{C}$ foi considerada como a melhor para esta reação. 


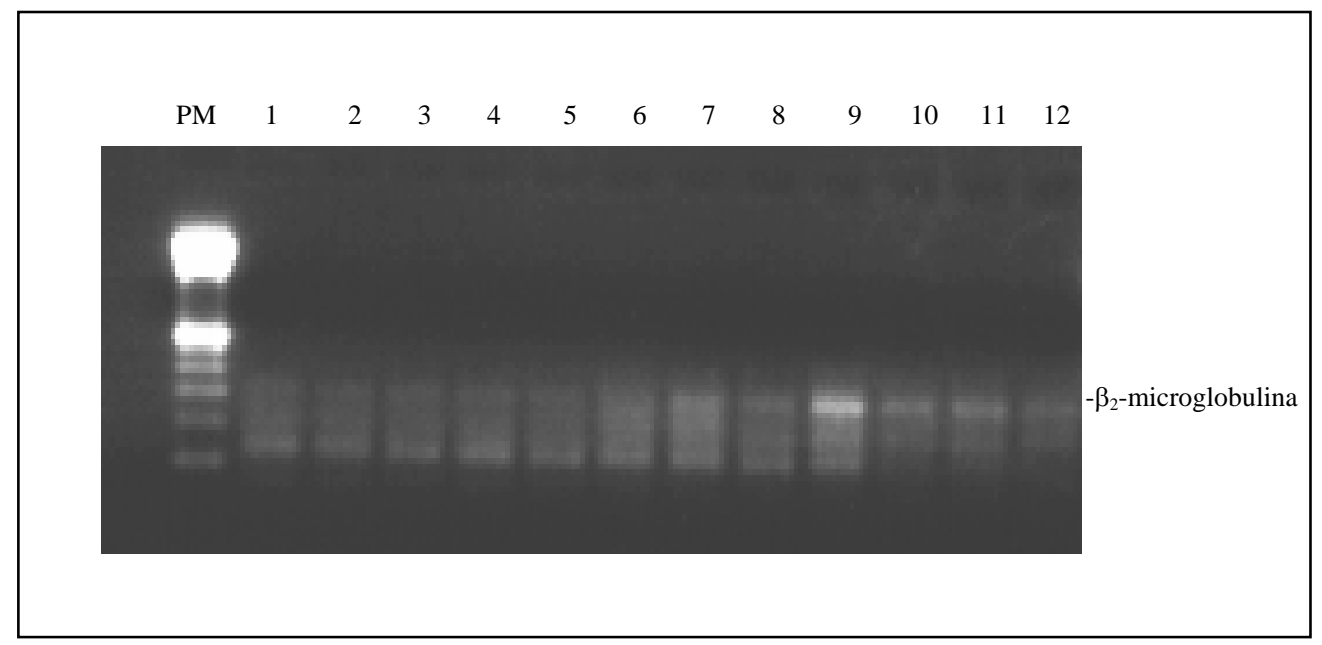

Figura 4.14 - Curva de temperaturas de anelamento para reação de RT-PCR de DOG $\beta_{2}$-microglobulina em gel de agarose $2 \%$ corado com brometo de etídio(PM: padrão de peso molecular; 1: $50^{\circ} \mathrm{C}$; 2: $50,4^{\circ} \mathrm{C}$; 3 : $51,2^{\circ} \mathrm{C}$; 4: $52,5^{\circ} \mathrm{C}$; : $54,2^{\circ} \mathrm{C} ; 6: 56,4^{\circ} \mathrm{C} ; 7: 58,9^{\circ} \mathrm{C} ; 8: 51^{\circ} \mathrm{C} ; \mathbf{9}$ : $62,7^{\circ} \mathrm{C} ; 10: 63,9^{\circ} \mathrm{C} ; 11: 64,7^{\circ} \mathrm{C} ; 12: 65^{\circ} \mathrm{C}$ ) em cão com linfoma multicêntrico

Conforme pode ser notado na figura 4.15, todos os cães expressaram a banda correspondente ao produto de amplificação da $\beta_{2}$-microglobulina canina. Isto indica que todos os RNAs amostrais estavam em boas condições para serem amplificados. 


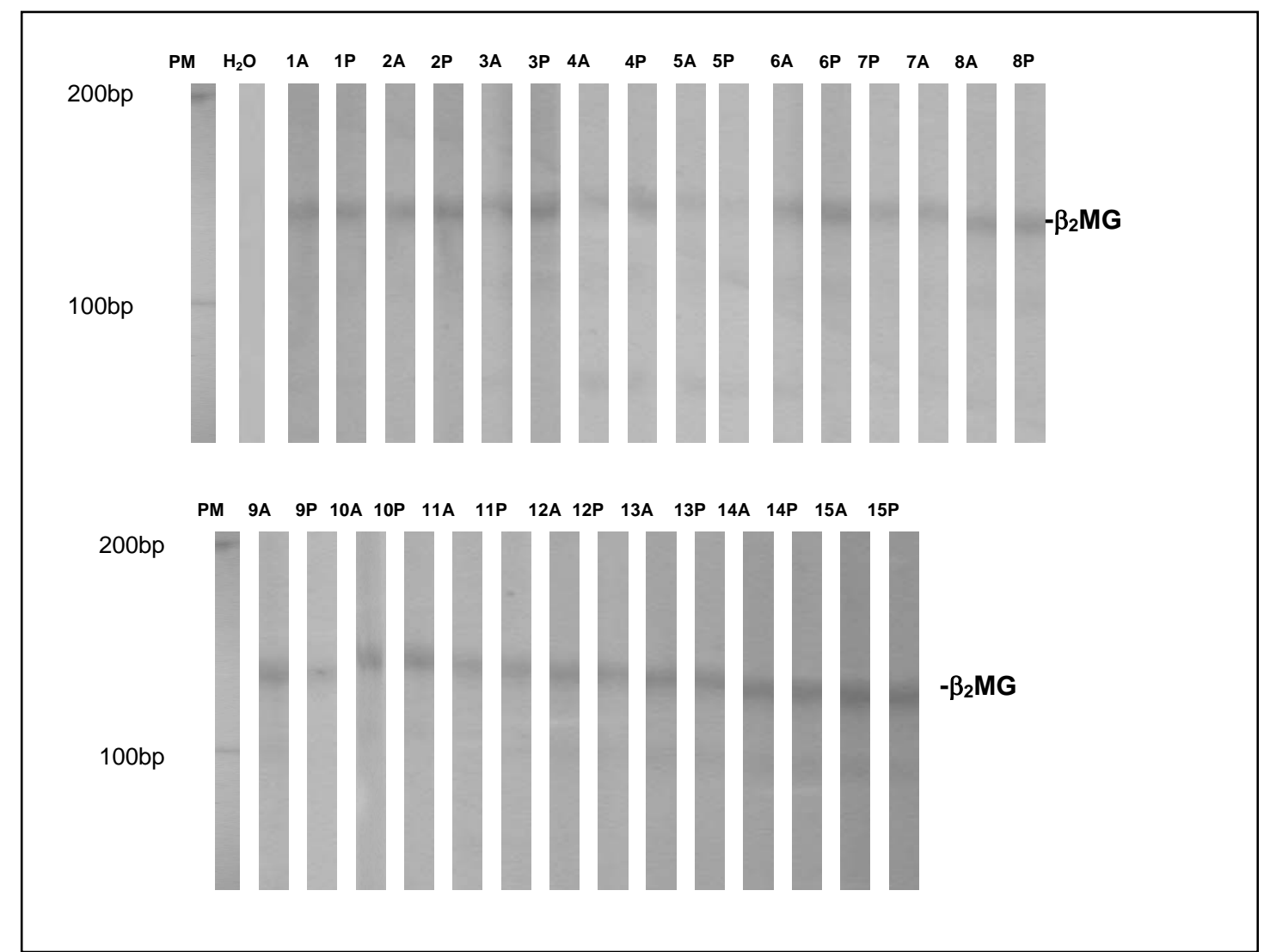

Figura 4.15 - Eletroforese em gel de poliacrilamida a $6 \%$ corado com prata da reação de RTPCR para detecção do gene DOG $\beta_{2}$-microglobulina em cães com linfoma multicêntrico. PM: padrão de peso molecular de 100bp; A: previamente a quimioterapia; P: recidiva do linfoma

\subsubsection{Apresentação das Freqüências}

O quadro 4.3 indica a expressão de cada gene ou proteína por cada amostra isoladamente. Observa-se que em quase todos os animais houve a co-expressão dos genes e proteínas de resistência estudados, exceto nas amostras identificadas como 1A, 6A, 7A, 7P, 9A, 9P e 11A. 


\begin{tabular}{|c|c|c|c|c|c|c|}
\hline ID & MDR-1 & P-gp & MRP-G & MRP-P & LRP-G & LRP-P \\
\hline $1 \mathrm{~A}$ & + & $*$ & + & $*$ & - & ( \\
\hline $1 \mathrm{P}$ & + & + & + & + & + & + \\
\hline $2 \mathrm{~A}$ & + & + & + & + & + & + \\
\hline $2 \mathrm{P}$ & + & + & + & + & + & + \\
\hline $3 \mathrm{~A}$ & + & + & + & + & + & + \\
\hline $3 \mathrm{P}$ & + & + & + & + & + & + \\
\hline $4 \mathrm{~A}$ & + & + & + & + & + & + \\
\hline $4 \mathrm{P}$ & + & + & + & + & + & + \\
\hline $5 \mathrm{~A}$ & + & + & + & + & + & + \\
\hline $5 \mathrm{P}$ & + & + & + & + & + & + \\
\hline $6 \mathrm{~A}$ & + & - & + & - & + & - \\
\hline $6 \mathrm{P}$ & + & + & + & + & + & + \\
\hline $7 \mathrm{~A}$ & + & + & + & - & + & + \\
\hline $7 \mathrm{P}$ & + & + & + & - & + & + \\
\hline $8 \mathrm{~A}$ & + & + & + & + & + & + \\
\hline $8 \mathrm{P}$ & + & + & + & + & + & + \\
\hline $9 \mathrm{~A}$ & - & - & - & - & + & - \\
\hline $9 \mathrm{P}$ & + & - & + & + & + & + \\
\hline $10 \mathrm{~A}$ & + & + & + & + & + & + \\
\hline $10 \mathrm{P}$ & + & + & + & + & + & + \\
\hline $11 \mathrm{~A}$ & + & + & + & - & + & + \\
\hline $11 \mathrm{P}$ & + & + & + & + & + & + \\
\hline $12 \mathrm{~A}$ & + & + & + & + & + & + \\
\hline $12 \mathrm{P}$ & + & + & + & + & + & + \\
\hline $13 \mathrm{~A}$ & + & + & + & + & + & + \\
\hline $13 \mathrm{P}$ & + & + & + & + & + & + \\
\hline $14 \mathrm{~A}$ & + & + & + & + & + & + \\
\hline $14 \mathrm{P}$ & + & + & + & + & + & + \\
\hline $15 \mathrm{~A}$ & + & + & + & + & + & + \\
\hline $15 \mathrm{P}$ & + & + & + & + & + & + \\
\hline & + & + & + & + & & \\
\hline & + & + & + & + & + & + \\
\hline
\end{tabular}

Legenda : A - ao diagnóstico, $\mathrm{P}$ - na recidiva, * material não pôde ser colhido

Quadro 4.4 - Distribuição das amostras de 15 cães com linfoma multicêntrico, segundo positividade ou negatividade para o gene MDR-1, P-gp, gene MRP (MRP-G), proteína MRP (MRPP), gene LRP (LRP-G) e proteína LRP (LRP-P).Laboratório de Hematologia Molecular, LIM-31, FMUSP , São Paulo - março/03 a setembro/04

A tabela 4.1 aponta as freqüências de expressão dos genes e proteínas de resistência ao diagnóstico, na recidiva tumoral e a expressão adquirida, ou seja, aquela obtida entre as fases do diagnóstico e da recidiva tumoral. 
Tabela 4.1 - Distribuição da freqüências de expressão para o gene MDR-1, P-gp, gene MRP, proteína MRP, gene LRP e proteína LRP, ao diagnóstico, na recidiva e a adquirida, em 15 cães com linfoma multicêntrico. Laboratório de Hematologia Molecular, LIM-31, FMUSP , São Paulo - março/03 a setembro/04

\begin{tabular}{cccc}
\hline EXPRESSÃO & DIAGNÓSTICO (\%) & RECIDIVA (\%) & ADQUIRIDA(\%) \\
MDR-1 & $93,3(14 / 15)$ & $100(15 / 15)$ & $6,7(1 / 15)$ \\
P-gp & $85,8(12 / 14)$ & $92,9(13 / 14)$ & $7,1(1 / 14)$ \\
MRP-GENE & $93,3(14 / 15)$ & $100(15 / 15)$ & $6,7(1 / 15)$ \\
MRP-PROT & $71,5(10 / 14)$ & $92,9(13 / 14)$ & $21,4(3 / 14)$ \\
LRP-GENE & $93,3(14 / 15)$ & $100(15 / 15)$ & $6,7(1 / 15)$ \\
LRP-PROT & $85,8(12 / 14)$ & $100(14 / 14)$ & $14,2(2 / 14)$ \\
\hline
\end{tabular}




\section{DISCUSSÃO}

Dentre os animais em estudo, o Linfoma Linfoblástico foi o predominante, representando 60\% (9/15), seguido pelo Linfoma Linfocítico de Pequenas Células 26,6\% (4/15), Difuso Misto de Grandes e Pequenas Células 6,7\% (1/15) e pelo Difuso de Grandes Células 6,7\% (1/15). Apresentaram ainda, um estadiamento clínico inicial avançado, compreendendo os estágios III, IV ou V, caracterizados pelo envolvimento de linfonodos, fígado, baço e até possivelmente a medula óssea.

Dentre os 15 animais analisados, 10 apresentaram remissão completa e 5 remissão parcial, com a terapia citotóxica de indução, o que concorda com os dados observados por Fan (2003), Rosenthal (1990), Withrow e MacEwen (2001). Tanto naqueles casos tratados com o protocolo $\mathrm{COP}$, quanto naqueles submetidos ao VCM, 66,7\% dos cães apresentaram remissão completa e 33.3\% remissão parcial.

As médias de duração da remissão e de sobrevida destes cães foram menores do que as médias relatadas por Ettinger (2003), Fan (2003), Withrow e MacEwen, (2001). Uma das possíveis explicações para este fato, pode ser o atendimento tardio dos cães com linfoma. Em nosso meio, a maioria dos proprietários não observa pequenas alterações nas dimensões dos linfonodos, não associam sintomas inespecíficos como êmese e diarréia, a doenças neoplásicas, colaborando para a evolução da doença e reduzindo as chances iniciais de boa resposta ao tratamento.

A maioria dos animais apresenta remissão completa após a fase inicial da quimioterapia, entretanto, mesmo com uma boa resposta ao tratamento, as recidivas são freqüentes durante o período de manutenção da remissão (ETTINGER, 2003; 
ROSENTHAL,1990; WITHROW, MACEWEN, 2001), fato também observado nos casos aqui estudados.

Poucos agentes são capazes de levar a uma segunda remissão e as chances de uma resposta satisfatória caem para aproximadamente 40\% (WITHROW; MACEWEN, 2001).Assim, a quimioterapia com drogas diferentes daquelas utilizadas inicialmente não produz mais resposta e este fato pode estar relacionado ao fênomeno MDR, a exemplo do que ocorre em seres humanos com linfoma nãoHodgkin durante a recidiva (MOORE et al., 1995).

Sabe-se que drogas como a vincristina e a prednisona, utilizadas no tratamento dos animais deste estudo, são capazes de induzir os mecanismos genéticos de resistência, durante o decorrer do tratamento quimioterápico (BERGMAN; OGILVIE; POWERS, 1996; FAN, 2003).

Nos casos incluídos nesta pesquisa, detectou-se a expressão do gene MDR-1 em 93,3\% (14/15) e a P-gp em 85,8\% (12/14) dos cães com linfoma multicêntrico ao diagnóstico. Na recidiva tumoral, a expressão do MDR-1 chegou a 100\% (15/15) e a P-gp a 92,9\% (13/14), nos mesmos animais.

Moore et al. (1995) relataram a presença da P-gp em linfonodos periféricos, em 3\% (1/30) de cães com linfoma multicêntrico ao diagnóstico e em 40\% (3/8) dos mesmos, durante a recidiva, por meio da técnica de "Western Blotting".

Lee et al. (1996) estudaram a expressão da P-gp em 15 cães com linfoma, por imuno-histoquímica, utilizando os anticorpos C494 e C219, anti-P-gp, em material colhido de linfonodos periféricos. Ao se utilizar o anticorpo C494, obteve-se em 75\% dos cães a expressão da P-gp menor do que 10\%, e em $25 \%$ dos mesmos, a P-gp foi maior ou igual à 10\%. Nessas mesmas condições, com o anticorpo C219, 73\% dos casos apresentaram expressão da P-gp menor do que 10\% e em 27\% a 
expressão da P-gp foi maior ou igual a 10\%. Independentemente do nível de expressão encontrada, notou-se uma alta positividade de P-gp ao diagnóstico.

$\mathrm{Na}$ recidiva do linfoma, estes valores elevaram-se consideravelmente. Ao utilizar o C494 e C219, em apenas 17\% e 27\% dos casos, a expressão da P-gp foi menor do que $10 \%$ e em $83 \%$ e $73 \%$ a expressão da P-gp foi maior ou igual a 10\%, respectivamente (LEE et al., 1996). Assim, um aumento significativo da expressão da P-gp na recidiva tumoral em relação ao diagnóstico, sugeriu a esses autores que o mecanismo P-gp poderia estar envolvido no insucesso do tratamento e constituir um fator prognóstico negativo em relação à recidiva do linfoma canino.

No mesmo ano, Ginn detectou a expressão da P-gp em 27\% (6/22) de cães com linfoma mullticêntrico, por imuno-histoquímica, também utilizando o anticorpo C494, em amostras de linfonodos periféricos. Infelizmente, este autor não revelou em que momento a amostra foi obtida, dificultando a execução de uma análise comparativa.

Ainda em 1996, Bergman, Ogilvie e Powers avaliaram a expressão da P-gp por imuno-histoquímica, com anticorpo C219, em cães com linfoma ao diagnóstico, recidiva e na necrópsia, a partir de material colhido de linfonodos periféricos. Notaram um aumento progressivo da frequência de células positivas ao C219 do diagnóstico até a recidiva e necrópsia. Observaram ainda, que quanto maior fosse o número de tratamentos de resgate instituídos, havia uma maior quantidade de P-gp expressa por essas células. Assim, para esses autores, a P-gp pareceu estar relacionada a ausência de resposta ao tratamento do linfoma canino. Além disso, concluíram que a expressão da P-gp pode ter valor preditivo quanto aos tempos de remissão e de sobrevida em cães com linfoma multicêntrico, uma vez que esses 
foram menores em cães com alta expressão de P-gp (BERGMAN; OGILVIE; POWERS, 1996).

Steingold et al. (1998) encontraram uma elevada expressão do gene MDR-1, por RT-PCR, em apenas 18\% (2/11) de cães com linfoma submetidos ao tratamento citotóxico, apesar de observar a expressão deste gene em todos os casos.

Contrariamente aos relatos anteriores, estes pesquisadores não observaram nenhuma relação entre a expressão do gene MDR-1 e resposta ao tratamento, apesar do estudo anterior da mesma equipe ter relatado o oposto (STEINGOLD et al.,1998).

Existem muitas explicações para a ausência de associação entre a expressão do gene MDR-1, atividade da P-gp e resposta clínica. Dentre estas, pode-se citar a possível existência de outros mecanismos de resistência a múltiplas drogas mais relevantes para a resposta clínica ou ainda, o fato de que a regulação do gene MDR1 possa ocorrer após a transcrição do RNA mensageiro. Além disso, nada poderia ser afirmado quanto à atividade da P-gp, essencial para o desenvolvimento do fenótipo MDR (STEINGOLD et al.,1998).

Recentemente, Culmsee et al. (2004) quantificaram a expressão do gene MDR-1, por RT-PCR em tempo real, em amostras de linfonodos de cães saudáveis, com linfoma ou com outras afecções, não tratados. Todas as amostras expressaram algum nível de MDR-1, sendo que na maioria das vezes esse nível foi baixo. Não se estudou a expressão do MDR-1 durante a recidiva do linfoma. Dentre as formas anatômicas do linfoma canino analisadas, a alimentar expressou níveis mais elevados de MDR-1 do que a multicêntrica.

É interessante notar que a expressão do gene MDR-1 foi detectada em linfonodo normal (CULMSEE et al., 2004), fato não relatado em seres humanos. 
Possivelmente, esta expressão se mantenha em uma transformação neoplásica, podendo levar ao fenótipo de resistência a drogas até mesmo em cães não tratados, elevando a freqüência de resistência intrínseca no linfoma canino. Se considerarmos as observações de Ginn (1996) quanto à expressão do mecanismo MDR-1/P-gp em outras neoplasias caninas, como adenocarcinoma e adenoma de mama, carcinoma de células escamosas, melanoma, hemangiopericitoma, hepatoma, carcinoma das células de transição da bexiga, adenoma de adrenal, carcinoma de tireóide e adenoma ou adenocarcinoma colorretal, órgãos que expressam a P-gp fisiologicamente e que apresentaram uma expressão de $100 \%$ em estado neoplásico, o mesmo poderia então ser associado ao linfoma canino. Para confirmar esta hipótese, seria necessário realizar um estudo quantitativo e seriado da expressão do gene MDR-1, em cães com linfoma ao diagnóstico e na recidiva.

Assim como observado na Medicina Veterinária e em seres humanos, a freqüência de expressão do mecanismo MDR-1/P-gp varia bastante segundo os diversos estudos de literatura, tanto em casos de linfoma não-Hodgkin quanto em outras neoplasias (BECKER; HOSSFELD, 1996; NIEHANS et al., 1992).

Em relação à expressão do MDR-1/P-gp em seres humanos, Yamaguchi et al. (1995) por RT-PCR e imuno-histoquímica respectivamente, avaliaram 10 pacientes com linfoma nasal de células T, sendo 9 antes da quimioterapia. Nove dentre dez (90\%) dos pacientes foram positivos para P-gp e 7 dentre esses 9 (78\%) expressaram o gene MDR-1, indicando uma alta freqüência deste mecanismo ao diagnóstico.

Sabe-se que o linfoma nasal de células T não responde bem à quimioterapia convencional, incluindo drogas mediadas pelo MDR-1. Pacientes que receberam quimioterapia isoladamente apresentaram menor sobrevida. Assim, o mau 
prognóstico para pacientes com linfoma nasal tratados com quimioterapia, poderia ser explicado pela expressão intrínseca do MDR-1/P-gp (Yamaguchi et al., 1995).

Jillella et al. (2000) avaliaram a expressão da P-gp por imuno-histoquímica em 25 pacientes com linfoma cutâneo de células T. Dentre os 25 pacientes, $72 \%(18 / 25)$ expressaram a P-gp, sendo 9 tratados com drogas quimioterápicas mediadas pela P-gp e 9 sem tratamento citotóxico. Notou-se neste estudo que tanto pacientes positivos quanto negativos para P-gp não responderam à quimioterapia e morreram pela progressão da doença. Assim, a alta freqüência da P-gp observada neste tumor não constituiu um fator preditivo. Nesse caso, outros mecanismos de resistência poderiam estar envolvidos ou até pelo fato do linfoma cutâneo de células T apresentar baixa resposta ao tratamento, com mau prognóstico.

Em relação a outras neoplasias hematopoiéticas humanas, as freqüências do MDR-1/P-gp também variam bastante. Nos diferentes casos de leucemias, a freqüência do MDR-1/P-gp ao diagnóstico é de 15-70\% e na recidiva de 30-100\%; no mieloma múltiplo esta freqüência ao diagnóstico é de 6-25\% e na recidiva de 30100\%; no linfoma não-Hodgkin humano, a freqüência encontrada ao diagnóstico é de 0-67\% e na recidiva de 0-71\% (BECKER; HOSSFELD, 1996; GOTTESMAN; FOJO; BATES, 2002; LEONARD; FOJO; BATES, 2003). Essa grande variação encontrada em relação às freqüências do MDR-1/P-gp tem como possíveis explicações os diferentes métodos empregados para avaliar a expressão do MDR1/P-gp, falta de consenso literário quanto à adoção de um ponto "cut off" padrão. Além disso, a maioria dos trabalhos de pesquisa para o MDR-1/P-gp, não faz uma análise seriada com a finalidade de estudar mudanças na expressão dos mesmos pacientes. Na maioria das vezes, ocorre entre diferentes pacientes e em momentos distintos (BECKER; HOSSFELD, 1996; NIEHANS et al., 1992). 
Niehans et al. (1992) estudaram a expressão da P-gp por imuno-histoquímica, em 57 pacientes com linfoma imunoblástico ou difuso de grandes células, previamente à quimioterapia. Notaram que 49\% (28/57) dos casos expressaram a Pgp, 25\% (14/57) possivelmente expressaram a P-gp, devido à presença de baixa imunorreatividade e 26\% (15/17) foram negativos para a P-gp.

A expressão intrínseca da P-gp foi relatada em 50-100\% dos casos de leucemia linfocítica crônica (PERRI; LOUIE; ESPAR, 1989), 40\% das leucemias de células T e linfomas (KUWAZURU et al., 1990), 30\% dos mielomas (EPSTEIN; XIAO; OBA, 1989), em seres humanos.

Goldstein et al. (1989) relataram a expressão do MDR-1 em 22\% dos pacientes com linfoma não tratados; enquanto Moscow et al. (1989) encontraram a expressão do gene MDR-1 em 36\%, nestas mesmas condições. Por outro lado, Poje et al. (1991) identificaram apenas 3\% (3/100) de positividade para a P-gp em linfomas, de forma intrínseca.

No caso do linfoma não-Hodgkin canino ou humano, alguns autores relataram uma baixa freqüência do MDR-1/P-gp ao diagnóstico, seguida por um aumento na expressão deste mecanismo durante a recidiva, induzido pelo tratamento quimioterápico (LIU; OHSHIMA; KIKUCHI, 2001). Por outro lado, outros pesquisadores encontraram uma alta expressividade do MDR-1/Pgp não só na recidiva, mas ao diagnóstico (LIU; OHSHIMA; KIKUCHI, 2001; NIEHANS et al., 1992).

Esperava-se que a alta expressão do mecanismo MDR-1/P-gp previamente à quimioterapia observada no presente estudo, e como havia sido observado por Niehans et al. (1992), estivesse correlacionada a uma baixa resposta à terapia de 
indução, a exemplo do que ocorre em neuroblastomas e mielomas, em seres humanos (NIEHANS et al., 1992).

Contrariamente às expectativas iniciais de Moscow et al. (1989) e Niehans et al. (1992), a expressão intrínseca do mecanismo MDR-1/P-gp, detectada no presente estudo, não reduziu a resposta à terapia de indução. Dentre os 15 cães estudados, observou-se em $66,7 \%$ remissão completa e em 33,3\% remissão parcial. Conforme Niehans et al. (1992) em casos de linfoma não-Hodgkin, mesmo com uma taxa de resistência intrínseca alta de 70\%, 6 dentre os 10 casos estudados, obtiveram remissão completa, 2 apresentaram remissão parcial e 2 não responderam. Desta forma, houve resposta à terapia de indução mesmo com a expressão da P-gp.

Uma das possíveis hipóteses para explicar esse paradoxo está no fato de que as técnicas utilizadas nos estudos em questão, não foram quantitativas. Não se sabe de forma quantitativa, a expressão do gene MDR-1 ou da P-gp presentes em cada amostra, apenas se estão presentes ou não.

Não existe concordância entre os diversos trabalhos quanto às concentrações de MDR-1 que determinem o fenótipo MDR. Alguns estudos consideram qualquer nível de expressão de MDR-1 capaz de levar ao fenômeno MDR, enquanto outros afirmam a necessidade de determinados níveis de expressão para sua manifestação (BECKER; HOSSFELD, 1996).

Assim, parece ser necessária uma determinada expressão de MDR-1/P-gp, a partir da qual, desencadeia-se o fenômeno de resistência a múltiplas drogas. Em termos moleculares, esta hipótese pode ser mais facilmente compreendida.

Cada molécula de P-gp é conceituada como uma bomba dependente de energia, capaz de levar à extrusão de certo número de moléculas de substâncias 
tóxicas por minuto. Desta forma, a sobrevida da célula dependerá de quantidade suficiente de moléculas de P-gp para remover as moléculas presentes, antes que uma citotoxicidade irreversível ocorra. Assim, a administração de altas doses de drogas citotóxicas pode sobrecarregar as moléculas de P-gp, em células com baixa expressão de P-gp (NIEHANS et al., 1992).

Este tipo de situação pode ter ocorrido no presente estudo, ou seja, as células poderiam apresentar uma baixa expressão de P-gp ao diagnóstico e seriam incapazes de reverter a citotoxicidade promovida pelos quimioterápicos, levando a uma boa resposta à terapia de indução.

Outras possíveis explicações poderiam estar relacionadas à atividade da proteína P-gp. Detectou-se apenas a presença ou não do MDR-1/Pgp e não foi possível avaliar se a P-gp quando presente estava ativa ou não. Uma das possíveis técnicas existentes para se analisar o funcionamento da P-gp seria por meio da técnica de Rodamina 123, conforme Webb et al. (1996). Para isso, existe a necessidade de cultura celular e toda padronização prévia para o linfoma canino.

Além da alta freqüência de expressão do MDR-1/P-gp, foram encontrados 4 cães que possivelmente, apresentaram polimorfismos referentes ao gene MDR-1. Os polimorfismos do gene MDR-1 podem levar a uma variabilidade genética da $\mathrm{P}$ gp, interferindo na distribuição celular de drogas e por conseqüência na eficácia do tratamento (LEONARD; FOJO; BATES, 2003).

Os polimorfismos do MDR-1/P-gp já foram descritos em certos camundongos e em alguns cães da raça collie, que apresentam mutação por deleção espontânea no gene MDR-1. Nessas espécies, essa mutação pode resultar na perda completa da função transportadora da P-gp (LEONARD; FOJO; BATES, 2003; MEALEY; NORTHRUP; BENTJEN, 2003; NEFF et al., 2004; ROULET et al., 2003). 
Em seres humanos já foram relatados vários tipos de polimorfismos no gene MDR-1. Dentre esses, pode-se citar a mutação C3435T que ocasiona uma redução na expressão da P-gp, elevando a biodisponibilidade dos substratos de P-gp o que pode afetar sobremaneira a eficácia do tratamento (LEONARD; FOJO; BATES, 2003; MARZOLINI et al., 2004). Existem ainda estudos que indicaram a associação entre os polimorfismos do gene MDR-1 e a ocorrência de doenças como a colite ulcerativa, carcinoma renal e AIDS, em seres humanos (MARZOLINI et al., 2004).

Neste estudo, encontraram-se também, altas freqüências de expressão para o gene e proteína MRP. A expressão do gene e da proteína MRP foram observados em 93,3\% (14/15) e 71,5\% (10/14) dos pacientes ao diagnóstico e em 100\% (15/15) e 92,9\% (13/14) na recidiva, respectivamente.

Miyoshi et al. (2002) avaliaram 54 amostras teciduais de mastocitoma canino ao diagnóstico, por imuno-histoquímica, para a detecção de P-gp e MRP. A expressão da P-gp foi observada em 15\% (8/54) e a MRP em 18\% (10/54) dos casos. Em Medicina Veterinária, apenas este trabalho relatou a expressão da MRP. Não existe um estudo relacionado ao linfoma canino.

Em seres humanos, a expressão da MRP-1 nas leucemias está em torno de 10\% ao diagnóstico e 34\% na recidiva, em câncer de pulmão de $80-100 \%$, em tumores de bexiga de baixo grau de $75 \%$ ao diagnóstico e de $80 \%$ na recidiva e em câncer uterino de 40-88\% ao diagnóstico e 83-88\% na recidiva (GOTTESMAN; FOJO; BATES, 2002; LEONARD; FOJO; BATES, 2003).

Zhan et al. (1997) analisaram a expressão do gene e da proteína MRP-1, por PCR quantitativa e "immunoblotting" respectivamente, em 40 pacientes com linfoma. Desses 40 pacientes, 15 foram utilizados para avaliação da expressão da MRP ao diagnóstico e na recidiva. 
Não houve diferença significativa quanto à expressão do gene MRP ao diagnóstico e em relação à fase de tratamento. Dois dentre os 15 pacientes expressaram a MRP em tratamento, com aumento de 10 a 18 vezes o valor obtido no diagnóstico (ZHAN et al., 1997).

Segundo Zhan et al. (1997), a MRP não constituiu o mecanismo responsável pelo fenótipo MDR nesses pacientes. Contrariamente ao MDR-1, a expressão do MRP RNAm é freqüente em muitas linhagens celulares, que não desenvolvem o fenótipo MDR (GOTTESMAN; FOJO; BATES, 2002; LEONARD; FOJO; BATES, 2003; ZHAN et al., 1997).

Estudos indicaram que a presença da MRP-1 em células de carcinoma de ovário humano sensíveis à doxorrubicina é responsável por uma baixa freqüência de resistência intrínseca, freqüentemente observada em casos clínicos não tratados (MORAN et al., 1997).

Utilizando a técnica de imuno-histoquímica, Filipts et al. (2000), avaliaram a expressão da MRP-1 em 48 casos de linfoma difuso de células B, não tratados. A expressão da MRP-1 foi observada em 44\% (21/48) dos casos, ao diagnóstico.

Não houve diferença significativa quanto ao tipo de remissão e sobrevida entre os pacientes que expressaram ou não a MRP-1, indicando que talvez não ocorra a participação desta proteína no fenótipo de resistência (FILIPTS et al., 2000).

A alta freqüência de expressão intrínseca do gene e da proteína MRP pode estar associada ao fato de que esta proteína está presente na maioria dos tecidos, podendo conferir resistência ou não. Não foi possível verificar se o fenótipo MDR foi induzido ou não pelo MRP, como referido por Borst et al. (2000).

Sabe-se que ele está presente, mas é preciso analisar se este mecanismo está atuando no efluxo de drogas ou não. Para isso, seria preciso estudar a 
atividade da proteína MRP isoladamente, pela inibição dos outros mecanismos MDR. Nem mesmo em casos humanos, comprovou-se a participação da MRP na indução de resistência a múltiplas drogas .

O último mecanismo estudado foi aquele representado pelo gene e proteína LRP. A expressão do gene e da proteína LRP foi observada em 93,3\% (14/15) e 85,8\% (12/14) dos casos ao diagnóstico e em 100\% (15/15) e 100\% (14/14) na recidiva respectivamente em nosso estudo.

Não existe publicação a respeito da presença das "Vaults" tanto em tecido normal quanto neoplásico em Medicina Veterinária. Na Medicina, existem relativamente poucos estudos sobre a expressão da LRP em linfoma não-Hodgkin, quando comparados à expressão das proteínas ABC.

Segundo Mossink et al. (2003), a expressão da LRP na leucemia mielóide aguda em humanos é de 26-91\% ao diagnóstico, na leucemia linfoblástica aguda é de $10-47 \%$ ao diagnóstico, elevando-se para $68 \%$ na recidiva e no mieloma múltiplo de 47-74\% no diagnóstico. Em câncer de ovário em estágio avançado, 77\% dos pacientes expressaram LRP ao diagnóstico e em tumor de mama esta freqüência é de $69-75 \%$ tanto no diagnóstico quanto na recidiva. O mecanismo LRP parece desempenhar um importante papel no fenômeno de resistência em neoplasias hematopoiéticas.

Filipits et al. (2000) estudaram a expressão da proteína MRP-1 e LRP em 48 casos de linfoma difuso de grandes células B, não tratados. A expressão da LRP foi observada em apenas 23\% (11/48) dos casos, enquanto a MRP-1 em 44\% (21/48).

A expressão da LRP pôde ser notada com maior freqüência em pacientes com estágio da doença mais avançado e com baixa resposta ao tratamento 
citotóxico e menor sobrevida. Desta forma, a LRP pode constituir um importante mecanismo MDR nesta doença.

Outro estudo, porém "in vitro" também atesta para o envolvimento da LRP como um mecanismo de resistência a múltiplas drogas. Notou-se um aumento gradativo na expressão da LRP em células submetidas a crescentes concentrações de drogas citotóxicas, elevando o fenótipo de resistência dessas células. Além disso, a resistência observada foi independente de outros mecanismos, bloqueados no experimento realizado (HU et al., 2002).

Sauerbrey et al (2002) investigaram, por meio de RT-PCR semi-quantitativo, a possível expressão dos genes MRP-1 e LRP em crianças com leucemia linfoblástica aguda, sendo 58 ao diagnóstico e 28 na recidiva.

Em todos os casos analisados, houve a detecção dos genes MRP e LRP, em diferentes níveis, de forma heterogênea. Desta forma, os pacientes foram divididos em 2 grupos de alta ou baixa expressividade, utilizando-se um valor "cut off". Não houve diferença quanto à expressão dos genes LRP e MRP ao diagnóstico e em relação à recidiva (SAUERBREY et al., 2002).

Os níveis de expressão dos genes LRP e MRP detectados foram superiores aos do tecido normal. A alta freqüência de expressão da MRP-1 não foi relacionada a um menor tempo de remissão, enquanto a expressão da LRP pareceu estar relacionada a menor duração da remissão, mas não houve significância estatística (SAUERBREY et al., 2002).

Portanto, a alta freqüência de expressão intrínseca da LRP encontrada nos cães estudados, pode estar contribuindo para a manifestação de resistência a drogas. Assim, há necessidade de avaliar a atividade desta proteína nas células de linfoma canino para fazer qualquer tipo de associação. 
Este estudo detectou ainda, uma alta freqüência de co-expressão entre os mecanismos MDR, MRP e LRP em cães com linfoma multicêntrico. Moran et al. (1997) e Mossink et al. (2003) afirmam que as piores respostas ao tratamento e sobrevida são encontradas em pacientes que co-expressam estas proteínas, assim como pôde ser observado nos cães estudados, e melhor prognóstico em pacientes negativos para esta co-expressão (MOSSINK et al., 2003; SAUERBREY et al., 2002).

No entanto, é necessário avaliar se existe uma co-atividade de todas estas proteínas e se as mesmas estão contribuindo de fato para o desenvolvimento do fenótipo de resistência. Uma vez que os mecanismos estão presentes, é possível que estas proteínas possam atuar, reduzindo consideravelmente as chances de boa resposta ao tratamento. 


\section{CONCLUSÕES}

Os genes MDR-1, MRP, LRP e seus produtos foram detectados no Linfoma Canino Multicêntrico, tanto no diagnóstico quanto na recidiva.

Obteve-se uma alta freqüência de expressão destes genes e proteínas, não só na recidiva, como também ao diagnóstico. Interessantemente, houve uma alta freqüência de co-expressão entre MDR-1/P-gp, MRP e LRP nos cães com linfoma, o que pode ter influenciado sobremaneira a resposta ao tratamento citotóxico.

Observou-se ainda, a possível presença de polimorfismos no gene MDR-1 em 4 cães com linfoma, tanto ao diagnóstico quanto na recidiva. Os polimorfismos podem ter modificado a expressão do MDR-1 nesses animais, assim como descrito na espécie humana.

Portanto, os mecanismos MDR estão presentes e possivelmente podem levar a alterações na resposta ao tratamento. O emprego de um método quantitativo poderia corroborar essa hipótese. 


\section{REFERÊNCIAS}

AMBUDKAR, S. V.; KIMCHI-SARFATY, C.; SAUNA, Z. E.; GOTTESMAN, M. M. Pglycoprotein: from genomics to mechanism. Oncogene, v. 22, p. 7468-7485, 2003.

BATES, S. E. Drug resistance: still on the learning curve. Clinical Cancer Research, v. 5, p. 3346-3348, 1999.

BECKER, S. H.; HOSSFELD, D. K. The MDR phenotype in hematologic malignancies: prognostic relevance and future perspectives. Annais Hematolology, v. 72, p. 105-117, 1996.

BERGER, W.; HAUPTMANN, E.; ELBLING, L.; VETTERLEIN, M.; KOKOSCHKA, E. M.; MICKSCHE, M. Possible role of the multidrug resistance-associated protein (MRP) in chemorresistance of human melanoma cells. Internal Journal of Cancer, v. 71, p. 108-115, 1997.

BERGMAN, P. J. Mechanisms of anticancer drug resistance. Veteterinary Clininical Small Animal, v. 33, p. 651-667, 2003.

BERGMAN, P. J.; OGILVIE, G. K.; POWERS, B. E. Monoclonal antibody C219 immunohistochemistry against P-glycoprotein: sequential analysis and predictive ability in dogs with lymphoma. Journal of Veterinary Internal Medicine, v. 10, n. 06, p. 354-359, 1996.

BERGMEYER, H. U. Glutamate-oxaloacetate transaminase: Methods of enzimatic analysis. Verlag Chemie, v. 2, n. 7, p. 727-773, 1974.

BIRGEL, E. H.; BENESI, F. J. Patologia clínica veterinária. Sociedade Paulista de Medicina Veterinária, p. 2-34, 1982.

BORST, P.; EVERS, R.; KOOL, M.; WIJHHOLDS, J. A family of drug transporters: The multidrug resistance-associated proteins. Journal of The National Cancer Institute, v. 92, n. 16, p. 1295-1302, 2000.

CHENG, S. H.; LAM, W.; LEE, A. S. K.; FUNG, K. P.; WU, R. S. S.; FONG, W. F. Low-level doxorrubicin resistance in benzol[a] pyrene-treated KB-3-1 cells is associated with increased LRP expression and altered subcellular drug distribution. Toxicology and Apllied

Pharmacology, v. 164, p. 1341-1342, 2000. 
COLE, S. P.; BHARDWAJE, G.; GERLACH, J. H.; MACKIE, J. E.; GRANT, C. E.; ALMQUIST, K. C. Overexpression of a transporter gene in a multidrug-resistant human lung cancer cell line. Science, v. 258, p. 1650-1654, 1992.

CONRAD, S.; VIERTELHAUS, A.; ORZECHOWSKI, A.; HOOGSTRAATE, J.; GJELLAN, K.; SCHRENK, D.; KAUFFMANN, H. M. Sequencing and tissue distribution of the canine MRP2 gene compared with MRP1 and MDR1. Toxicology, v.156, p.81-91, 2001.

CROOP, J. M.; GROS, P.; HOUSMAN, D. E. Genetics of multidrug resistance. Journal of Clinical Investigation, v. 81, p. 1303-1309, 1988.

CULMSEE, K.; GRUBER, A. D.; VON SAMSON-HIMMELSTJERNA, G.; NOLTE, I. Quantification of MDR-1 gene expression in canine tissues by real-time reverse transcription quantitative polymerase chain reaction. Research in Veterinary Science, v. 77, p. 223-229, 2004.

DALTON, W. S.; CROWLEY, J. J.; SALMON, S. S.; GROGAN, T. M.; LAUFMAN, L. R.; WEISS, G. R.; BONNET, J. D. A phase III randomized study of oral verapamil as a chemosensitizer to reverse drug resistance in patients with refractory myeloma. Cancer, v. 75, n. 3, p. 815-820, 1995.

DANO, K. Active outward transport of danomycin in resistant Ehrlich ascites tumor cells. Biochemistry and Biophysics Acta, v. 323, p. 466-483, 1973.

DOBSON, J. M.; GORMAN, N. T. Canine multicentric lymphoma. Clinicopathological presentation of the disease. Journal Small Animal Practice, v. 34, p. 594-598, 1993.

DOUMAS, B. T. ; BIGGS, H. G.; WATSON, W. Albumin standards and the measurement of serum albumin with bromocresol green. Clinica Chemica Acta, v. 31, p. 87-96, 1971.

EPSTEIN, J.; XIAO, H.; OBA, B. K. P-glycoprotein expression in plasma-cell myeloma is associated with resistance to VAD. Blood, v. 74, p. 913-917, 1989.

ETTINGER, S. N. Principles of treatment for canine lymphoma. Clinical Techniques in Small Animal Practice, v. 18, n. 2, p. 92-97, 2003.

FAN, T. M. Lymphoma updates. Veterinary Clinical Small Animal, v. 33, p. 455-471, 2003. 
FILIPITS, M.; JAEGER, U.; SIMONITSCH, I.; CHIZZALI-BONFADIN, C.; HEINZL, H.;

PIRKER, R. Clinical relevance of the lung resistance protein in diffuse large B-cell lymphomas.

Clinical Cancer Research, v. 6, n. 9, p. 3417-3423, 2000.

GAMST, O.; TRY, K. Determination of serum-phosphate without deproteinization by ultraviolet spectrophotometry of the phosphomolybdic acid complex. Scandinavian Journal of Clinical Laboratory Investigation, v. 40, p. 483-486, 1980.

GINN, P. E. Immunohistochemical detection of P-glycoprotein in formalin-fixed and paraffinembedded normal and neoplastic canine tissues. Veterinary Pathology, v. 33, p. 533-541, 1996.

GOLDIE, J. H.; COLDMAN, A. J. A matthematical model formulating the drug sensitivity of tumours to their spontaneous mutation rate. Cancer Treatment Report, v. 63, p. 1727-1733, 1979.

GOLDSTEIN, L. J.; GALSKI, H.; FOJO, A.; WILLINGHAM, M.; LAI, S. L.; GAZDAR, A.; PIRKER, R.; GREEN, A.; CRIST, W.; BRODEUR, G. M.; LIEBER, M.; COSSMAN, J.; GOTTESMAN, M. M.; PASTAN, I. Expression of a multidrug resistance gene in human cancers. Journal of National Cancer Institute, v. 81, p. 116-124, 1989.

GORNALL, A. G.; BARDAWILL, C. J.; MAXIMA, M. D. Determination of serum proteins by means of biuret reaction. Journal of Biological Chemistry, v. 177, n. 2, p. 751-766, 1949.

GOTTESMAN, M. M.; FOJO, T.; BATES, S. E. Multidrug resistance in cancer: role of ATPdependent transporters. Nature, v. 2, p. 48-58, 2002.

HAHN, K. A.; RICHARDSON, R. C.; HAHN, E. A.; CHRISMAN, C. L. Diagnostic and prognostic importance of chromossomal aberrations identified in 61 dogs with lymphossarcoma. Veterinary Pathology, v. 31, p. 528-540, 1994.

HU, Y.; STEPHEN, A. G.; CAO, J.; TANZER, L. R.; SLAPAK, C. A.; HARRISON, S. D.; DEVANARAYAN, V.; DANTZIG, A. H.; STARLING, J. J.; ROME, L. H.; MOORE, R. E. A very early induction of major vault protein accompanied by increased drug resistance in U-937 cells. Internal Journal of Cancer, v. 97, p. 149-156, 2002.

JAIN, N. C. Schalm's Veterinary Hematology. Philadelphia: Lea \& Febiger, 1986, p.339. 
JILLELLA, A. P.; MURREN, J. R.; KHAWAJA, K. H.; LONGLEY, B. J.; EDELSON, R. L.; COOPER, D. L. P-glycoprotein expression and multidrug resistance in cutaneous T-cell lymphoma. Cancer Investigation, v. 18, n. 7, p. 609-613, 2000.

JULIANO, R. L.; LING, V. A surface glycoprotein modulating drug permeability in chinese hamster ovary cell mutants. Biochemistry and Biophysics Acta, v. 455, n. 1, p. 152-162, 1976.

KANZAKI, A.; TOI, M.; NAKAYAMA, K.; BANDO, H.; MUTOH, M.; UCHIDA, T.; FUKUMOTO, M.; TAKEBAYASHI, Y. The expression of multidrug resistance-related transporters in human breast carcinoma. Japanese Journal of Cancer Research, v. 92, p. 452-458, 2001.

KUWAZURU, Y.; HANADA, S.; FURUKAWA, T.; YOSHIMURA, A.; SUMIZAWA, T.; UTSUNOMIYA, A.; ISHIBASHI, K.; SAITO, T.; UOZUMI, K.; MARUYAMA, M.; ISHIZAWA, M.; ARIMA, T.; AKIYAMA, S. Expression os P-glycoprotein in adult T-cell leukemia cells. Blood, v. 76, p. 2065-2071, 1990.

LAGE, H. ABC-transporters: implications on drug resistance from microorganisms to human cancers. International Journal of Antimicrobial Agents, v. 22, p. 188-199, 2003.

LEE, J. J.; HUGHES, C. S.; FINE, R. L.; PAGE, R. L. P-glycoprotein expression in canine lymphoma: a relevant, intermediate model of multidrug resistance. Cancer, v. 77, n. 9, p. 1892-1898, 1996.

LEONARD, G. D.; FOJO, T.; BATES, S. E. The role of ABC transporters in clinical practice. The Oncologist, v. 8, p. 411-424, 2003.

LIU, Q.; OHSHIMA, K.; KIKUCHI, M. High expression of mdr1 gene and p-glycoprotein in initial and re-biopsy specimens of relapsed B-cell lymphoma. Histopathology, v. 38, p. 209216,2000 .

LOE, D. W.; DEELEY, R. G.; COLE, S. P. C. Biology of the multidrug resistance-associated protein, MRP. European Journal Of Cancer, v. 32, n. 6, p. 945-957, 1996.

LOGGINI, B.; RINALDI, I.; PINGITORE, R.; CRISTOFANI, R.; CASTAGNA, M.; BARACHINI, P. Immunohistochemical study of 49 cutaneous melanomas: p53, PCNA, Bcl-2 expression and multidrug resistance. Tumori, v. 87, p. 179-186, 2001. 
LOWRY, O. H.; ROSENBURG, N. J.; FARR, A. L.; RANDALL, R. J. Protein measurement with the folin phenol reagent. Journal of Biology Chemotherapy, $v$. 193, p. 265-75, 1951.

LUCAS, S. R. R. Avaliação do uso de uma microemulsão lipídica associada ao quimioterápico 1,3-bis(2-cloroetil)-1-nitrosuréia (BCNU) em protocolo terapêutico combinado para o tratamento de cães (canis familiaris, Linnaeus, 1758) com linfoma. 2000. 126 f. Tese (Doutorado) - Faculdade de Medicina, Universidade de São Paulo, São Paulo, 2000.

LUSTGARTEN, J. A.; WENK, R. E. Simple, rapid, kinetic, method for serum creatinine measurement. Clinical Chemistry, v. 18, n.11, p. 1419-1422, 1972.

MACEWEN, E. G.; YOUNG, K. M. Canine lymphoma and lymphoid leukemia. In: WITHROW, S.J.; MacEWEN, E.G. Small Animal Clinical Oncology. 2. ed. Philadelphia, W.B.Saunders, 1996, p. 451-479.

MADEWELL, B. R.; THEILEN, G. H. Haematopoietic neoplasms, sarcomas and related conditions part IV: Canine. In: Lea \& Febiger, 1987, p. 392-407. Veterinary Cancer Therapy. 2. ed. Philadelphia:

MARZOLINE, C.; PAUS, E.; BUCLIN, T.; KIM, R. B. Polymorphisms in human MDR1 ( Pglycoprotein ): Recent advances and clinical relevance. Clinical Pharmacology \& Therapeutics, v. 75, n. 1, p. 13-33, 2004.

MEALEY, K. L.; BARHOUMI, R.; ROGERS, K.; KOCHEVAR, D. T. Doxorrubicin induced expression of P-glycoprotein in a canine osteossarcoma cell line. Cancer Letters, v. 126, p. 187-192, 1998.

MEALEY, K. L.; NORTHRUP, N. C.; BENTJEN, S. A. Increased toxicity of P-glycoproteinsubstrate chemotherapeutic agents in a dog with the MDR1 deletion mutation associated with ivermectin sensitivity. Journal of American Veterinary Medical Association, v. 223, n. 10, p. 1453-1455, 2003.

MICHAYLOVA, V.; LLLKOVA, P. Photometric determination of micro amounts of calcium with Arsenazo III. Analyses Chim Acta, v. 53, p. 194-198, 1971.

MIYOSHI, N.; TOJO, E.; OISHI, A.; FUJIKI, M.; MISUMI, K.; SAKAMOTO, H.; KAMEYAMA, K.; SHIMIZU, T.; YASUDA, N. Immunohistochemical detection of p-glycoprotein (P-gp) and 
multidrug resistance associated protein (MRP) in canine cutaneous mast cell tumors. Journal of Veterinary Medicine Science, v. 64, n. 6, p. 531-533, 2002.

MOORE, A. S.; LEVEILLE, C. R.; REIMANN, K. A.; SHU, H.; ARIAS, I. M. The expression of p-glycoprotein in canine lymphoma and its association with multidrug resistance. Cancer Investigation, v. 13, n. 5, p. 475-479, 1995.

MORAN, E.; CLEARY, I.; LARKIN, A. M.; AMHLAOIBH, R. N.; MASTERSON, A.; SCHEPER, R. J.; IZQUIERDO, M. A.; CENTER, M.; O'SULIVAN, F.; CLYNES, M. Coexpression of MDR-associated markers P-170, MRP and LRP and cytoskeletal proteins, in three resistant variants of the human ovarian carcinoma cell line, OAW42. European Journal of Cancer, v. 33, n. 4, p. 652-660, 1997.

MORRINSON, W. B.; VONDERHAAR, M. A. Cancer in dogs and cats - Medical and surgical management. 2. ed. Indiana: Teton NewMedia, 2002, 645 p.

MOSCOW, J. A.; FAIRCHILD, C. R.; MADDEN, M. J.; RANSOM, D. T.; WIEAND, H. S.; O`BRIEN, E. E.; POPLACK, D. G.; COSSMAN, J.; MYERS, C. E.; COWAN K. H. Expression of anionic glutathione-S-transferase and P-glycoprotein genes in human tissues and tumors. Cancer Research, v. 49, p. 1422-1428, 1989.

MOSSINK, M. H ; VAN ZON, A.; SCHEPER, R. J.; SONNEVELD, P.; WIEMER, E. A. C. Vaults: a ribonucleoprotein particle involved in drug resistance? Oncogene, v.22, p.74587467, 2003.

NATIONAL CANCER INSTITUTE. National Cancer Institute sponsored study of classifications of non-Hodgkin lymphomas: Summary and description of a working formulation for clinical usage. Cancer, v. 49. p. 2112-2135, 1982.

NEFF, M. W.; ROBERTSON, K. R.; WONG, A. K.; SAFRA, N.; BROMAN, K. W.; SLATKIN, M.; MEALEY, K.; PEDERSEN, N. C. Breed distribution and history of canine mdr1-1 1 , a pharmacogenetic mutation that marks the emergence of breeds from collie lineage. PNAS, $\mathrm{V}$. 101, n. 32, p. 11725-11730, 2004.

NIEHANS, G. A.; JASZCZ, W.; BRUNETTO, V.; PERRI, R. T.; GAJL-PECZALSKA, K.; WICK, M. R.; TSURUO, T.; BLOOMFIELD, C. D. Immunohistochemical identification of $p$ glycoprotein in previously untreated, diffuse large cell and immunoblastic lymphomas. Cancer Research, v. 52, p. 3768-3775, 1992. 
OHNO, N.; TANI, A.; UOZUMI, K.; HANADA, S.; FURUKAWA, T.; AKIBA, S.; SUMIZAWA, $\mathrm{T}$. Expression of functional lung resistance-related protein predicts poor outcome in t-cell leukemia. Blood, v. 98, n. 4, p. 1160-1165, 2001.

ONIONS, D. A. A prospective survey of familial canine lymphossarcoma. Journal National Cancer Institute, v. 72, p. 909-912, 1984.

OWEN, L. N.; BOSTOK, D. E.; HALIIWELL, R. E. W. Cell-mediated and humoral immunity in dogs with spontaneous lymphossarcoma. Europe Journal Cancer, v. 11. p. 187-191, 1975.

PENTILLA, I. M.; JOKELA, H. A.; VITALA, A. J. Activities of aspartato and alanino aminotransferase and alkaline phosphatase in sera oh healthy subjects. The Scandinavian Journal of Clinical and Laboratory Investigation, v. 35, n. 3, p. 275-284, 1975.

PERRI, R. T.; LOUIE, S. W.; ESPAR, W. G. Expression of the multidrug resistance (MDR) gene MDR1 in chronic lymphocitic leukemia (CLL) B cells (abstract). Blood, v. 74, p. 198, 1989.

POJE, E.; BIERMAN, P.; DALEY, D.; HALE, C.; WEISENBURGER, D. Expression os Pglycoprotein in B-cell non-Hodgkin's lymphoma. Proclamation of American Association Cancer Research, v. 32, p. 366, 1991.

RAAIJMAKERS, H. G. P.; IZQUIERDO, H. M.; LOKHORST, H. M.; LEEUW, C. D. E.; BELIEN, J. A. M.; BLOEM, A. C.; DEKKER, A. W.; SCHEPER, R. J.; SONNEVELD, P. Lungresistance- related protein expression is a negative predictive factor for response to conventional low but not to intensified dose alkylating chemotherapy in multiple myeloma. Blood, v. 91, n. 3, p. 1029-1036,1998.

RALLIS, T.; KOUTINAS, A.; LEKKAS, S.; PAPADIAMANTIS, J. Lymphoma (malignant lymphoma, lymphossarcoma) in the dog. Journal Small Animal Practice, v. 33, p. 590-596, 1992.

ROSENTHAL, R. C. The treatment of multicentric lymphoma. Veterinary Clinics North American - Small Animal Practice, v. 20, n. 4, p.1093-1104, 1990.

ROSENTHAL, R. C.; MACEWEN, E. G. Treatment of lymphoma in dogs. Review article. Journal American Veterinary Medical Association, v. 196, n. 5, p. 774-781, 1990. 
ROULET, A.; PUEL, O.; GESTA, S.; LEPAGE, J. F.; DRAG, M.; SOLL, M.; ALVINERIE, M.; PINEAU, T. MDR1-deficient genotype collie hypersensitive to the P-glycoprotein substrate ivermectin. European Journal of pharmacology, v. 460, p. 85-91, 2003.

SAUERBREY, A.; VOIGT, A.; WITTIG, S.; HÄFER, R.; ZINTL, F. Messenger RNA analysis of the multidrug resistance related protein (MRP1) and the lung resistance protein (LRP) in de novo and relapsed childhood acute lymphoblastic leukemia. Leukemia and Lymphoma, v. 43, n. 4, p. 875-879, 2002.

SCHNEIDER, J.; GONZALEZ-ROCES, S.; POLLÁN, M.; LUCAS, R.; TEJERINA, A.; MARTIN, M.; ALBA, A. Expression of LRP and MDR1 in locally advanced breast cancer predicts axillary node invasion at the time of rescue mastectomy after induction chemotherapy. Breast Cancer Research, v. 3, n. 3, p. 183-191, 2001.

SIVA, A. C.; RAVAL-FERNANDES, S.; STEPHEN, A. G.; LA FEMINA, M. J.; SCHEPER, R. J. Up-regulation of vaults may be necessary but not sufficient for multidrug resistance.

Int.ernal Journal Cancer, v. 92, p. 195-202, 2001.

STEINGOLD, S. F.; SHARP, N. J.; MCGAHAN, M. C.; HUGHES, C. S.; DUNN, S. E.; PAGE, R. L. Characterization of canine MDR1 mRNA: its abundance in drug resistance cell lines and in vivo. Anticancer Research, n. 18, p. 393-400, 1998.

WEBB, M.; RAPHAEL, C. L.; ASBAHR, H.; ERBER, W. N.; MEYER, B. F. The detection of rhodamine 123 efflux at low levels of drug resistance. British Journal Haematology, v. 93, p. 650-655, 1996.

WITHROW, S. F.; MACEWEN, E. G. Small Animal Clinical Oncology 3. ed. Philadelphia: W.B. Saunders, 2001, 559 p.

TESKE, E. Canine malignant lymphoma: a review and comparision with human nonHodgkin's lymphoma. Veterinary Quarter , v. 16, n. 4, p. 209-219, 1994.

TIFFANY, T. O.; JANSEN, J. M.; BRITO, C. A. Enzymatic kinetic rate and end-point analysis of substrate by use of a GEMSAEC fast analysis. Clinical Chemistry, v. 18, n. 8, p. 829, 1972.

VAN ZON, A.; MOSSINK, M. H.; SCHEPER, R. J.; SONNEVELD, P.; WIEMER, E. A. C. The vault complex. Cellular Molecular Life Science, v. 60, p. 1828-1837, 2003. 
YAMAGUCHI, M.; KITA, K.; MIWA, H.; NISHII, K.; OKA, K.; OHNO, T.; SHIRAKAWA, S.; FUKUMOTO, M. Frequent expression of P-glycoprotein/MDR1 by nasal T-cell lymphoma cells. Cancer, v. 76, n. 11, 1995.

ZHAN, Z.; SANDOR, V. A.; GAMELIN, E.; REGIS, J.; DICKSTEIN, B.; WILSON, W.; FOJO, A. T.; BATES, S. E. Expression of the multidrug resistance-associated protein gene in refractory lymphoma: quantitation by a validated polymerase chain reaction assay. Blood, v. 89, n. 10, p. 3797-3800, 1997. 


\section{APÊNDICE A - EXAMES COMPLEMENTARES}

\section{AVALIAÇÃO HEMATOLÓGICA}

As alterações hematológicas no momento do diagnóstico não foram severas, apenas em 6 casos houve uma diminuição no número de hemáceas, hematócrito e hemoglobina e em 2, uma trombocitopenia relevante (Quadro A.1). A alteração mais comum observada em 6 cães, foi a leucocitose por neutrofilia sem desvio à esquerda (QuadroA.1). 


\begin{tabular}{|c|c|c|c|c|c|c|c|c|c|c|c|c|}
\hline ID & $\mathrm{He}\left(\mathrm{mm}^{3}\right)$ & Ht (\%) & $\mathrm{Hb}(g / d L)$ & VCM (fL) & HCM (pg) & CHCM (\%) & Le $\left(\mathrm{mm}^{3}\right)$ & $N\left(\mathrm{~mm}^{3}\right)$ & $E\left(\mathrm{~mm}^{3}\right)$ & LT $\left(\mathrm{mm}^{3}\right)$ & $M\left(\mathrm{~mm}^{3}\right)$ & Plaq $\left(\mathrm{mm}^{3}\right)$ \\
\hline 01 & 7.6 & 50 & 18.2 & 65.79 & 23.95 & 36.40 & 14.000 & 10.920 & 560 & 2.100 & 420 & 394.000 \\
\hline 02 & 7.0 & 44 & 14.5 & 62.86 & 20.71 & 32.95 & 12.500 & 9.625 & 1.125 & 1.250 & 500 & 186.000 \\
\hline 03 & 3.6 & 25 & 7.9 & 69.44 & 21.94 & 31.60 & 8.200 & 5.248 & 164 & 1.476 & 1.312 & 27.000 \\
\hline 04 & 3.9 & 29 & 10.3 & 74.36 & 26.41 & 35.52 & 7.200 & 3.816 & 216 & 2.316 & 792 & 192.000 \\
\hline 05 & 4.3 & 31 & 10.9 & 72.09 & 25.35 & 35.16 & 5.000 & 4.450 & 0 & 400 & 150 & 65.000 \\
\hline 06 & 5.2 & 38 & 12.4 & 73.08 & 23.85 & 32.63 & 6800 & 5.372 & 204 & 816 & 408 & 236.000 \\
\hline 07 & 5.2 & 34 & 11.7 & 65.38 & 22.50 & 34.41 & 22.500 & 20.700 & 0 & 675 & 1.125 & 334.000 \\
\hline 08 & 4.9 & 36 & 12.1 & 73.47 & 24.69 & 33.61 & 29.900 & 25.116 & 0 & 3.588 & 1.196 & 140.000 \\
\hline 09 & 4.7 & 28 & 8.7 & 59.57 & 18.51 & 31.07 & 26.700 & 24.297 & 801 & 1.335 & 267 & 684.000 \\
\hline 10 & 7.9 & 49 & 17.0 & 62.03 & 21.52 & 34.69 & 11.500 & 8.280 & 920 & 1.380 & 920 & 410.000 \\
\hline 11 & 6.7 & 44 & 15.0 & 65.67 & 22.39 & 34.09 & 23.400 & 20.124 & 234 & 936 & 2.106 & 254.000 \\
\hline 12 & 7.1 & 48 & 16.5 & 67.61 & 23.24 & 34.38 & 30.100 & 27.692 & 0 & 2.408 & 0 & 196.000 \\
\hline 13 & 4.7 & 33 & 11.0 & 70.21 & 23.40 & 33.33 & 18.900 & 16.443 & 189 & 1.701 & 567 & 406.000 \\
\hline 14 & 6.1 & 41 & 13.9 & 67.21 & 22.79 & 33.90 & 14.100 & 11.562 & 846 & 1.128 & 564 & 260.000 \\
\hline 15 & 7.6 & 51 & 17.9 & 67.11 & 23.55 & 35.10 & 21.300 & 19.596 & 0 & 426 & 1.278 & 313.000 \\
\hline
\end{tabular}

Quadro A.1 - Caracterização dos cães com linfoma multicêntrico segundo identificação (ID), No de Hemáceas (He), Hematócrito (Ht), Hemoglobulina $(\mathrm{Hb}), \mathrm{VCM}, \mathrm{HCM}, \mathrm{CHCM}$, No de plaquetas (Plaq), No de Leucócitos (Le), Neutrófilos (N), Eosinófilos (E), Basófilos (B), Linfócitos Típicos (LT), Linfócitos Atípicos (LA), Monócitos (M)ao diagnóstico, atendidos no HOVET-FMVZ/USP, São Paulo - no período de março/03setembro/04 
BIOQUÍMICA SÉRICA

Dentre os cães estudados, apenas um apresentou aumento nas determinações séricas de uréia e creatinina (Quadro A.2).

O achado mais freqüente em relação à função hepática, observado em 10 casos, foi o aumento da atividade sérica da fosfatase alcalina, conforme quadro A.2.

Em todos os casos não existiram alterações significativas, em relação às determinações séricas de cálcio e fósforo (Quadro A.2). 


\begin{tabular}{|l|l|l|l|l|l|l|l|l|}
\hline ID & $\mathbf{U}(\mathbf{m g} / \mathbf{d L})$ & $\mathbf{C}(\mathbf{m g} / \mathbf{d L})$ & $\mathbf{P t}(\mathbf{g} / \mathbf{d L})$ & ALB(g/dL) & ALT(U/L) & FA(U/L) & $\mathbf{C a}(\mathbf{m g} / \mathbf{d L})$ & P(mg/dL) \\
\hline 01 & 30 & 1.2 & 6.0 & 3.5 & 50 & 105 & 8.7 & 4.4 \\
\hline 02 & 23 & 1.1 & 5.3 & 2.7 & 109 & 2.750 & 9.4 & 4.0 \\
\hline 03 & 476 & 2.7 & 6.3 & 1.9 & 67 & 299 & 7.3 & 5.3 \\
\hline 04 & 30 & 1.3 & 6.4 & 2.9 & 170 & 1181 & 9.5 & 4.9 \\
\hline 05 & 13 & 1.0 & 5.0 & 2.9 & 158 & 2.700 & 8.4 & 3.4 \\
\hline 06 & 29 & 1.1 & 5.8 & 2.2 & 73 & 213 & 10.2 & 4.8 \\
\hline 07 & 17 & 1.0 & 5.4 & 2.7 & 55 & 150 & 9.0 & 3.8 \\
\hline 08 & 47 & 1.5 & 5.8 & 2.7 & 93 & 976 & 9.6 & 5.6 \\
\hline 09 & 36 & 1.4 & 5.6 & 2.9 & 97 & 253 & 9.7 & 6.0 \\
\hline 10 & 23 & 1.4 & 6.3 & 3.2 & 31 & 221 & 9.6 & 4.2 \\
\hline 11 & 18 & 0.93 & 7.5 & 3.2 & 62 & 701 & 9.8 & 5.8 \\
\hline 12 & 23 & 1.2 & 5.8 & 3.5 & 33 & 250 & 9.7 & 3.1 \\
\hline 13 & 36 & 1.3 & 5.2 & 2.6 & 17 & 169 & 9.0 & 3.4 \\
\hline 14 & 30 & 1.3 & 6.2 & 3.3 & 34 & 65 & 10.5 & 3.7 \\
\hline 15 & 16 & 1.3 & 6.1 & 2.8 & 58 & 132 & 9.9 & 2.2 \\
\hline
\end{tabular}

Quadro A.2 - Caracterização dos cães com linfoma multicêntrico segundo identificação (ID), Uréia $(U)$, Creatinina $(C)$, Proteínas Totais $(P t)$, Albumina (ALB), Alanina Aminotransferase (ALT), Fosfatase Alcalina (FA), Cálcio (Ca) e Fósforo (P), ao diagnóstico, atendidos no HOVET-FMVZ/USP, São Paulo - no período de março/03-setembro/04 


\section{URINA I}

Em relação ao exame de urina tipo I, a presença de bactérias foi o achado mais comum, seguido pela presença de células de pelve renal (Quadro A.3).

\begin{tabular}{|l|l|l|l|l|l|l|}
\hline ID & Odor & Aspecto & Cor & $\mathbf{p H}$ & Densidade & Observações \\
\hline 01 & Aliáceo & Límpido & Amarelo palha & 8.5 & 1.023 & Bactérias (+) \\
\hline 02 & Aliáceo & Turvo & Amarelo ouro & 6.0 & 1.045 & Bactérias (+) \\
\hline 03 & Aliáceo & Turvo & Amarelo ouro & 7.0 & 1.035 & Bactérias +++ \\
\hline 04 & Aliáceo & Turvo & Amarelo ouro & 5.0 & 1.036 & Bactérias ++ \\
\hline 05 & Pútrido & Turvo & Amarelo ouro & 6.0 & 1.027 & Bactérias+++ \\
\hline 06 & Aliáceo & Límpido & Amarelo ouro & 6.0 & 1.036 & ndn \\
\hline 07 & Aliáceo & Turvo & Amarelo ouro & 8.0 & 1.042 & Bactérias +++ \\
\hline 08 & Aliáceo & Turvo & Amarelo ouro & 6.0 & $>1.050$ & Bactérias +++ \\
\hline 09 & Aliáceo & Turvo & Amarelo ouro & 8.0 & 1.015 & ndn \\
\hline 10 & Aliáceo & Turvo & Amarelo ouro & 7.5 & 1.044 & Bactérias (+) \\
\hline 11 & Alíáceo & Turvo & Amarelo ouro & 8.0 & 1.026 & Céls. pelve renal \\
\hline 12 & Alí́ceo & Turvo & Amarelo ouro & 7.0 & $>1.050$ & Bactérias (+) \\
\hline 13 & Alíáceo & Turvo & Amarelo ouro & 7.0 & 1.042 & Céls. pelve renal \\
\hline 14 & Aliáceo & Límpido & Amarelo ouro & 7.0 & 1.020 & Bactérias (+) \\
\hline 15 & Aliáceo & Turvo & Amarelo ouro & 5.5 & 1.036 & Bactérias (+) \\
\hline
\end{tabular}

Legenda - ndn: nada digno de nota

Quadro A.3- Cães com linfoma multicêntrico segundo identificação (ID), Odor, Aspecto, Cor, pH, Densidade e Observações encontradas na urina, ao diagnóstico, atendidos no HOVET-FMVZ/USP, São Paulo - no período de março/03setembro/04 


\section{EXAMES DE IMAGEM}

As alterações mais freqüentemente observadas pela radiografia torácica foram a opacificação intersticial difusa em campos pulmonares e o aumento nas dimensões dos linfonodos traqueobrônquicos, mediastino-craniais e esternais. Dois casos apresentaram efusão pleural (Quadro A.4).

As alterações ultra-sonográficas mais comuns foram alterações nas dimensões, ecogenicidade e presença de nódulos em fígado e/ou baço. Notou-se também aumento dos linfonodos mesentéricos, ilíacos, peri-esplênicos e perihepáticos (Quadro A.4). 


\begin{tabular}{|c|c|c|}
\hline ID & $\mathbf{R X}$ & US \\
\hline 01 & Ndn & Ndn \\
\hline 02 & $\begin{array}{l}\text { Opacificação intersticial } \\
\text { difusa em campos } \\
\text { pulmonares com } \\
\text { evidenciação de paredes } \\
\text { bronquiais. }\end{array}$ & $\begin{array}{l}\text { Fígado: aumento de tamanho } \\
\text { Baço: aumento de tamanho, parênquima heterogêneo } \\
\text { Linfoadenomegalia: peri-hepáticos, peri-esplênicos, mesentéricos e } \\
\text { gástricos. }\end{array}$ \\
\hline 03 & $\mathrm{Ndn}$ & $\begin{array}{l}\text { Fígado: ndn } \\
\text { Baço: aumentado, } 1 \text { nódulo hipoecóico em corpo 0,9cm. }\end{array}$ \\
\hline 04 & $\begin{array}{l}\text { Opacificação intersticial } \\
\text { difusa em campos } \\
\text { pulmonares com } \\
\text { espessamento de paredes } \\
\text { brônquicas. }\end{array}$ & $\begin{array}{l}\text { Fígado: aumento de tamanho } \\
\text { Baço: aumento de tamanho, pontos hipoecóicos entremeados } \\
\text { Aumento dos linfonodos peri-hepáticos, mesentéricos e ilíacos mediais. }\end{array}$ \\
\hline 05 & $\begin{array}{l}\text { Efusão pleural , } \\
\text { pneumotórax e } \\
\text { aumento dos linfonodos } \\
\text { mediastino-craniais. }\end{array}$ & $\begin{array}{l}\text { Fígado: aumento de tamanho, ecogenicidade difusamente elevada } \\
\text { Baço: severamente aumentado, múltiplos nódulos hipoecóicos } \\
\text { Aumento de vários linfonodos mesentéricos } \\
\text { Segmento de alça intestinal com espessamento, plicada e irregular, com } \\
\text { discreta perda de camadas }(0,96 \mathrm{~cm}) \text {. }\end{array}$ \\
\hline 06 & Efusão pleural & $\begin{array}{l}\text { Fígado: aumento de tamanho, ecogenicidade difusamente elevada } \\
\text { Baço: levemente aumentado, múltiplos nódulos hipoecóicos } \\
\text { Aumento de vários linfonodos mesentéricos. }\end{array}$ \\
\hline 07 & $\begin{array}{l}\text { Aumento de linfonodo } \\
\text { traqueobrônquico, } \\
\text { mediastino- cranial e } \\
\text { esternal. }\end{array}$ & $\begin{array}{l}\text { Baço: levemente aumentado, ecogenicidade discretamente heterogênea } \\
\text { Fígado: acentuadamente aumentado de tamanho, ecogenicidade diminuída } \\
\text { Aumento de vários linfonodos mesentéricos. }\end{array}$ \\
\hline 08 & $\begin{array}{l}\text { Aumento de linfonodo } \\
\text { mediastino-cranial. }\end{array}$ & $\begin{array}{l}\text { Fígado: aumentado de tamanho, contornos arredondados e ecogenicidade } \\
\text { difusamente heterogênea } \\
\text { Baço: severamente aumentado de tamanho, contornos irregulares, } \\
\text { ecogenecidade heterogênea } \\
\text { Aumento de vários linfonodos mesentéricos. }\end{array}$ \\
\hline 09 & $\mathrm{Ndn}$ & Ndn \\
\hline 10 & $\begin{array}{l}\text { Leve aumento linfonodo } \\
\text { esternal e mediastino- } \\
\text { cranial. }\end{array}$ & $\begin{array}{l}\text { Fígado: ecogenecidade levemente aumentada } \\
\text { Baço: aumento de tamanho, ecogenecidade levemente heterogênea c/ } \\
\text { nódulos hipoecóicos } \\
\text { Leve aumento linfonodos peri-esplênicos e ilíacos. }\end{array}$ \\
\hline 11 & Ndn & $\begin{array}{l}\text { Fígado: aumento de tamanho, leve aumento de ecogenecidade. } \\
\text { Baço: leve aumento de tamanho, contorno levemente irregular, múltiplos } \\
\text { nódulos hipo/anecogênicos entremeados pelo parênquima } \\
\text { Discreto aumento de linfonodo Ilíaco medial esquerdo e mesentérico. }\end{array}$ \\
\hline 12 & $\mathrm{Ndn}$ & $\begin{array}{l}\text { Fígado: levemente aumentado de tamanho, contornos levemente } \\
\text { irregulares, com múltiplos nódulos hipo/anecóicos até 0,5cm } \\
\text { Leve aumento linfonodos ilíacos e mesentéricos craniais, levemente } \\
\text { heterogêneos e hipoecóicos. }\end{array}$ \\
\hline 13 & $\begin{array}{l}\text { Acentuado aumento de } \\
\text { linfonodos traqueo- } \\
\text { brônquicos, mediastino- } \\
\text { cranial e esternal } \\
\text { Opacificação intersticial, } \\
\text { intensa e difusa em campos } \\
\text { pulmonares. }\end{array}$ & $\begin{array}{l}\text { Fígado: aumentado de tamanho, ecogenecidade discretamente reduzida } \\
\text { Baço: leve aumento de tamanho, ecogenecidade levemente heterogênea, } \\
\text { múltiplos nódulos hipoecóicos entremeados no parênquima } \\
\text { Leve aumento de linfonodos peri-hepáticos e ilíacos mediais. }\end{array}$ \\
\hline 14 & $\begin{array}{l}\text { Aumento de linfonodo } \\
\text { esternal. }\end{array}$ & $\begin{array}{l}\text { Fígado: ndn } \\
\text { Baço: aumentado de tamanho, ecogenecidade difusamente heterogênea } \\
\text { Moderado aumento dos linfonodos peri-hepáticos, mesentéricos e ilíacos } \\
\text { mediais. }\end{array}$ \\
\hline 15 & Ndn & Baço: ecogenecidade difusamente heterogênea, com nódulos \\
\hline
\end{tabular}

Legenda: ndn - nada digno de nota

Quadro A.4 - Caracterização dos cães com linfoma multicêntrico segundo identificação (ID), radiografia torácica (RX) e ultra-sonografia abdominal (US), atendidos no HOVET-FMVZ/USP, ao diagnóstico, São Paulo - no período de março/03 a setembro/04 